\title{
AVALIAÇÃO DE MÉTODOS PARA ENUMERAÇÃO DE MICRORGANISMOS AERÓBIOS MESÓFILOS E COLIFORMES EM LEITE CRU
}

\author{
GIOVANA VERGINIA BARANCELLI \\ Médico Veterinário
}

Orientador: Prof. Dr. CLÁUDIO RÖSA GALLO

Dissertação apresentada à Escola Superior de Agricultura "Luiz de Queiroz", Universidade de São Paulo, para obtenção do título de Mestre em Ciências, Área de Concentração: Ciência e Tecnologia de Alimentos.

PIRACICABA

Estado de São Paulo - Brasil

Setembro - 2002 


\section{Dados Internacionais de Catalogação na Publicaçāo (CIP) DIVISÃO DE BIBLIOTECA E DOCUMENTAÇÃO - ESALQ/USP}

\section{Barancelli, Giovana Verginia}

Avaliaçāo de métodos para enumeraçāo de microrganismos aerobios mesófilos e coliformes em leite cru / Giovana Verginia Barancelli. - - Piracicaba, 2002.

87 p. : il.

Dissertaçāo (mestrado) - Escola Superior de Agricultura Luiz de Queiroz, 2002. Bibliografia.

1. Análise de alimentos 2. Bactérias aeróbias 3. Leite 4. Microbiologia de alimentos I. Título

CDD 637.1277

\section{Termitida a copla total ou parcial deste docunento, desde que citada a fonte - $\mathbf{0}$ autor"}


Ao meu pai, pelo exemplo de vida que me deixou A minha mãe Ao Luís, Dedico 


\section{AGRADECIMENTOS}

Ao Professor Dr. Cláudio Rosa Gallo pela orientação, pelos ensinamentos e por toda atenção dedicada.

Ao Professor Dr. Antônio Joaquim de Oliveira pelo apoio e importante contribuição neste trabalho.

À Professora Dra. Sônia De Stefano Piedade pela orientação nas análises estatísticas.

Aos Professores Dr. André R. Alcarde, Dra. Marília Oetterer e Dra. Silene Bruder Sarmento, da banca do Exame de Qualificação, pelas sugestões apresentadas.

Ao Professor Dr. Ernani Porto pela paciência de indicar caminhos e passar conhecimentos.

Ao corpo docente e funcionários do Departamento de Agroindústria Alimentos e Nutrição da ESALQ/USP.

À Beatriz Giongo e à Midiam Gustinelli pela ajuda na biblioteca. À Vilma Sarto Zeferino, do serviço de "comutação", pela disposição em atender com tanta eficiência às solicitações. À bibliotecária Ligiana Clemente pelas correções das referências bibliográficas.

À CAPES pela concessão da bolsa de estudo.

À amiga Flávia pela colaboração na fase das análises; Fabiana e Romilda, pela convivência sempre tão agradável.

Ao Luís pelo incentivo constante e exemplo de organização e persistência.

Ao meu irmão Fábio que, mesmo de longe, me auxilia muito.

Agradeço a Deus por ter concluído este trabalho. 


\section{SUMÁRIO}

Página

LISTA DE FIGURAS........................................................................ vii

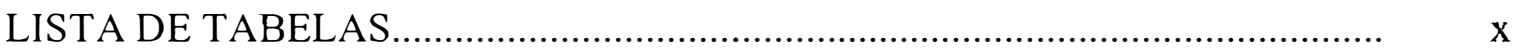

LISTA DE QUADROS......................................................................

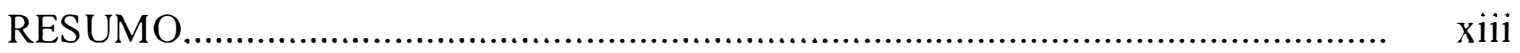

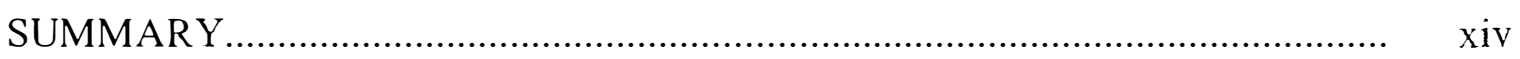

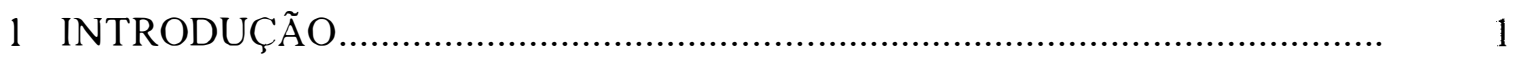

1.2 Objetivos............................................................................... 2

2 REVISÃO DE LITERATURA............................................................... 3

2.1 Considerações gerais.............................................................. 3

2.2 Métodos de análise microbiológica................................................ 4

2.2.1 Métodos convencionais de análise microbiológica............................ 5

2.2.2 Métodos rápidos de análise microbiológica.................................... 7

2.2.2.1 Placas Petrifilm ${ }^{\circledR}$ para contagem de aeróbios mesófilos (Petrifilm ${ }^{\circledR} \mathrm{AC}$ ) 8

2.2.2.2 Placas Petrifilm ${ }^{\circledR}$ para contagem de coliformes totais com

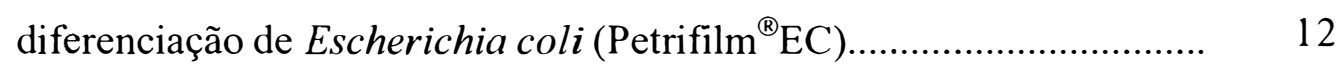

2.2.2.3 SimPlate ${ }^{\circledR}$ para contagem total de aeróbios mesófilos (SimPlate ${ }^{\circledR}$ TPC) $\quad 14$

2.2.2.4 SimPlate ${ }^{\circledR}$ para coliformes totais e Escherichia coli (SimPlate $\left.{ }^{\circledR} \mathrm{CEc}\right) \ldots \quad 16$

2.3 Aspectos relativos a critérios microbiológicos e aprovações por órgãos oficiais.................................................................................. 17

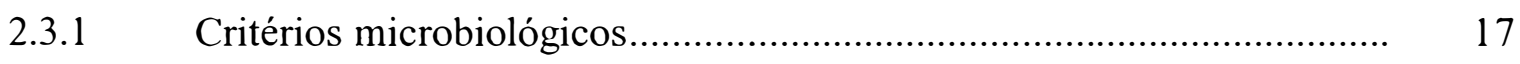

2.3.2 Aprovações por órgãos oficiais...................................................... 19

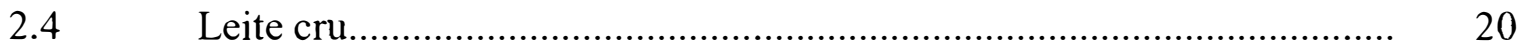




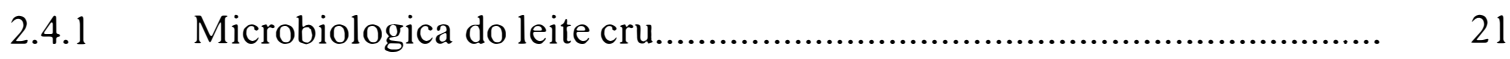

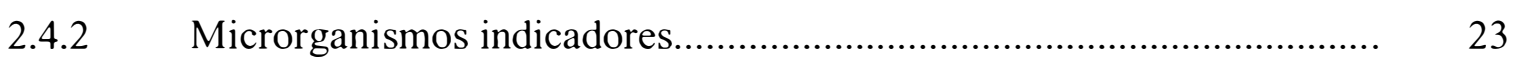

2.4.2.1 Microrganismos aeróbios mesófillos.................................................. 23

2.4.2.2 Grupo coliforme.................................................................. 25

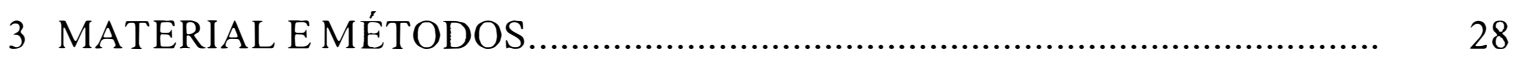

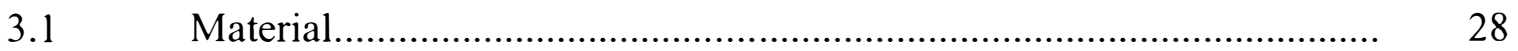

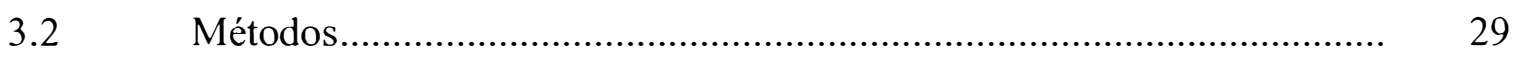

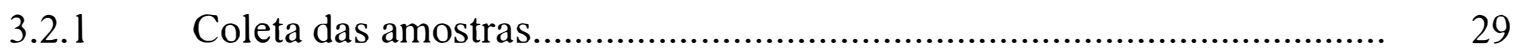

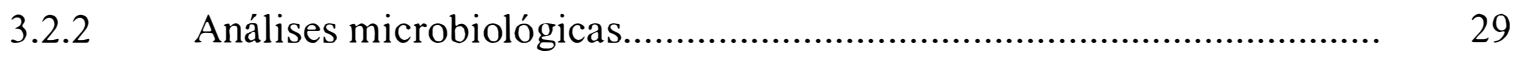

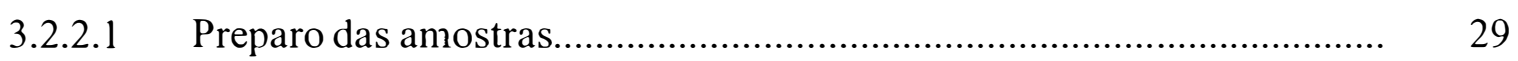

3.2.2.2 Contagem total de microrganismos aeróbios mesófilos pelo método convencional..................................................................... 30

3.2.2.3 Contagem total de microrganismos aeróbios mesófilos em

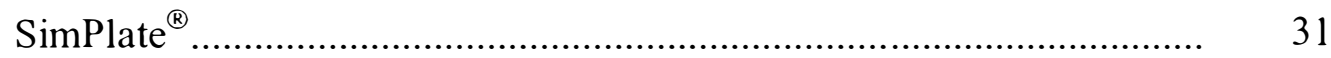

3.2.2.4 Contagem total de microrganismos aeróbios mesófilos em

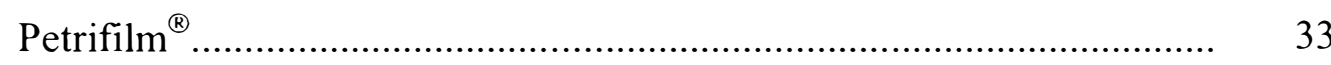

3.2.2.5 Enumeração de coliformes totais pela técnica dos tubos múltiplos

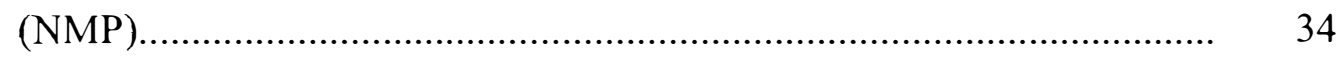

3.2.2.5.1 Identificação e cálculo do NMP de Escherichia coli............................. 35

3.2.2.6 Contagem de coliformes totais e Escherichia coli em Petrifilm ${ }^{\circledR}$ EC...... $\quad 38$

3.2.2.7 Contagem de coliformes totais e Escherichia coli em

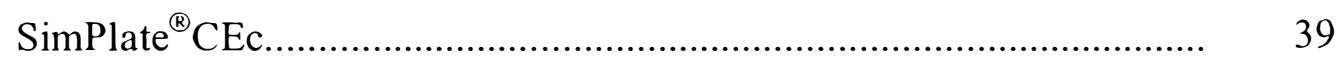

Análise estatística.................................................................. 40

4 RESULTADOS E DISCUSSÃO

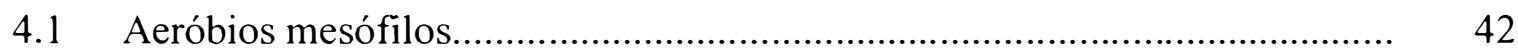

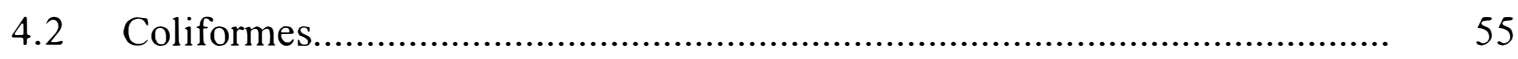

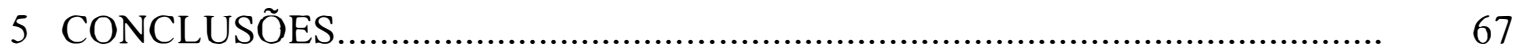

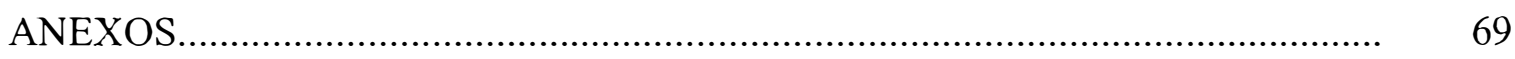

REFERÊNCIAS BIBLIOGRÁFICAS........................................................... 75 


\section{LISTA DE FIGURAS}

Página

1 (a) Placa Petrifilm ${ }^{\circledR} \mathrm{AC}$; (b) Inoculação da amostra na placa; (c) Placa Petrifilm ${ }^{\circledR} \mathrm{AC}$ após o período de incubação.

2 Placa Petrifilm ${ }^{\circledR}$ EC

3 Placa SimPlate ${ }^{\circledR} \mathrm{TPC}$, vista sob luz ultravioleta, a $365 \mathrm{~nm}$.

4 Placa SimPlate ${ }^{\circledR} \mathrm{CEc}$

5 Esquema para diluição das amostras.

6 Esquema da análise de aeróbios mesófilos pelo método convencional.

7 Representação do procedimento analítico em SimPlate ${ }^{\circledR} \mathrm{TPC}$

8 Esquema do procedimento analítico em Petrifilm ${ }^{\circledR}$ AC para a contagem total de microrganismos aeróbios mesófilos.

9 Esquema do procedimento analítico de coliformes pelo método convencional 
10 Esquema analítico para coliformes totais e E. coli em Petrifilm ${ }^{\circledR}$ EC.............. 38

11 Dispersão dos resultados das contagens de microrganismos aeróbios mesófilos em leite cru, obtidos pelos métodos de contagem em placas com PCA e Petrifilm ${ }^{\circledR} \mathrm{AC}$

12 Dispersão dos resultados das contagens de microrganismos aeróbios mesófilos em leite cru, obtidos pelos métodos de contagem em placas em PCA e SimPlate ${ }^{\circledR}$ TPC

13 Dispersão dos resultados das contagens de microrganismos aeróbios mesófilos em leite cru, obtidos em Petrifilm ${ }^{\circledR} \mathrm{AC}$ e SimPlate ${ }^{\circledR} \mathrm{TPC}$

14 Comparação entre as médias obtidas nas contagens de aeróbios mesófilos pelos métodos convencional (PCA), Petrifilm ${ }^{\circledR}$ AC e SimPlate ${ }^{\circledR} \mathrm{TPC}$

15 Dispersão dos resultados das contagens de coliformes totais em leite cru obtidos pelos métodos NMP (tubos múltiplos) e Petrifilm ${ }^{\circledR}$ EC

16 Dispersão dos resultados das contagens de coliformes totais em leite cru obtidos pelos métodos NMP (tubos múltiplos) e SimPlate ${ }^{\circledR} \mathrm{CEc}$

17 Dispersão dos resultados das contagens de coliformes totais em leite cru obtidos pelos métodos SimPlate ${ }^{\circledR}$ CEc e Petrifilm ${ }^{\circledR}$ EC 
18 Comparação entre as médias obtidas nas contagens de coliformes totais pelos métodos dos tubos múltiplos (NMP), Petrifilm ${ }^{\circledR} \mathrm{EC} \quad \mathrm{e}$

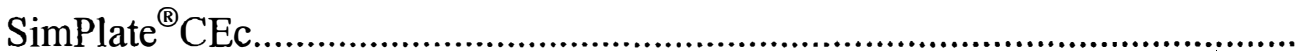




\section{LISTA DE TABELAS}

Página

1 Dados obtidos na contagem total de aeróbios mesófilos em leite cru pelos métodos convencional (PCA), Petrifilm ${ }^{\circledR}$ AC e SimPlate ${ }^{\circledR}$ TPC e logaritmo dos dados.

2 Resumo das comparações estatísticas entre os métodos de plaqueamento em profundidade (PCA), Petrifilm ${ }^{\circledR} \mathrm{AC}$ e SimPlate ${ }^{\circledR} \mathrm{TPC}$ para contagem de mesófilos em leite cru

3 Dados obtidos na contagem de coliformes totais pelos métodos convencional (NMP - tubos múltiplos), Petrifilm ${ }^{\circledR}$ EC e SimPlate ${ }^{\circledR}$ CEc e logaritmo dos dados

4 Resumo das comparações estatísticas entre os métodos NMP (tubos múltiplos), Petrifilm ${ }^{\circledR}$ EC e SimPlate ${ }^{\circledR}$ CEc para contagem de coliformes totais em leite cru.

5 Dados obtidos na contagem de coliformes fecais e Escherichia coli pelos métodos convencional (NMP - tubos múltiplos), Petrifilm ${ }^{\circledR} \mathrm{EC} \quad \mathrm{e}$ SimPlate ${ }^{\circledR}$ CEc. 
7 Análise de Variância e Teste F para contagem de coliformes totais................ 


\section{LISTA DE QUADROS}

Página

1 Padrões microbiológicos para o leite cru

2 Método SimPlate ${ }^{\circledR}$ de alcance normal para determinação do número mais provável de microrganismos (NMP) por grama ou mililitro de alimento.

3 Número mais provável para várias combinações de resultados positivos, quando três tubos são usados por diluição (inoculação de 1,0; 0,1 e 0,01g ou $\mathrm{mL}$ de amostra 


\title{
AVALIAÇÃO DE MÉTODOS PARA ENUMERAÇÃO DE MICRORGANISMOS AERÓBIOS MESÓFILOS E COLIFORMES EM LEITE CRU
}

\author{
Autora: GIOVANA VERGINIA BARANCELLI \\ Orientador: Prof. CLÁUDIO ROSA GALLO
}

\section{RESUMO}

Os métodos rápidos de análise microbiológica de alimentos apresentam vantagens sobre os métodos convencionais no que se refere à simplificação do trabalho no laboratório, redução de tempo na obtenção de resultados e diminuição de custos das análises. Nos últimos anos, têm sido desenvolvida uma série de métodos rápidos para análises microbiológicas. Especificamente para a indústria de laticínios, a evolução desses métodos visa atender às necessidades, com respeito: à aquisição de leite cru, ao controle de processamento, à avaliação do produto final, ao controle de armazenamento e distribuição dos produtos. Entre as diversas tecnologias alternativas estão os sistemas Petrifilm $^{\circledR}$ e SimPlate $^{\circledR}$. Neste estudo foram feitas avaliações das placas Petrifilm ${ }^{\circledR}$ e SimPlate ${ }^{\circledR}$ para contagem total de bactérias aeróbias mesófilas e coliformes, em comparação com os métodos convencionais de análise de leite cru. A análise de regressão simples dos dados mostrou forte correlação entre os métodos, tanto para a enumeração de bactérias aeróbias mesófilas $(r \geq 0,97)$ como para coliformes $(r \geq 0,95)$. 


\title{
EVALUATION OF METHODS FOR DETERMINING AEROBIC MICROORGANISMS AND COLIFORM COUNTS IN RAW MILK
}

\author{
Author: GIOVANA VERGINIA BARANCELLI \\ Adviser: Prof. CLÁUDIO ROSA GALLO
}

\section{SUMMARY}

Microbiological rapid methods of food show advantages when compared with the conventional tests regarding work simplification in the laboratory, time reduction to obtain results and cost reduction of analysis. Over the last years, several rapid tests for microbiological analysis have been developed. To the dairy industry, the development of these methods aims to meet the needs, concerning: raw milk acquisition, processing control, final products evaluation, storage control and products distribution. Among alternative technologies developed are the Petrifilm ${ }^{\mathrm{TM}}$ and SimPlate ${ }^{\mathrm{TM}}$. In this study, evaluations of the Petrifilm ${ }^{\mathrm{TM}}$ and SimPlate ${ }^{\mathrm{TM}}$ were made in order to determine the total plate count and coliform group count, compared to conventional methods for raw milk analysis. Simple regression analysis of the data showed strong correlation among the methods for determining the number of aerobic bacteria $(r \geq 0,97)$ as well as for coliform count ( $r \geq 0,95)$. 


\section{INTRODUÇÃO}

A busca por máximo rendimento na produção de produtos lácteos e a preferência por produtos de qualidade e tempo de vida útil prolongado têm aumentado a necessidade de aquisição de leite cru de alta qualidade pela indústria. Além da exigência dos consumidores com relação à qualidade dos alimentos, o estabelecimento de normas e padrões oficiais têm levado as indústrias a implantar sistemas que garantam a qualidade de seus produtos.

A qualidade de um alimento pode ser medida em termos sensoriais, de composição química, física e microbiológica, tanto qualitativa como quantitativamente (Hayes, 1993). Dependendo do grau de evolução tecnológica da região considerada, os aspectos de qualidade, de um modo amplo, adquirem maior importância do que simplesmente os aspectos higiênico-sanitários. Porém, em alimentos, o fator de natureza biológica, particularmente de origem microbiana, sempre ocupa lugar de destaque.

No caso do leite, a qualidade está vinculada ao seu "flavor", composição fǐsicoquímica, ponto de congelamento, ausência de antibióticos e outros contaminantes, contagem de células somáticas e de sedimentos, tamanho da população microbiana e tipos de microrganismos presentes. Para o leite cru, a enumeração de microrganismos é um dos critérios usados para avaliar se a matéria-prima atende aos padrões da legislação ou aos critérios microbiológicos utilizados pela indústria. Nos últimos anos, um número crescente de laticínios e cooperativas vêm remunerando o produtor de leite de acordo com a qualidade da matéria-prima fornecida à indústria.

Para a avaliação do aspecto sanitário dos alimentos, nas duas últimas décadas, tem sido desenvolvida uma série de métodos rápidos de análise microbiológica que visam reduzir o tempo de análise no laboratório e aumentar a produtividade do trabalho 
realizado, quando comparados aos métodos tradicionais, significando menor retenção do produto na indústria.

Os métodos não convencionais para enumerar patógenos específicos ou grupos de microrganismos indicadores são largamente utilizados, muitos deles aprovados pela Association of Official Analytical Chemists (AOAC) (Sharpe, 1995), considerado em nosso país como o mais importante centro de referência. Entre as tecnologias alternativas para determinação da contagem de microrganismos em alimentos estão os sistemas Petrifilm ${ }^{\circledR}$ e SimPlate ${ }^{\circledR}$.

Franco (1994) chama atenção para a vasta literatura científica internacional relativa à utilização do Petrifilm $^{\circledR}$, para vários tipos de alimentos, e destaca a importância de ser estudada a adequacidade desse sistema nas condições de trabalho e nos alimentos brasileiros. Quanto ao SimPlate ${ }^{\circledR}$, método desenvolvido recentemente, existem poucos trabalhos na literatura especializada comparando a sua performance com os métodos convencionais, tanto para a contagem total de aeróbios mesófilos como para coliformes.

\subsection{Objetivos}

O presente trabalho teve por objetivos:

Avaliar os métodos Petrifilm ${ }^{\circledR}$ AC e SimPlate ${ }^{\circledR}$ TPC em comparação com o método convencional de contagem em placas de Petri para enumeração de microrganismos aeróbios mesófilos em leite cru.

Avaliar os métodos Petrifilm ${ }^{\circledR}$ EC e SimPlate ${ }^{\circledR}$ CEc em comparação com o método convencional (NMP- tubos múltiplos) para enumeração de bactérias do grupo coliforme em leite cru. 


\section{REVISÃO DE LITERATURA}

\subsection{Considerações gerais}

A avaliação da contaminação microbiana dos alimentos é um dos parâmetros mais importantes para verificar se o alimento terá a vida útil pretendida, se oferece risco à saúde do consumidor e se atende aos padrões de qualidade e especificações microbiológicas (Franco, 1996a).

Os métodos clássicos de análise microbiológica apresentam inconvenientes como tempo longo para a execução das análises e exigem espaço no laboratório. Além disso, alguns são demasiadamente trabalhosos, o que pode colocar em risco a exatidão com que a análise é efetuada. Os métodos rápidos têm como principais objetivos a redução dos custos de análise e do tempo envolvido na obtenção de resultados, além da simplificação do trabalho laboratorial (Franco et al.,1992).

No caso de produtos lácteos, apesar do avanço tecnológico e automação no processamento e análise dos componentes deste grupo de alimento, a parte de testes microbiológicos na indústria empregava largamente, em 1993, métodos de plaqueamentos tradicionais, estimativas pela contagem do número mais provável (NMP) e testes empíricos como a redução do azul de metileno ou resazurina (Vasavada et al., 1993). Franco (1998) informa que até há bem pouco tempo, a análise microbiológica de leite nas indústrias era realizada pelos métodos desenvolvidos no início do século. O desenvolvimento tecnológico no setor alimentício, a implementação cada vez mais freqüente dos conceitos de Análise de Perigos e Pontos Críticos de Controle (HACCP) e de Boas Práticas de Fabricação (BPF), além da ampliação dos conhecimentos sobre os microrganismos importantes em alimentos, indicam a necessidade de substituição dos 
métodos convencionais por métodos alternativos mais modernos (Franco, 1998). Nos sistemas modernos de gerenciamento de laboratórios, qualquer recurso que melhore a eficiência relativa às análises é muito valorizado.

Os métodos rápidos também são justificados do ponto de vista de redução de gastos decorrentes de testes de rotina microbiológica, como nos programas de HACCP. Os novos métodos, apesar de inicialmente poderem ter custos relativamente mais altos, podem tomar-se econômicos a longo prazo (Vasavada et al, 1993). Sobre esse aspecto, Beloti (2000) comenta que a maior praticidade conferida pelos métodos alternativos permite uma otimização dos recursos físicos e humanos alocados para o controle de qualidade, resultando na diminuição dos custos por análise. Sharpe (1995) complementa que a regularidade do uso de "kits" comerciais leva a uma economia de meios de cultivo, material de laboratório e diminuição do trabalho.

Especificamente para a indústria de laticínios, a evolução dos métodos de análise microbiológica visa atender às necessidades, com respeito: à aquisição de leite cru, ao controle de processamento, à avaliação do produto final, ao controle de armazenamento e distribuição (Vasavada et al., 1993).

Para o leite, Beloti (2000) considera que a ampla utilização dos métodos alternativos depende da comprovação da sua eficiência para avaliação microbiológica do leite brasileiro, levando-se em conta suas características de produção, sua microbiota e, inclusive, os recursos humanos disponíveis. No caso do Petrifilm, usado para leite pasteurizado, Beloti et al. (2000) afïrmam que há uma relação direta entre a qualidade do leite e o seu desempenho.

\subsection{Métodos de análise microbiológica}

Os métodos para avaliação do conteúdo bacteriano do leite podem ser classificados em duas categorias. A primeira é dos métodos diretos, que são baseados na contagem do número de bactérias ou na contagem de colônias após crescimento em meio nutritivo, ou contagem de células coradas no microscópio. A segunda categoria é a 
de métodos indiretos, baseados na medida de atividade metabólica ou produtos da atividade metabólica (O'Toole, 1983).

\subsubsection{Métodos convencionais de análise microbiológica}

Os métodos convencionais utilizados na avaliação da contaminação microbiológica são descritos em textos considerados de referência, sendo os mais importantes: o Bacteriological Analytical Manual publicado em conjunto pela United States Food and Drug Administration (FDA) e AOAC International, o Compendium of Methods for the Microbiological Examination of Foods, o Standard Methods for the Examination of Dairy Products (SMEDP) e o Microorganisms in Foods - Their Significance and Methods of Enumeration publicado pela International Commission on Microbiological Specifications (ICMSF). Além desses, existem os métodos recomendados por outras associações como a International Organization for Standardization (ISO), a International Dairy Federation (IDF) e outras. Esses textos são, de modo geral, aceitos internacionalmente, inclusive no Brasil (Franco, 1996b), onde as normas da Associação Brasileira de Normas Técnicas (ABNT) também são consideradas de referência.

Em relação a qualquer método novo, os convencionais apresentam a vantagem de serem utilizados há longo tempo e reconhecidos como oficiais (Chain \& Fung, 1991). Por outro lado, têm desvantagens, sendo as mais evidentes aquelas relacionadas com tempo longo para obtenção de resultados, com o volume de trabalho, tempo envolvido na execução e com o custo de vidraria e equipamentos de laboratório necessários (Franco, 1994).

Os métodos convencionais para se estimar o número de microrganismos viáveis em alimentos dividem-se em dois grandes grupos: aqueles em que se contam as colônias individuais formadas e o resultado é expresso em unidades formadoras de colônias (UFC) - por grama ou mililitro do produto, e aqueles em que o número de microrganismos é estimado pela técnica do número mais provável - NMP. Na primeira 
técnica, a semeadura é feita em meio sólido, em placas, e, na segunda, em meio líquido, em tubos.

A contagem de microrganismos em placas de Petri é o método convencional mais utilizado para enumeração de microrganismos em função da precisão e versatilidade. Vários grupos de microrganismos diferentes podem ser quantificados dessa maneira, variando-se apenas o meio de cultivo ou as condições da incubação (Silva et al., 1996; Tortora et al., 2000). O método convencional de contagem de microrganismos em placas é um método geral utilizado para contagem de grandes grupos microbianos, como os aeróbios mesófilos. O princípio do método baseia-se na premissa de que cada célula microbiana presente em uma amostra irá formar uma colônia visível isolada, quando fixada em um meio de cultivo sólido adequado (Silva et al., 1997). Cada colônia que aparece no ágar pode ser proveniente de uma célula única ou de um grupo de microrganismos, assim, cada colônia deve ser referida como uma unidade formadora de colônia (UFC) (Swanson et al., 1992).

Do ponto de vista de precisão dos resultados, tanto o plaqueamento em superfície como em profundidade são considerados equivalentes, porém, nas situações em que há necessidade de se realizar um grande número de análises diárias, apresentam limitações óbvias: nesses casos, os microbiologistas freqüentemente sacrificam a precisão dos resultados, omitindo a duplicata ou triplicata (Silva et al., 1996). Franco (1999a) acrescenta que, apesar da aparente simplicidade da contagem em placas de Petri, essa técnica é bastante trabalhosa e sujeita a erro, quando muitas diluições precisam ser efetuadas, e que a leitura dos resultados pode ser difícil, cansativa e imprecisa. Outra desvantagem do método convencional é que a alta temperatura do ágar fundido $\left(48^{\circ} \mathrm{C}\right)$ pode causar destruição ou injúria de algumas bactérias sensíveis ao calor (Chain \& Fung, 1991).

Quanto à técnica do número mais provável (NMP), também chamada de técnica dos tubos múltiplos, Jay (1998) reporta que foi introduzida por McCrady em 1915 e que não é um método de análise preciso, por ter natureza estatística, e os resultados do NMP são geralmente maiores do que a contagem de colônias em placas. Tortora et al (2000) explicam que o NMP é baseado no seguinte princípio: quanto maior o número de 
bactérias em uma amostra, maior será o número de diluições necessárias para eliminar totalmente o crescimento em tubos contendo o meio de cultivo, o que provoca mudanças nesse microambiente (turbidez, produção de gás...). Pelo número de tubos positivos em cada uma das diluições empregadas, determina-se o NMP por grama ou mililitro de produto, com base na tabela estatística de Hoskins para três ou cinco tubos.

O método do NMP fornece somente uma estimativa de $95 \%$ de probabilidade de que a amostra analisada contenha o número de bactérias determinado pela tabela estatística de NMP (Tortora, 2000). Outros inconvenientes do uso dos tubos múltiplos são a necessidade de grande quantidade de vidraria, a falta de oportunidade de observação da morfologia das colônias e a falta de precisão. Mesmo assim, esse método de análise tem se tornado popular e suas vantagens são citadas por Jay (1998): ser um método relativamente simples; poder determinar grupos específicos de microrganismos através do uso de meios seletivos e diferenciais apropriados; ser o método de eleição para determinação do número de coliformes fecais. Franco (1999b) acrescenta que a técnica dos tubos múltiplos ainda é bastante utilizada pelos laboratórios para enumeração de coliformes totais, fecais e E. coli em laticínios e, além de trabalhosa, uma análise completa por essa técnica é muito demorada.

\subsubsection{Métodos rápidos de análise microbiológica}

O termo método rápido refere-se a métodos que dão resultados seguros em menor tempo, quando comparados aos métodos convencionais. Porém, métodos que facilitem o preparo de amostras no laboratório e, dessa forma, possibilitem aumentar o número total de amostras analisadas/tempo, ainda que os resultados sejam obtidos em tempo similar aos convencionais, também são descritos como rápidos (Vasavada et al., 1993). Algumas técnicas atingem os dois objetivos simultaneamente.

Nas últimas duas décadas, vários métodos e instrumentos foram desenvolvidos como alternativas aos convencionais. Entre as novas tecnologias, destacam-se o plaqueamento em espiral, filtração em membrana com grade hidrofóbica (HGMF), microscopia de fluorescência, citometria de fluxo, técnicas de impedância e condutância, 
além de "kits" para caracterização de microrganismos. São listados ainda o método da bioluminescência, métodos imunoenzimáticos e com ácidos nucléicos para a detecção de patógenos específicos e toxinas (FUNG, 1999) ${ }^{1}$ citado por Beloti 2000.

Dentre os sistemas alternativos desenvolvidos e disponibilizados no comércio para enumeração de microrganismos, merecem destaque os chamados "prontos para uso", nos quais se enquadram as placas Petrifilm ${ }^{\circledR}(3 \mathrm{M})$ e Simplate $^{\circledR}$ (BIOCONTROL) (Franco, 1999a).

\subsubsection{Placas Petrifilm ${ }^{\circledR}$ para contagem de aeróbios mesófilos (Petrifilm ${ }^{\circledR}$ AC)}

Uma revolução nos métodos de análise microbiológica de alimentos foi provocada com o lançamento das placas de Petrifilm ${ }^{\bullet}$ (3M Co, St. Paul, Mn, EUA), inicialmente desenvolvidas para a contagem de bactérias aeróbias totais e, posteriormente, diversificadas para outros grupos de microrganismos (Franco, 1994). O sistema Petrifílm ${ }^{\circledR}$ é baseado na multiplicação de microrganismos em meios de cultivo apropriados.

Para a contagem de aeróbios, o meio de cultivo do Petrifilm ${ }^{\circledR} \mathrm{AC}$ contém os nutrientes do Ágar Padrão para Contagem (PCA). O Petrifilm ${ }^{\circledR}$ AC é apresentado na forma de cartões de papel (chamados de placas Petrifilm), revestidos pelo meio de cultivo desidratado, contendo o corante indicador 2,3,5-cloreto de trifeniltetrazólio (TTC) e agentes geleificantes solúveis em água. As placas são cobertas por uma película transparente, que tem voltada para a placa um gel hidrossolúvel e o corante indicador. A película protetora é marcada por quadros de $1 \mathrm{~cm}^{2}$ (Figura 1).

\footnotetext{
${ }^{1}$ FUNG, D.Y.C. Predictions on the future of rapid methods in microbiology. Food Testing \& Analysis, v.5, n.3, p.18-21, 1999.
} 


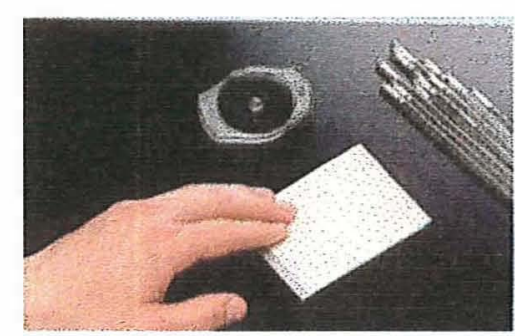

(a)

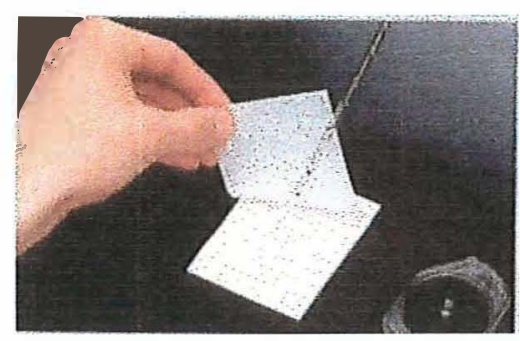

(b)

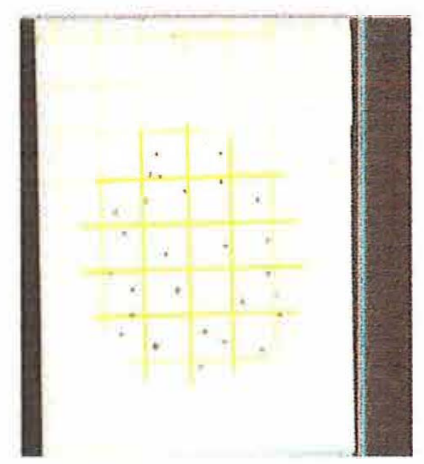

(c)

Figura 1 - (a) Placa Petrifilm ${ }^{\circledR}$ AC

(b) Inoculação da amostra na placa

(c) Placa Petrifilm ${ }^{\circledR} \mathrm{AC}$ após o período de incubação

O filme inferior é inoculado com $1 \mathrm{ml}$ das diluições da amostra e é coberto com o filme superior. A água do inóculo reconstitui o meio de cultivo desidratado e solubiliza os agentes geleificantes presentes na placa e na película plástica. Após cerca de 1 minuto o meio de cultivo adquire consistência e as placas podem ser incubadas, em posição horizontal, com a superfície transparente voltada para cima. O tempo/temperatura de incubação seguem o sistema tradicional de análise, porém a vantagem sobre o método 
tradicional é que dispensa preparo de meios de cultivo, podendo ser utilizado em trabalhos de campo, pela facilidade de uso (Silva et al., 1997) (Figura 1).

No Petrifilm ${ }^{\circledR} \mathrm{AC}$, as colônias apresentam-se vermelhas devido à redução do TTC presente no meio (Hajdenwurcel, 1998). O TTC, que é incolor na forma oxidada, tornando-se vermelho quando reduzido. Em organismos vivos essa redução ocorre pela ação de enzimas, originando o formazano, que se acumula em grânulos vermelhos intracelulares, apontados como sítios de redução (Jones \& Prasad, 1969) ${ }^{2}$ citados por Beloti (2000).

Como na contagem de colônias pelo método convencional de plaqueamento em profundidade, Ginn et al. (1984) explicam que, também para o Petrifilm ${ }^{\circledR} \mathrm{AC}$, os meios que contiverem de 30 a 300 UFC são considerados apropriados para a contagem. Entretanto, informações fornecidas pelo fabricante das placas Petrifilm ${ }^{\circledR} \mathrm{AC}$ recomendam que o número máximo de UFC não seja superior a 250. Quando a contagem for superior a esse valor, recomenda-se que seja feita uma estimativa, enumerando-se as colônias em um ou mais quadrados representativos, determinando-se o número médio por quadrado e multiplicando-se esse número por 20, para a determinação da contagem total/placa. A contagem de colônias pode ser feita a olho nu ou utilizando-se um contador tipo Quebec. No Petrifilm ${ }^{\circledR}$ é possível recuperar as colônias, caso haja necessidade de submetê-las a testes posteriores (Franco, 1994).

Beloti et al. (1999a) chamam atenção para o uso de métodos rápidos que se utilizam do TTC. Esses autores, analisando leite pasteurizado, encontraram diferença na contagem padrão em placas comparada ao Petrifilm ${ }^{\circledR} \mathrm{AC}$, sendo neste, na maioria das vezes, menores as contagens. Os autores atribuem ao fato de que, no Brasil, o leite pasteurizado apresenta grande quantidade de flora Gram positiva não redutora, ou fracamente redutora do indicador TTC. Beloti et al (1999b) afirmam que esse fenômeno parece ser restrito ao leite pasteurizado produzido em certas regiões do país e é decorrente de micrococos, corineformes, e alguns bacilos Gram positivos remanecentes

\footnotetext{
${ }^{2}$ JONES, P.H.; PRASAD, D. The use of tetrazolium salts as a measure of sludge activity. J. Water Poll. Control Fed, Washington, v.41, n.11, p.R411-R449, 1969.
} 
no leite pasteurizado. Beloti et al (1999c) encontraram uma diminuição na correlação e um aumento na variância, de acordo com a qualidade do leite, ao contrário dos trabalhos publicados em países com melhores condições de higiene, indicando que fatores intrínsecos à produção e/ou beneficiamento do leite pasteurizado devem estar ligados à diferença observada entre os métodos avaliados. Várias pesquisas realizadas no Brasil utilizando o Petrifilm ${ }^{\circledR} \mathrm{AC}$, com leite pasteurizado, mostraram contagens totais de aeróbios mesófillos inferiores no Petrifilm, comparado ao método convencional (Beloti, 2000; Beloti et al., 1999b; Beloti et al., 1999c; Prata \& Figueira, 1998).

Ginn et al. (1984) afirmam que, no Petrifilm ${ }^{\circledR} \mathrm{AC}$, as colônias de bactérias aparecem em várias tonalidades de vermelho devido à diferente habilidade de redução do TTC e explicam que, ocasionalmente, uma ou outra colônia pode aparecer branca ou amarelada, mas, independente da cor, todas as colônias são contáveis, como no método convencional.

Fatores físico-químicos também interferem na redução do TTC, como $\mathrm{pH}$, temperatura e concentração do indicador, esse último podendo funcionar como inibidor de crescimento de certos microrganismos. Há demonstrações de que concentrações mínimas de TTC permitem o crescimento bacteriano, sem provocar qualquer efeito inibitório. No entanto, essa concentração mínima é específica para cada espécie bacteriana, e tem uma grande variação. O desenvolvimento da coloração depende do número de microrganismos presente e também da concentração do TTC adicionado ao meio de cultivo. Então, o corante deve estar presente em concentração menor do que a inibitória mínima, mas suficiente para desenvolver uma coloração intensa o bastante para uma visualização macroscópica das colônias (TENGERDY et al., 1967) ${ }^{3}$ citados por Beloti (2000), que reafirma a importância de se conhecer a microbiota do leite brasileiro e qual o seu comportamento na presença do TTC.

Atualmente são comercializadas placas Petrifilm $^{\circledR}$ para contagem de microrganismos aeróbios, coliformes, Escherichia coli, Enterobacteriaceae, fungos e Staphylococcus aureus. Foram desenvolvidas também placas para a contagem de

\footnotetext{
${ }^{3}$ TERGERDY, R.P.; NAGY, K.G.; MARTIN, B. Quantitative measurement of bacterial growth by the reduction of tetrazolium salts. Appl. Microb., v.15, n.3, p.954-55, 1967.
} 
coliformes em $5 \mathrm{~mL}$, chamadas de placas Petrifilm ${ }^{\circledR}$ de Alta Sensibilidade para a Contagem de Coliformes (HSCC).

As mesmas placas Petrifilm ${ }^{\circledR}$ AC podem ser usadas para a contagem de bactérias láticas, variando-se apenas o diluente. Nesse caso, deve ser empregado o caldo MRS, que é seletivo para bactérias produtoras de ácido lático. A incubação das placas deve ser feita em anaerobiose por $48 \pm 2 \mathrm{~h}$ a $30-35^{\circ} \mathrm{C}$ (Franco, 1994). As colônias de bactérias láticas, nesse meio, apresentam coloração vermelha ou marrom avermelhada, podendo apresentar bolhas de gás (heterofermentativas) ou não (homofermentativas). McGregor et al. (1995), reportam que placas Petrifilm ${ }^{\circledR} \mathrm{AC}$ incubadas em atmosfera com oxigênio reduzido são uma alternativa viável para recuperação de bactérias láticas.

\subsubsection{Placas Petrifilm ${ }^{\circledR}$ para contagem de coliformes totais com diferenciação de Escherichia coli (Petrifilm ${ }^{\circledR}$ EC)}

Nas placas Petrifilm ${ }^{\circledR}$ EC, o princípio é idêntico ao das placas para contagem de aeróbios: também contém um agente geleificante solúvel em água fria, porém, o meio de cultivo utilizado contém os nutrientes do ágar vermelho violeta bile (VRBA) com um indicador de atividade glucuronidásica para E. coli, o 5-bromo-4-cloro-3-indolil- $\beta$-Dglucuronídeo (BCIG), e um indicador tetrazólico para facilitar a enumeração das colônias.

No Petrifilm ${ }^{\circledR} \mathrm{EC}$, as colônias de coliformes apresentam-se vermelhas, pela redução do indicador, e associadas a bolhas de gás, devido à fermentação da lactose. De acordo com o fabricante, colônias sem gás não devem ser consideradas coliformes. A $E$. coli produz a enzima glucuronidase, que reage com o corante indicador glucuronidásico, formando um precipitado azul em volta da colônia, além de formação de gás, o que permite sua identificação visual (Hajdenwurcel, 1998).

A apresentação da placa e o modo de inoculação da amostra são similares ao do Petrifilm ${ }^{\circledR}$ para aeróbios mesófilos (Figura 2). 


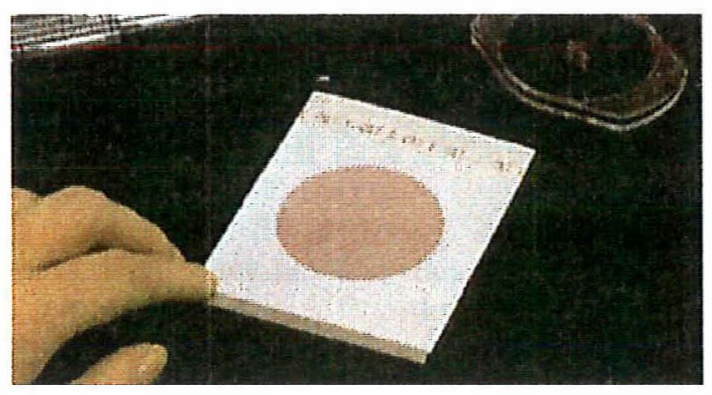

Figura 2 - Placa Petrifilm ${ }^{\circledR}$ EC.

Segundo a descrição do Método AOAC (991.14) no manual do Petrifilm ${ }^{\circledR}$ EC, a contagem de coliformes totais corresponde ao total de colônias azuis e vermelhas associadas com gás após 24 h de incubação a $35^{\circ} \mathrm{C}$. Após esse período, as placas devem ser reincubadas por mais $24 \mathrm{~h}$, para detectar um possível crescimento de novas colônias de E. coli. O fabricante recomenda enumerar todas as colônias azuis a vermelhoazuladas associadas com gás, independente de seu tamanho, como E. coli confirmado. Colônias azuis, porém sem formação de gás, não devem ser enumeradas como E. coli. Em placas que contenham mais de 150 colônias, as contagens podem ser estimadas, contando-se o número de colônias em um ou mais quadrados representativos e determinando-se o número médio por quadrado, o resultado é então multiplicado por 20.

Nas placas Petrifilm ${ }^{\circledR}$ EC as cepas de E.coli 0157:H7, por serem glucuronidase negativas, não formam o precipitado azul em torno da colônia, portanto, aparecem com características de coliforme não E. coli. 


\subsubsection{SimPlate para contagem total de aeróbios mesófilos (SimPlate ${ }^{\circledR}$ TPC)}

Recentemente o sistema SimPlate ${ }^{\circledR}$ TPC foi desenvolvido para determinar o número mais provável (NMP) de organismos aeróbios mesófilos em alimentos (Townsend ${ }^{4}$ et al., 1996) citados por Beauchat et al. (1998).

O Simplate ${ }^{\circledR}$ utiliza "kits" compostos por um frasco contendo o substrato desidratado específico e placas descartáveis de material plástico, com 84 ou 198 cavidades. As placas são apresentadas de maneira que permitem a determinação do número mais provável (NMP) a partir do número de cavidades positivas convertido em contagem total através de uma tabela de NMP apropriada (ANEXO A). De acordo com as instruções de uso, no Simplate ${ }^{\circledR} \mathrm{TPC}$, as cavidades que apresentarem fluorescência sob luz UV a $365 \mathrm{~nm}$, são consideradas positivas para organismos aeróbios mesófilos (Figura 3).

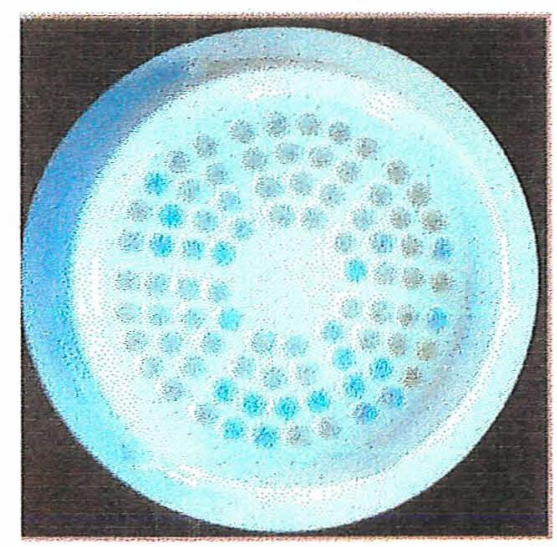

Figura 3 - Placa SimPlate ${ }^{\circledR}$ TPC, vista sob luz ultravioleta a 365 nm.

O princípio do método SimPlate ${ }^{\circledR}$ é baseado na tecnologia de substrato enzímico múltiplo que correlaciona atividade enzímica com a presença de bactérias viáveis no

\footnotetext{
${ }^{4}$ TOWNSEND, D.E.; CROTEAU, 22A.J.; NAQUI, A. A new medium designed to detect and quantify the total viable bacterial count of food after only 24 hours of incubation. 24p. 382. Abstr. $96^{\text {th }}$ Gen.Meet. Am. Soc. For Microbiol., New Orleans, LA, 1996.
} 
alimento (Hajdenwurcel, 1998). No caso do SimPlate ${ }^{\circledR}$ TPC, o substrato de enzimas múltiplas presente no meio é alvo de diferentes enzimas bacterianas. Nem todas as bactérias possuem cada uma das enzimas, porém, a presença de uma delas é suficiente para que ocorra a deteç̧ão das bactérias (Townsend \& Naqui, 1998). No SimPlate ${ }^{\circledast}$, é a atividade bioquímica, e não o crescimento de colônias que determina se há bactérias viáveis presentes no alimento. A deteç̧ão por esse processo bioquímico é a razão do curto período de incubação (Beuchat et al., 1998) de 24 h, o que representa uma economia de tempo, comparado ao plaqueamento convencional, que requer período de incubação de 48h (Townsend \& Naqui, 1998). Cutolo et al. (1998) destacam ainda a vantagem desse método eliminar a interferência de partículas de alimentos.

A composição dos meios utilizados para a quantificação de aeróbios mesófilos pelo método SimPlate ${ }^{\circledR}$ TPC não é divulgada pelo seu fabricante (Campregher, 2000). Beauchat et al. (1998) afirmam que o substrato enzímico do SimPlate ${ }^{\circledR}$ TPC não é indicado para alimentos como figado cru, farinha de trigo e nozes, pois esses alimentos contêm enzimas naturais que podem provocar reações falso-positivas no meio. Visando contornar esse problema, recentemente, foi desenvolvido um novo substrato para a contagem de aeróbios mesófilos em SimPlate ${ }^{\circledR}$. O novo substrato não usa reação enzímica e sim um corante indicador para detectar e quantificar bactérias em alimentos, através da redução do indicador. O novo meio já foi testado, inclusive com os alimentos que apresentam o problema de reações falso-positivas devido à presença das enzimas naturais, e foram encontrados resultados altamente correlacionados com o método convencional de contagem em placas. Além disso, não foi observada interferência das enzimas dos alimentos com potencial de interferência nos resultados (Smith \& Townsend, 1999).

Atualmente também estão disponíveis no mercado placas SimPlate ${ }^{\circledR}$ para detecção de Campylobacter em alimentos. 


\subsubsection{SimPlate para coliformes totais e $E$. coli (SimPlate ${ }^{\circledR}$ CEc)}

O sistema SimPlate ${ }^{\circledR} \mathrm{CEc}$ também é baseado na tecnologia de substrato definido. Este método correlaciona a presença de coliformes totais e $E$. coli com a presença de $\beta$ galactosidase e $\beta$-glucuronidase, respectivamente.

O composto vermelho clorofenol $\beta$-D-galactopiranosídeo (CPRG) presente no substrato do SimPlate ${ }^{\circledR} \mathrm{CEc}$, quando hidrolizado pela enzima $\beta$-galactosidase, produz o composto vermelho clorofenol (CPR) que possui coloração laranja a púrpura (Figura 4). O composto 4-metilumbeliferil- $\beta$-D-glucoronídeo (MUG), quando hidrolizado pela enzima $\beta$-glucuronidase, produz a 4-metilumbeliferona, que apresenta cor azul fluorescente, quando exposta à UV a $365 \mathrm{~nm}$. O número de cavidades positivas é convertido em contagem total de coliformes ou E.coli através da tabela de NMP apropriada (Hajdenwurcel, 1998) (ANEXO A).

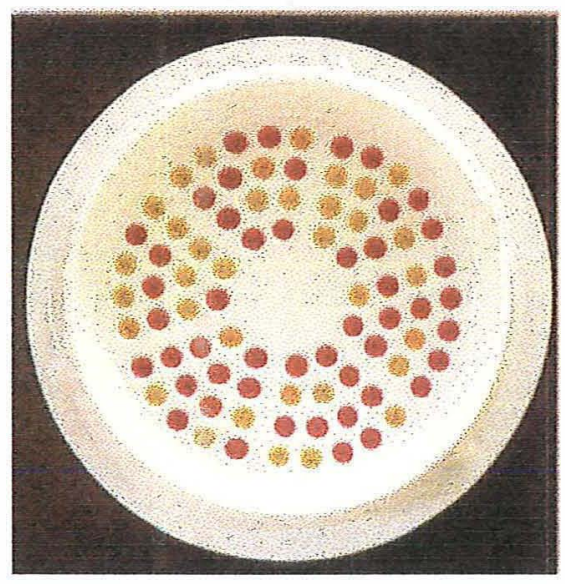

Figura 4 - Placa SimPlate $\mathrm{CEc}^{\circledR}$.

A importância do 4-metilumbeliferil- $\beta$-D-glucoronídeo é que a $E$. coli é a principal produtora de $\beta$-glucuronidase, portanto esse substrato tem sido largamente empregado como agente diferencial em meios para detecção dessa bactéria. Vale lembrar que algumas cepas de Salmonella, Shigella e corinebacteria também são $\beta$ - 
glucuronidase positivas (Jay, 1998). O gênero Shigella é intimamente relacionado com a E. coli (Berger, 1994). Numa pesquisa conduzida por esse autor, o fato de ter sido encontrada uma alta porcentagem de Shigella produtora de $\beta$-glucuronidase, que resultou em resultados positivos em substratos que utilizaram o MUG, foi considerado benéfico para a saúde pública, devido à importância de Shigella como agente de disenteria.

Um aspecto importante dos métodos fluorogênicos é a ocorrência da fluorescência antes da produção de gás a partir da lactose (Jay, 1998). Esse autor menciona ainda a possibilidade de algumas cepas de E. coli serem anaerogênicas. Também lembra que algumas cepas de E.coli $\mathrm{O} 157$ são $\beta$-glucuronidase negativas, o que pode levar a resultados falso-negativos em substratos que utilizam o MUG.

\subsection{Aspectos relativos a critérios microbiológicos e aprovações por órgãos oficiais}

\subsubsection{Critérios microbiológicos}

Critérios microbiológicos podem ser obrigatórios ou de orientação. Alimentos que estiverem em desacordo com os critérios obrigatórios devem ser reprovados. A reprovação significa, entre outras possíveis: destruição do produto, reprocessamento, devolução do produto ao fabricante e suspensão da licença de comercialização. Já os critérios de orientação servem para alertar sobre possíveis problemas no processamento, armazenamento, distribuição e comercialização dos alimentos, sem necessidade de providências drásticas como as que determinam um critério obrigatório.

Padrão microbiológico é um critério obrigatório, pois faz parte de uma lei ou de uma regulamentação administrativa. O não atendimento ao padrão microbiológico vigente constitui violação da lei, e medidas legais por parte dos órgãos competentes são possíveis. Por outro lado, normas microbiológicas são de orientação e correspondem a um critério utilizado pela indústria alimentícia para monitoramento dos pontos críticos de controle de todo o processo produtivo. Essas normas são criadas pelas indústrias e podem ser mais ou menos rígidas do que os padrões microbiológicos (Franco, 1996b). 
Nesse sentido, Oliveira (2001) explica que conceitos de qualidade baseados em inspeção e defeitos apresentados no produto final vêm sendo substituídos por atitudes de controle de todo o processo, tanto da matéria-prima, do processamento, do meio ambiente e das pessoas envolvidas.

No Brasil, os padrões microbiológicos para alimentos são definidos pelos Ministérios da Saúde e da Agricultura. Alguns Estados da Federação, assim como alguns municípios, possuem legislação própria (Franco, 1996c). A resolução RDC nº12, da Agência Nacional de Vigilância Sanitária do Ministério da Saúde, de 2 de Janeiro de 2001, estabelece padrões microbiológicos sanitários para alimentos destinados ao consumo humano (ANVISA, 2001). No caso do leite cru, cabe ao Ministério da Agricultura estabelecer os padrões microbiológicos.

A legislação brasileira não permite o comércio de leite cru direto ao consumidor: “Nas localidades onde existir usina de beneficiamento de leite, não é permitida a venda de leite cru, não podendo a autoridade estadual ou municipal dar concessão para o comércio deste tipo de leite” (BRASIL, 1952). Essa é uma das razões de não existirem padrões microbiológicos para leite cru mais recentes do que aqueles estipulados em 1952 (Quadro 1). Mesmo a Portaria N 56, de 7 de Dezembro de 1999, do Ministério da Agricultura, que submete à consulta pública novos Regulamentos Técnicos, traz esses mesmos padrões microbiológicos para o leite cru (BRASIL, 2000). Nessa mesma portaria, foram incluídos os padrões microbiológicos para o leite cru refrigerado, a serem seguidos a partir de 01 de Julho de 2002, para as regiões Sul, Sudeste e Centrooeste e, a partir de 01 de Julho de 2004, para as regiões Norte e Nordeste.

Uma Nota Técnica ${ }^{5}$, publicada pelo Ministério da Agricultura, estabelece o prazo de 01 de Julho de 2005 para as regiões Sul, Sudeste e Centro-Oeste, e de 01 de Julho de 2007 para o Norte e Nordeste, para a vigência oficial dos índices de qualidade do leite cru refrigerado na propriedade rural. O referido documento propõe índices de qualidade para a contagem padrão em placas de no máximo $1,0 \times 10^{6} \mathrm{UFC} / \mathrm{mL}$, seguido

\footnotetext{
5 BRASIL. Ministério da Agricultura Pecuária e Abastecimento. Secretaria de Defesa Agropecuária. Departamento de Inspeção de Produtos de Origem Animal. Nota Técnica de maio de 2002. 2p.
} 
por 7,5 $\times 10^{5} \mathrm{UFC} / \mathrm{mL}$ e por $1,0 \times 10^{5} \mathrm{UFC} / \mathrm{mL}$, a serem implantados, gradativamente, em todas as regiões do país, em diferentes períodos (BRASIL, 2002).

\begin{tabular}{|c|c|}
\hline Tipo de leite & $\begin{array}{c}\text { Padrão microbiológico antes da pasteurização } \\
\text { Contagem de aeróbios mesófilos }\end{array}$ \\
\hline Tipo A & $1,0 \times 10^{4} \mathrm{UFC} / \mathrm{mL}$ \\
\hline Tipo B & $5,0 \times 10^{5} \mathrm{UFC} / \mathrm{mL}$ \\
\hline Tipo C e demais tipos & não especificado \\
\hline
\end{tabular}

Quadro 1 - Padrões microbiológicos para o leite cru.

Fonte: BRASIL (1952)

\subsubsection{Aprovações por órgãos oficiais}

Quanto a aprovações, tanto o Petrifilm ${ }^{\circledR}$ para contagem total de aeróbios mesófilos como para coliformes e $E$. coli são aprovados em ação final pela AOAC para serem utilizados em alimentos em geral. O método é também aprovado pela (APHA, 1992) para estar incluído no Standard Methods for the Examination of Dairy Products (SMEDP) como método microbiológico alternativo. Por ter aprovações legais de uso pelos mais importantes órgãos internacionais de validação de métodos, como o FDA, AOAC e Association Française de Normalisation (AFNOR), entre outros, o Petrifilm ${ }^{\circledR}$ está sendo rapidamente adotado pelas indústrias de leite e derivados no Brasil (Franco, 1998). O SimPlate ${ }^{\circledR}$ TPC recebeu certificado de aprovação da AOAC em 05 de março de 1997 - "Certificate of Performance Tested Status" (ANEXO B) (AOAC, 2002).

Em qualquer método de análise microbiológica, Ginn et al. (1984) destacam a exatidão e a reprodutibilidade como características importantes. Além destas, aprovação por órgãos oficiais, simplicidade de execução e custo devem ser considerados na escolha e implantação dos métodos rápidos (Silva et al., 1997). 


\subsection{Leite cru}

O leite pode ser considerado um alimento completo, contendo proteínas, gordura, lactose, vitaminas e minerais, juntamente com enzimas naturais e derivadas de microrganismos. Possui alto valor nutritivo, portanto é um excelente meio para crescimento microbiano (Varnam \& Sutherland, 1996).

Para o leite ser caracterizado como de boa qualidade, deve apresentar as seguintes características organolépticas, nutricionais, físico-químicas e microbiológicas: sabor agradável, alto valor nutritivo, ausência de agentes patogênicos e contaminantes, reduzida contagem de células somáticas e baixa carga microbiana. Dentre as características citadas, destaca-se a qualidade microbiológica do leite, que pode ser um bom indicativo da saúde da glândula mamária do rebanho e das condições gerais de manejo e higiene da produção (Fonseca et al., 1999). Do ponto de vista quantitativo, considera-se que leites com baixas contagens de microrganismos são os de melhor qualidade (Champagne \& Goulet, 1991; Wallem, 1984).

A qualidade microbiológica do leite é um termo amplo e pode ser enfocada sob dois diferentes prismas: qualidade industrial e risco à saúde pública. No leite cru está relacionada com o grau de contaminação inicial e com o tempo e temperatura em que o leite é mantido da ordenha até a pasteurização (Oliveira, 1976; Richter et al., 1992). Geralmente, quanto maior o número de contaminantes e quanto mais próxima de $30^{\circ} \mathrm{C}$ for a temperatura, menor será o seu tempo de conservação do leite (Oliveira, 1976); nessas condições, os microrganismos mesófïlos podem crescer rapidamente (Varnam \& Sutherland, 1996).

A refrigeração diminui a velocidade de multiplicação da maioria dos microrganismos encontrados no leite, todavia, não os destrói e muito menos paralisa a ação de suas enzimas. Um controle adequado no retardamento da velocidade de crescimento dos contaminantes só é possível na faixa de 0 a $4^{\circ} \mathrm{C}$ (Oliveira, 1976).

Embora a pasteurização destrua grande parte da flora bacteriana, tem que se considerar que a porcentagem de bactérias que sobrevive ao tratamento térmico é tanto maior quanto maior for o conteúdo microbiano antes do processo (Riedel, 1992). 


\subsubsection{Microbiologia do leite cru}

O leite, quando proveniente de animais sadios e obtido em condições higiênicas, contém número baixo de microrganismos: $<5,0 \times 10^{3}$ germes $/ \mathrm{mL}$ e $<1$ coliforme $/ \mathrm{mL}$. No interior de úberes saudáveis, os tipos de bactérias predominantes são Micrococcus, Streptococcus e Corynebacterium (Jay, 1996), além dos lactobacilos saprófitas do úbere e ductos galactóforos.

Já o leite de vacas infectadas por mastite ou outras doenças pode conter grande número de bactérias, eventualmente patogênicas para o homem (Pelczar, 1981). Em casos de infecção mastítica, Staphylococcus aureus, Streptococcus agalactiae e E. coli têm sido apontadas como as espécies mais importantes (Oliveira \& Caruso, 1996), além de Pseudomonas, todas podendo ser excretadas em alto número no leite (Jay, 1996). Behmer (1984) destaca a importância da sanidade do animal, a higiene da ordenha e a conscientização do perigo que o leite cru representa como veículo de microrganismos patogênicos. Tradicionalmente, o leite cru pode transmitir doenças como tuberculose, brucelose, febre Q e uma série de gastroenterites. Alguns surtos de salmoneloses, colibaciloses, listerioses, campilobacterioses, mycobacterioses e iersinioses têm chamado a atenção de pesquisadores, o que levou à classificação destes como doenças emergentes. Importantes agentes emergentes são Listeria monocytogenes, Yersinia enterocolitica, Campylobacter jejuni, Escherichia coli enteropatogênica, E. coli 0157:H7, E. coli O27:H20 enterotoxigênica, Streptococcus zooepidermicus e Mycobacterium paratuberculosis (Fonseca et al., 1999). Estimativas em 1993 revelavam que somente $75,5 \%$ da população brasileira tinham a opção de adquir leite pasteurizado para o consumo doméstico e o restante da população $(24,5 \%)$ adquiriam leite cru (Vargas, 1995).

Do ponto de vista tecnológico, os contaminantes mais importantes são os que atingem o leite quando este entra em contato com o meio ambiente, sendo variáveis a grandeza e a diversidade da contaminação (Oliveira, 1976; Zall et al., 1983). Fontes externas de contaminação incluem os microrganismos da superficie do animal, alimento, 
ar, água, utensílios, equipamentos de ordenha e das pessoas envolvidas no processo de produção (Jay, 1996; Pelczar, 1981; Richter et al., 1992).

Normalmente, a microbiota contaminante do leite é composta por bactérias, enquanto as leveduras e bolores ocorrem mais raramente (Lima, 1988). Em leite cru, sob condições normais, o crescimento desses dois últimos grupos não é esperado (Jay, 1996), já que ocorre mais lentamente do que o de bactérias, em alimentos de baixa acidez e alta atividade de água, que é o caso do leite (Landgraf, 1996). Dentre os contaminantes, predominam as bactérias ácido láticas, coliformes, Micrococcus, Staphylococcus, Enterococcus, Bacillus, esporos de Clostridium e bastonetes Gram negativos (Jay, 1996). Em condições adequadas de manipulação e armazenamento, predomina a flora Gram-positiva (Jay, 1998).

Em leite não refrigerado, o crescimento de mesófilos predomina, e inclui espécies de Lactococcus, Lactobacillus, Enterococcus, Micrococcus, Bacillus, Clostridium e coliformes seguidos por Pseudomonas, Proteus e outros. Nessas condições, o crescimento de espécies que hidrolizam a lactose, como Lactococcus spp. geralmente predomina, resultando em produção de ácido suficiente para baixar o $\mathrm{pH}$ consideravelmente e prevenir ou diminuir o crescimento de outros organismos (Ray, 1996).

Os grupos de microrganismos mais freqüentes em leites com baixa contagem de mesófilos são: micrococos não termodúricos e estafilococos (30 a 99\%), estreptococos (0 a 50\%), corineformes $(<10 \%)$, bacilos esporulados $(<10 \%)$ e outros $(<10 \%)$. Quando as contagens de mesófilos são elevadas, a porcentagem de micrococos termodúricos em relação aos outros micrococáceos é mais alta. Micrococos e Microbacterium sp. são termodúricos oriundos principalmente do equipamento de ordenha. A multiplicação desses microrganismos em leite refrigerado é lenta e sua presença em grande quantidade significa que a carga contaminante inicial foi elevada (Bramley \& McKinnon, 1990).

Quando o leite cru é resfriado imediatamente após a ordenha e mantido sob temperatura de refrigeração, aumentos na carga microbiana são geralmente por psicrotróficos como Pseudomonas, Flavobacterium e Alcaligenes spp. bem como algumas bactérias coliformes (Jay, 1996). Os psicrotróficos predominam nas situações 
em que há deficiência de higiene na ordenha, problemas de limpeza e sanitização do equipamento, associados com tempo de armazenamento longo de leite resfriado. Esses microrganismos têm distribuição ampla na natureza, sendo a água, o solo e os vegetais os seus principais habitat (Fonseca et al., 1999). As bactérias psicrotróficas Gramnegativas são capazes de produzir proteases e lipases termoestáveis que podem causar defeitos como gosto amargo e sabores alterados no leite. As enzimas produzidas por esses organismos psicrotróficos são termoestáveis e podem causar "off-flavors" nos produtos, mesmo após o processamento (Bigalke, 1984a).

\subsubsection{Microrganismos indicadores}

O termo microrganismo indicador pode ser aplicado a qualquer grupo taxonômico, fisiológico ou ecológico de microrganismos, cuja presença ou ausência proporciona uma evidência indireta referente a uma característica particular do histórico da amostra (Forsythe, 2002). De acordo com Landgraf (1996) microrganismos indicadores são grupos ou espécies de microrganismos que podem ser usados para refletir a qualidade microbiológica dos alimentos, fornecendo informações a respeito das condições higiênico-sanitárias de produção, processamento e armazenamento de alimentos, além de indicar a possível presença de patógenos e deterioração potencial do produto. É necessário que esses microrganismos tenham crescimento e número negativamente correlacionados com a qualidade do produto, sejam de fácil detecção, enumeração em curto espaço de tempo, facilmente distinguidos de outros microrganismos e não tenham seu crescimento afetado por outros componentes da biota do alimento (Jay, 1998).

\subsubsection{Microrganismos aeróbios mesófilos}

O grupo mais usado para avaliação microbiológica do leite pertence aos aeróbios mesófilos (Teixeira et al., 2000). Mesmo que esse grupo não seja o indicador ideal para predizer a deterioração de produtos mantidos sob refrigeração, sua enumeração tem 
importância especial na microbiologia de alimentos. Em produtos frescos, a enumeração de mesófilos indica a eficácia dos procedimentos sanitários usados durante o processamento e manejo do produto (Jay, 1996). Além disso, os mesófilos indicam, no caso do leite, se este permaneceu em temperaturas de abuso (Bigalke, 1984b).

Entre os métodos para avaliação da carga microbiana do leite na plataforma da indústria, o mais empregado é o da contagem bacteriana total (CBT), que é o total de microrganismos aeróbios mesófilos do leite. A CBT depende basicamente da carga microbiana inicial, bem como da taxa de multiplicação microbiana. Raramente uma alta CBT é decorrente de problemas de mastite, salvo algumas exceções, como casos de alta incidência de mastite causada por Streptococcus agalactiae, ou surtos de S. uberis ou E. coli (Fonseca et al., 1999). A influência da mastite na CBT depende do microrganismo, do estágio da infecção e da porcentagem do rebanho infectado (Murphy \& Boor, 2000).

Pode-se dizer que os microrganismos mesófilos predominam em situações em que há falta de condições básicas de higiene de uma maneira geral, bem como falta de refrigeração do leite. Nessas condições, há produção de ácido lático por lactobacilos, estreptococos, lactococos e algumas enterobactérias, gerando, consequentemente, acidez do leite, que é um dos problemas mais freqüentemente detectados na plataforma de recepção da indústria (Fonseca et al., 1999).

A CBT não indica as fontes de contaminação bacteriana, ou seja, as possíveis falhas que levam à alta contagem de bactérias. Para ajudar a diagnosticar essas falhas, enumeração de organismos psicrotróficos, termodúricos, esporos, estreptococos e coliformes podem ser úteis. Porém, contagens desses microrganismos não são infalíveis e são inviáveis de serem praticadas rotineiramente, sendo, portanto, usadas principalmente com finalidade de investigação (Bramley \& McKinnon, 1990).

Para Bigalke (1984b), um teste ideal para determinar a qualidade microbiológica do leite cru deveria incluir os seguintes fatores: rapidez, economia, refletir o número total de organismos na amostra de leite, o número de organismos psicrotróficos, as condições de produção na fazenda e o tempo e temperatura de armazenamento do leite cru, mas reconhece que seria difícil para um único teste refletir todos esses parâmetros. Há um consenso de que a contagem de bactérias psicrotróficas é o método mais 
apropriado para indicar as condições de produção na fazenda, entretanto, a contagem bacteriana total de mesófilos dá resultados em relativo curto período de tempo, além de ser econômica .

Bramley \& McKinnon (1990) reportam que para a International Dairy Federation (IDF), altas contagens iniciais de mesófilos no leite cru, como $>1,0 \times 10^{5}$ UFC $\mathrm{mL}^{-1}$, sugerem falhas de higiene na produção, enquanto que contagens menores do que $2,0 \times 10^{4} \mathrm{UFC} \mathrm{mL}^{-1}$ indicam boas práticas higiênicas. Murphy \& Boor (2000) afirmam que contagens totais menores do que $1,0 \times 10^{4} / \mathrm{mL}$ de leite podem ser atingidas em muitas fazendas. Além disso, é preconizado que alimentos com altas contagens microbianas $\left(10^{5}-10^{6} \mathrm{UFC} / \mathrm{mL}\right.$ ou g), desde que não tenham sido obtidos pela ação microbiana, apresentam risco de estarem deteriorados ou se deteriorando, de ter suas características organolépticas e nutricionais pioradas, além de maior probabilidade de conter microrganismos patogênicos e/ou deterioradores. De acordo com a ICMSF (1978), quando a deterioração pode ser notada pelo odor, sabor, ou pela aparência, a maioria dos alimentos contém mais de $10^{6} \mathrm{UFC} / \mathrm{g}$.

\subsubsection{Grupo Coliforme}

O grupo coliforme inclui todas as bactérias aeróbias e anaeróbias facultativas, Gram-negativas, não formadoras de esporos, na forma de bastonetes, capazes de fermentar a lactose, com produção de ácido e gás a $32^{\circ}$ ou $35^{\circ} \mathrm{C}$ dentro de $48 \mathrm{~h}$ (Christen et al., 1992).

O grupo dos coliformes totais é constituído pelos gêneros Escherichia, Citrobacter, Enterobacter e Klebsiella e aproximadamente vinte espécies, originárias não somente do trato gastrintestinal humano e de outros animais de sangue quente, como também de origem não entérica. Já o grupo de coliformes fecais apresenta as mesmas características do grupo de coliformes totais, porém, é restrito às bactérias capazes de fermentar a lactose com produção de gás à temperatura de $44,5-45,5^{\circ} \mathrm{C}$ em $24 \mathrm{~h}$ (Siqueira, 1995). Apesar da finalidade de selecionar, no grupo de coliformes fecais, 
apenas os coliformes de origem gastrintestinal, algumas cepas dos gêneros Enterobacter e Klebsiella não tem origem entérica (Hajdenwurcel, 1998; Silva et al., 1997).

$\mathrm{O}$ indicador microbiológico de poluição fecal mais empregado é o grupo coliforme, sendo a $E$. coli considerada de origem unicamente fecal (Roitmam et al., 1989), portanto, é indicadora de poluição fecal direta ou indireta. Assim, a enumeração de $E$. coli é mais adequada do que a simples determinação da contaminação fecal como grupo (Hajdenwurcel, 1998; Silva et al., 1997). Nas fezes humanas e de outros animais, cerca de 95\% dos coliformes existentes são Escherichia coli (Silva et al., 2000). A E. coli evidencia riscos da presença de patógenos entéricos que podem ocorrer nas áreas de produção e beneficiamento do leite (Kornachi \& Marth, 1982). Além da constatação de contaminação fecal, a presença dessa bactéria pode ter um significado particularmente importante, uma vez que existem linhagens enteropatogênicas para o homem e animais (Kornacki \& Marth, 1982). Alimentos contaminados com E. coli enteropatogênicas são um fator importante na contribuição para a alta incidência de diarréias em países em desenvolvimento (Aleixo \& Aver, 1996).

No caso de leite cru, a incidência de coliformes e $E$. coli tem recebido atenção considerável, parte pela sua associação com contaminação de origem fecal e consequente evidência de risco da presença de patógenos entéricos, parte pela sua importância como agente deteriorador do leite (Bramley \& McKinnon, 1990). Os coliformes são responsáveis por alterações organolépticas no leite, sendo a acidificação, a mais comum (Thielmann, 1995).

Christen et al. (1992) explicam que os resultados de análise de coliformes em leite cru devem ser interpretados de maneira diferente do que para leite pasteurizado pois os coliformes, em pequena quantidade, podem contaminar o leite cru sob condições normais de produção e ordenha. A contagem de coliformes é um importate índice de qualidade de leite cru (Costello et al., 2001). A presença de coliformes em leite cru está associada com contaminação por esterco e bactérias ambientais. Embora esse grupo de microrganismos seja usado como indicador de contaminação fecal, alguns têm origem no ambiente. Coliformes podem se acumular rapidamente em locais úmidos, com resíduos de leite, como no equipamento de ordenha, que se tornam a principal fonte de 
contaminação do leite (Bramley \& McKinnon, 1990). Além do equipamento contaminado, os coliformes podem contaminar o leite devido à ordenha de vacas com tetos sujos (Shultz et al., 2002). Geralmente contagens acima de $50 \mathrm{UFC} / \mathrm{mL}$ indicam pouca higiente na ordenha (Murphy \& Boor, 2000). A enumeração de coliformes em leite cru, além de avaliar o grau de limpeza e sanitização dos equipamentos de ordenha é um indicativo das condições de resfriamento do leite (Segurança..., 2001).

Baixas contagens de coliformes em leite cru não indicam necessariamente limpeza e desinfecção eficazes dos equipamentos, porém, contagens excedendo a 100 $\mathrm{mL}^{-1}$, são consideradas evidência de higiene insatisfatória na produção. Outra causa de contagens elevadas de coliformes em leite cru podem ser as infecções mastíticas causadas por esses microrganismos (Bramley \& McKinnon, 1990). Já Shultz et al., (2002) esclarecem que vacas com mastite raramente contribuem para o conteúdo de coliformes do leite mas, ocasionalmente, podem ser a razão de elevada contagem desses microrganismos no leite cru. 


\section{MATERIAL E MÉTODOS}

\subsection{Material}

3.1.1 Água peptonada $0,1 \%\left(\mathrm{H}_{2} \mathrm{Op}\right)$ - Diagnolab (713495)

3.1.2 Ágar Padrão para Contagem (PCA) - Difco (0479)

3.1.3 Caldo verde brilhante lactose bile 2\% (CVBLB) - Difco (0007)

3.1.4 Ágar eosina azul de metileno, segundo Teague (Ágar EMB) (ABNT/MB$3463,1991)$

3.1.5 Caldo Triptona (ABNT/MB-3463,1991)

3.1.6 Caldo VM-VP (ABNT/MB-3463,1991)

3.1.7 Ágar citrato de Simmons (ABNT/MB-3463,1991)

3.1.8 Placas e substratos do "Simplate ${ }^{\circledR, " ~ p a r a ~ a e r o ́ b i o s ~ m e s o ́ f i l o s ~ e ~ p a r a ~ c o l i f o r m e s ~}$ totais e E. coli (BIOCONTROL)

3.1.9 Placas Petrifilm ${ }^{\circledR}$ para contagem total de aeróbios mesófilos (3M)

3.1.10 Placas Petrifilm ${ }^{\circledR}$ para contagem de coliformes totais e E. coli (3M)

3.1.11 Reativo de alfa- naftol 5\% (ABNT/MB-3463,1991)

3.1.12 Solução de KOH 40\% (ABNT/MB-3463,1991)

3.1.13 Reativo de Kovac's (ABNT/MB-3463,1991)

3.1.14 Reagente vermelho de metila (ABNT/MB-3463,1991)

3.1.15 Soluções para coloração de Gram (ABNT/MB-3463,1991)

3.1.16 Equipamentos e vidraria tradicionalmente utilizados em laboratório de microbiologia 


\subsection{Métodos}

\subsubsection{Coleta das amostras}

Foram realizadas coletas semanais durante o período de Setembro de 2000 a Abril de 2001. Foram coletadas 31 amostras de leite cru, tipo B, diretamente do tanque refrigerado tipo "expansão" em uma indústria do município de Piracicaba que recebe leite de produtores da região. As amostras foram coletadas em frascos esterilizados, acondicionadas em recipiente isotérmico e transportadas para o setor de laticínios do Departamento de Agroindústria, Alimentos e Nutrição da Escola Superior de Agricultura "Luiz de Queiroz" da Universidade de São Paulo, onde foram realizadas as análises.

\subsubsection{Análises microbiológicas}

\subsubsection{Preparo das amostras}

Procedimentos do Standard Methods for Examination of Dairy Products publicado pela APHA (1992) foram seguidos, para o preparo das amostras e obtenção das diluições adequadas a cada análise microbiológica. Foi retirada, de cada amostra, uma alíquota de $10 \mathrm{~mL}$. A partir dessa alíquota, foram feitas diluições seriadas* até $10^{-8}$, sempre transferindo-se $10 \mathrm{~mL}$ para $90 \mathrm{~mL}$ de água peptonada $0,1 \%$ esterilizada (Figura $5)$. 


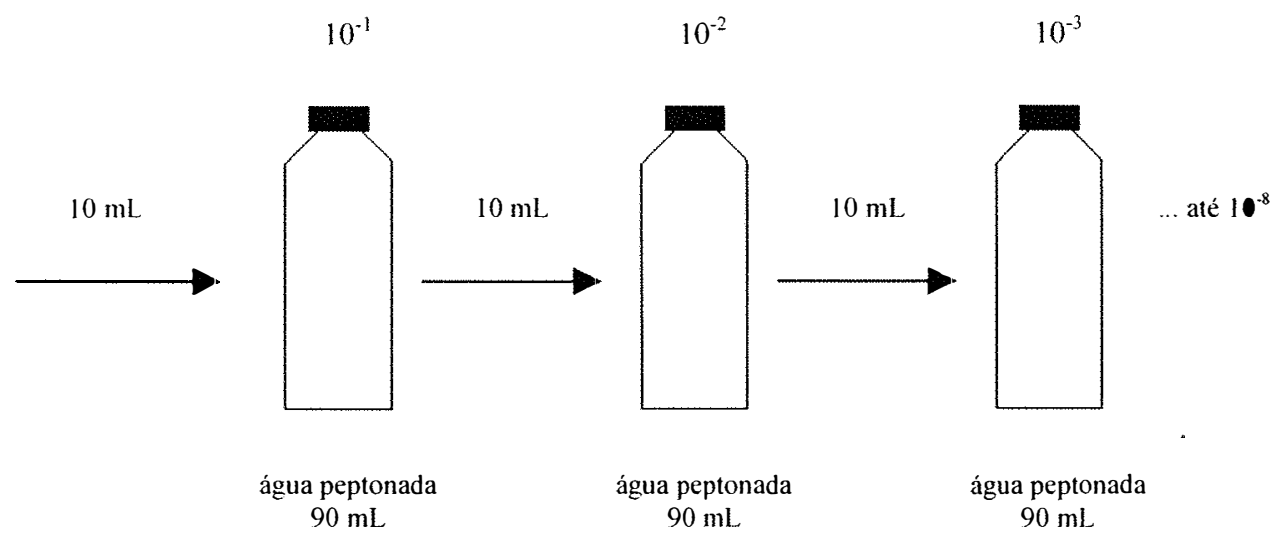

Figura 5 - Esquema para diluição das amostras.

*As diluições empregadas nas análises foram selecionadas de acordo com a estimativa de contaminação das amostras.

\subsubsection{Contagem total de microrganismos aeróbios mesófilos pelo método convencional}

Para esta avaliação, foram utilizados os procedimentos da APHA (1992). Foram plaqueados em profundidade, $1 \mathrm{~mL}$ de cada diluição $\left(10^{-3}\right.$ até $\left.10^{-6}\right)$, em duplicata, utilizando-se o meio de cultivo PCA. Após o plaqueamento, as placas permaneceram em repouso até a solidificação do meio e foram incubadas por $48 \mathrm{~h} / 32 \pm 1{ }^{\circ} \mathrm{C}$ (Figura 6). 


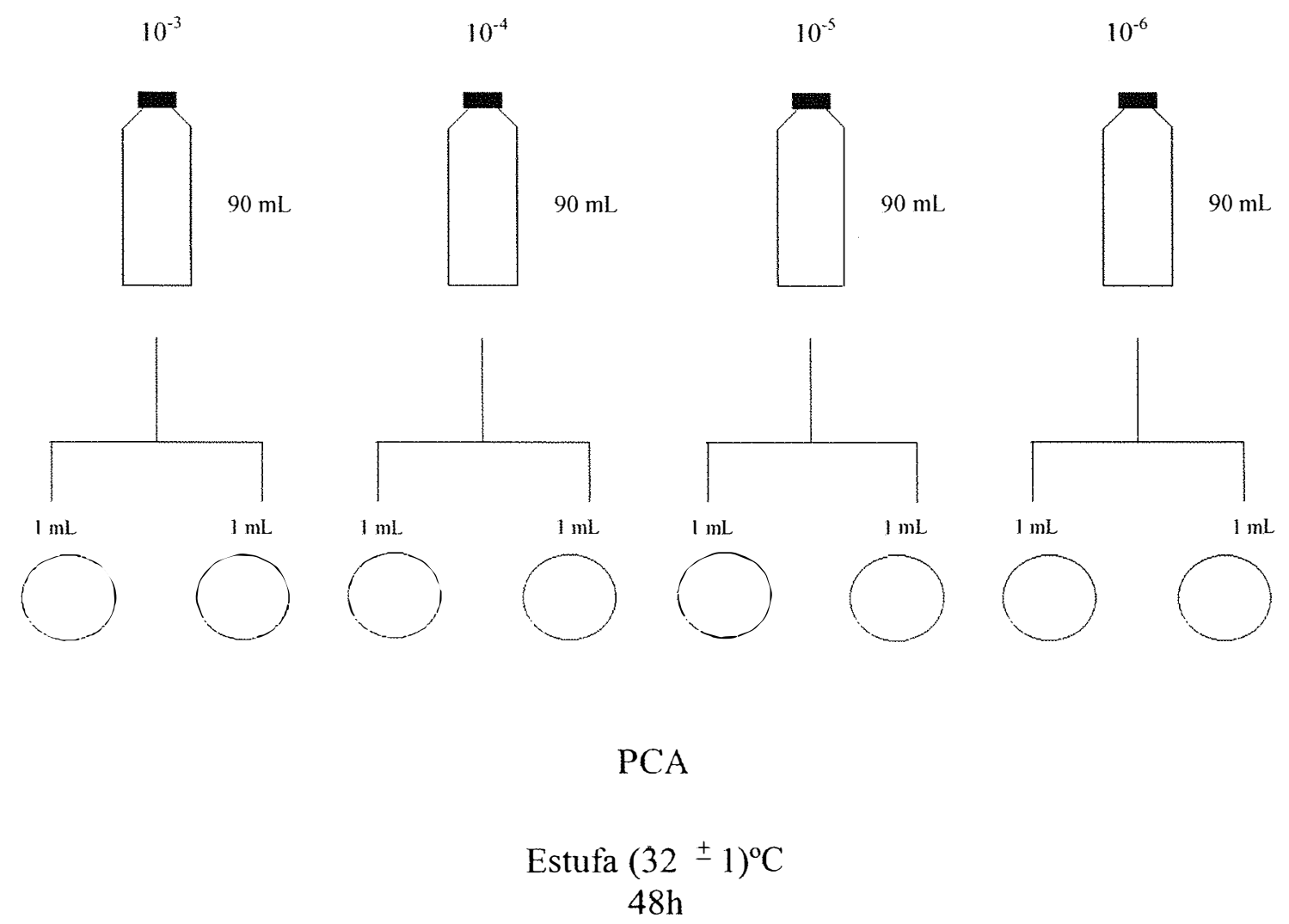

Figura 6 - Esquema da análise de aeróbios mesófilos pelo método convencional.

Placas com contagens entre 30 e 300 UFC foram selecionadas e fez-se a contagem das colônias, em contador de colônias tipo Quebec. O número total de UFC/mL foi obtido multiplicando-se a média aritmética das duplicatas pelo fator de diluição correspondente.

\subsubsection{Contagem total de microrganismos aeróbios mesófilos em Simplate ${ }^{\circledR}$}

Primeiramente, fez-se a hidratação do meio para cultivo de microrganismos mesófilos, adicionando-se o meio liofilizado a $100 \mathrm{~mL}$ de água destilada esterilizada e feita a dissolução por homogeneização manual.

Para cada placa, foram pipetados $1 \mathrm{~mL}$ das diluições $10^{-3}, 10^{-4}$ e $10^{-5}$ colocados no centro desta. Adicionaram-se, em seguida, $9 \mathrm{~mL}$ do substrato previamente hidratado, obtendo-se, assim, um volume de $10 \mathrm{~mL}$, necessário para estabelecer a correlação entre 
o número de cavidades positivas e a tabela de determinação do NMP. As placas foram agitadas em movimentos circulares até que todas as cavidades estivessem preenchidas pela mistura formada. $\mathrm{O}$ excesso foi vertido e descartado. As placas foram invertidas e incubadas a $32 \pm 1{ }^{\circ} \mathrm{C}$, por um período de $24 \mathrm{~h}$ (Figura 7).
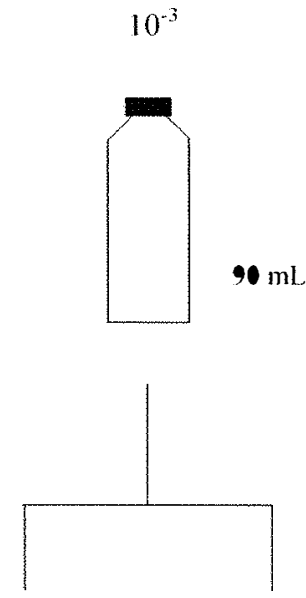

$1 \mathrm{ml}$
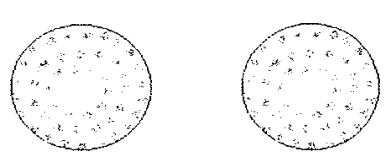

$10^{-4}$

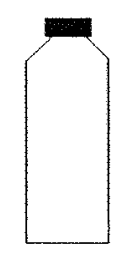

$90 \mathrm{~mL}$

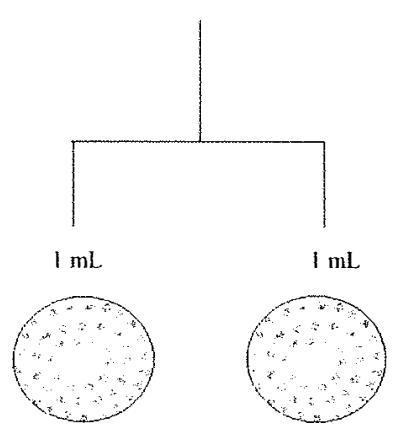

SimPlate ${ }^{\circledR}$ TPC.

Estufa $(32 \pm 1)^{\circ} \mathrm{C}$

$24 \mathrm{~h}$
$10^{-5}$
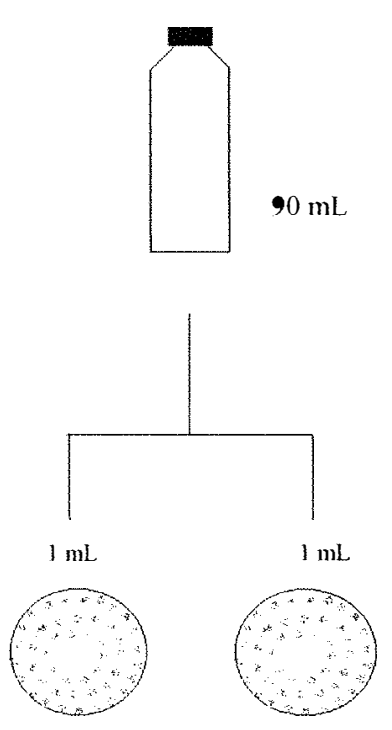

Figura 7 - Representação do procedimento analítico em SimPlate ${ }^{\circledR}$ TPC.

Após o período de incubação, foi feita a leitura das placas, em câmara de luz ultravioleta, $365 \mathrm{~nm}$ de comprimento de onda. De acordo com a recomendação do fabricante, as cavidades fluorescentes foram consideradas positivas e o NMP de organismos aeróbios mesófílos foi determinado através da tabela apropriada (ANEXO A). O número obtido na tabela multiplicado pelo fator de diluição representa o NMP de 
microrganismos $/ \mathrm{mL}$ na amostra. Os resultados foram obtidos pela média aritmética do NMP da duplicata.

\subsubsection{Contagem total de microrganismos aeróbios mesófilos em Petrifilm ${ }^{\circledR}$}

As placas Petrifilm ${ }^{\circledR}$ foram inoculadas com $1 \mathrm{~mL}$ das diluições selecionadas. Com o difusor plástico, a amostra foi distribuída uniformemente na placa. Após a solidificação, as placas foram incubadas, com a superfície transparente voltada para cima (Figura 8).

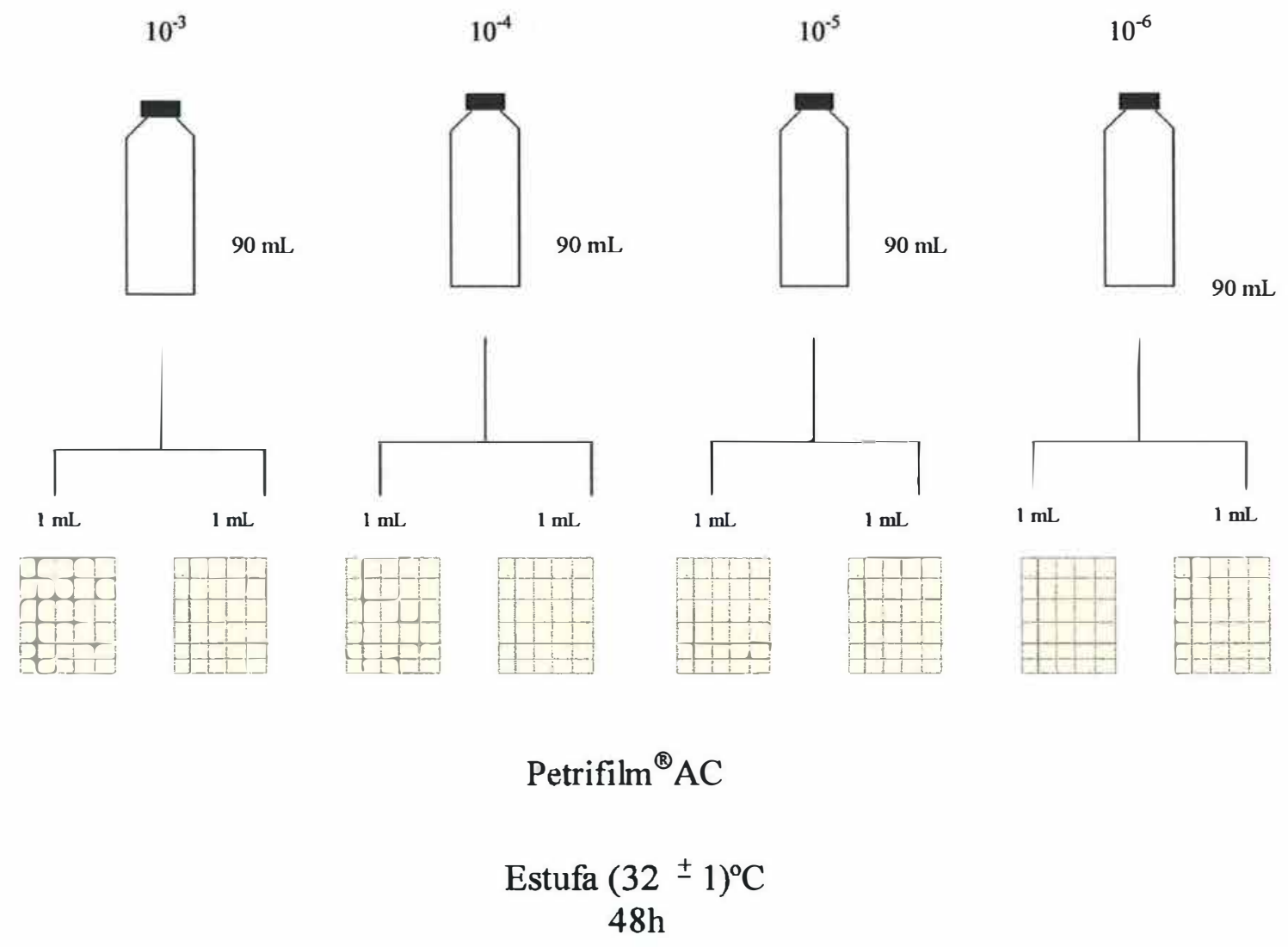

Figura 8 - Esquema do procedimento analítico em Petrifilm ${ }^{\circledR} \mathrm{AC}$ para a contagem total de microrganismos aeróbios mesófilos. 
A incubação das placas foi a $32 \pm 2^{\circ} \mathrm{C}$ por $48 \mathrm{~h}$. A contagem das colônias foi feita em contador de colônias tipo Quebec. Os resultados representam a média aritmética das UFC da duplicata.

\subsubsection{Enumeração de coliformes totais pela técnica dos tubos múltiplos (NMP)}

Para a determinação de coliformes totais e $E$. coli foi seguida a técnica prescrita pela ABNT, de novembro de 1991 (MB 3463). Essa técnica consta de duas fases distintas: a fase do teste presuntivo, na qual se busca detectar a presença de microrganismos fermentadores da lactose, sendo possível também recuperar células injuriadas e a fase do teste confirmativo, através do qual se determina a população real de coliformes totais e fecais.

$\mathrm{Na}$ análise de produtos lácteos, segundo a norma da ABNT, a prova presuntiva não é efetuada, sendo as inoculações realizadas diretamente em séries de três tubos contendo caldo verde brilhante lactose bile (CVBLB). Esse meio de cultivo, devido à presença de verde brilhante e sais biliares, é bastante seletivo. O meio inibe o crescimento de microrganismos Gram positivos e oferece condições de desenvolvimento para microrganismos mais adaptados às condições gastrintestinais, característica do grupo coliforme. A lactose presente no meio é utilizada pelos coliformes, e a presença desse grupo é evidenciada pela produção de gás.

Para a análise de coliformes totais foram utilizadas séries de 3 tubos, os quais continham um tubo de Durham e o meio de cultivo CVBLB. A primeira série constou de tubos contendo $10 \mathrm{~mL}$ de CVBLB em dupla concentração, uma vez que, nessa série, foram adicionados $10 \mathrm{~mL}$ do inóculo da diluição $10^{-1}$. As séries subseqüentes continham CVBLB em concentração normal, sendo que, em cada tubo da segunda série, foi adicionado $1 \mathrm{~mL}$ da diluição $10^{-1}$, em cada tubo da terceira série, $1 \mathrm{~mL}$ da diluição $10^{-2} \mathrm{e}$ assim, sucessivamente, até a diluição $10^{-8}$, faixa de diluição escolhida face aos resultados dos ensaios preliminares.

Após a inoculação, os tubos de CVBLB foram incubados em estufa termostatizada à temperatura de $32 \pm 1{ }^{\circ} \mathrm{C}$ durante $24-48 \mathrm{~h}$, sendo verificada, após esse 
período, a formação ou não de gás nos tubos de Durham. A presença de gás em CVBLB incubado a $32 \pm^{ \pm}{ }^{\circ} \mathrm{C}$ confirma a presença de bactérias do grupo coliforme, podendo ser de origem fecal ou não, denominadas coliformes totais.

De acordo com as normas da ABNT, a partir dos tubos positivos para coliformes totais, semeou-se, com alça de platina, tubos do mesmo meio (CVBLB 2\%) e tubos com caldo triptona. Estes foram mantidos sob imersão em água a $(44 \pm 1,0)^{\circ} \mathrm{C}$ por 24h. Após esse período, os tubos com CVBLB 2\% que apresentaram turvação do meio e produção de gás foram considerados positivos para coliformes fecais. Pela Tabela do NMP (ANEXO C), foi calculado o número mais provável de coliformes totais e fecais por mL de amostra.

Os tubos com caldo triptonado foram submetidos à prova de pesquisa de produção de Indol. Em cada tubo, foram adicionados 0,2 a $0,3 \mathrm{~mL}$ do reativo de Kovacs. O desenvolvimento de um anel vermelho-escuro na superfície do líquido foi considerado positivo para o teste do Indol.

\subsection{Identificação e cálculo do NMP de Escherichia coli}

A partir dos tubos positivos para coliformes fecais, foram semeadas, por estrias, placas com ágar Eosina Azul de Metileno (EMB). As placas foram incubadas a $35^{\circ} \mathrm{C}$ por 24h. Após a incubação, as colônias características de E. coli (nucleadas, com brilho metálico e não mucóides) foram semeadas em PCA para o isolamento das mesmas. A partir das colônias isoladas em PCA, foi feita coloração de Gram e provas bioquímicas para confirmação de E. coli: Teste de Voges Proskauer (VP), Teste de Vermelho de Metila (VM) e Teste de Utilização de Citrato.

\section{- Teste de Voges Proskauer (VP)}

Foram inoculados tubos com $5 \mathrm{~mL}$ de caldo VM-VP e incubados a $35^{\circ} \mathrm{C}$ por 48h. Após o período de incubação, foram transferidos, assepticamente, $2,5 \mathrm{~mL}$ do conteúdo do tubo para outro tubo vazio esterilizado. A seguir, foram adicionados $0,6 \mathrm{~mL}$ 
de solução de alfa-naftol e $0,2 \mathrm{~mL}$ de solução de hidróxido de potássio a $40 \%$. Tubos nos quais houve desenvolvimento de coloração vermelha foram considerados positivos para o Teste de VP. O restante do caldo VM-VP foi reincubado para posterior realização do teste de vermelho de metila.

\section{- Teste de vermelho de metila}

Após a reincubação do caldo VM-VP por $48 \mathrm{~h}$ adicionais a $35{ }^{\circ} \mathrm{C}$, foram adicionadas 5 gotas do reagente vermelho de metila em cada tubo. Foram considerados positivos os tubos que apresentaram cor vermelha.

\section{- Teste de utilização do Citrato}

Tubos com ágar citrato de Simmons inclinado foram inoculados e incubados por $24-48 \mathrm{~h}$ a $(35-37)^{\circ} \mathrm{C}$. Após a incubação, foram considerados positivos os tubos com crescimento microbiano e mudança da cor do meio, de verde para azul, devido à mudança do $\mathrm{pH}$.

Foram considerados positivos para Escherichia coli, os tubos a partir dos quais houve confirmação da presença da bactéria, ou seja: bastonetes Gram-negativos, curtos e não esporulados, Indol (+), VM (+), VP (-) e Citrato (-). Com auxílio da Tabela do NMP (ANEXO C), foi calculado o NMP de E.coli por $\mathrm{mL}$ de leite. O esquema da análise de coliformes está representado na Figura 9. 

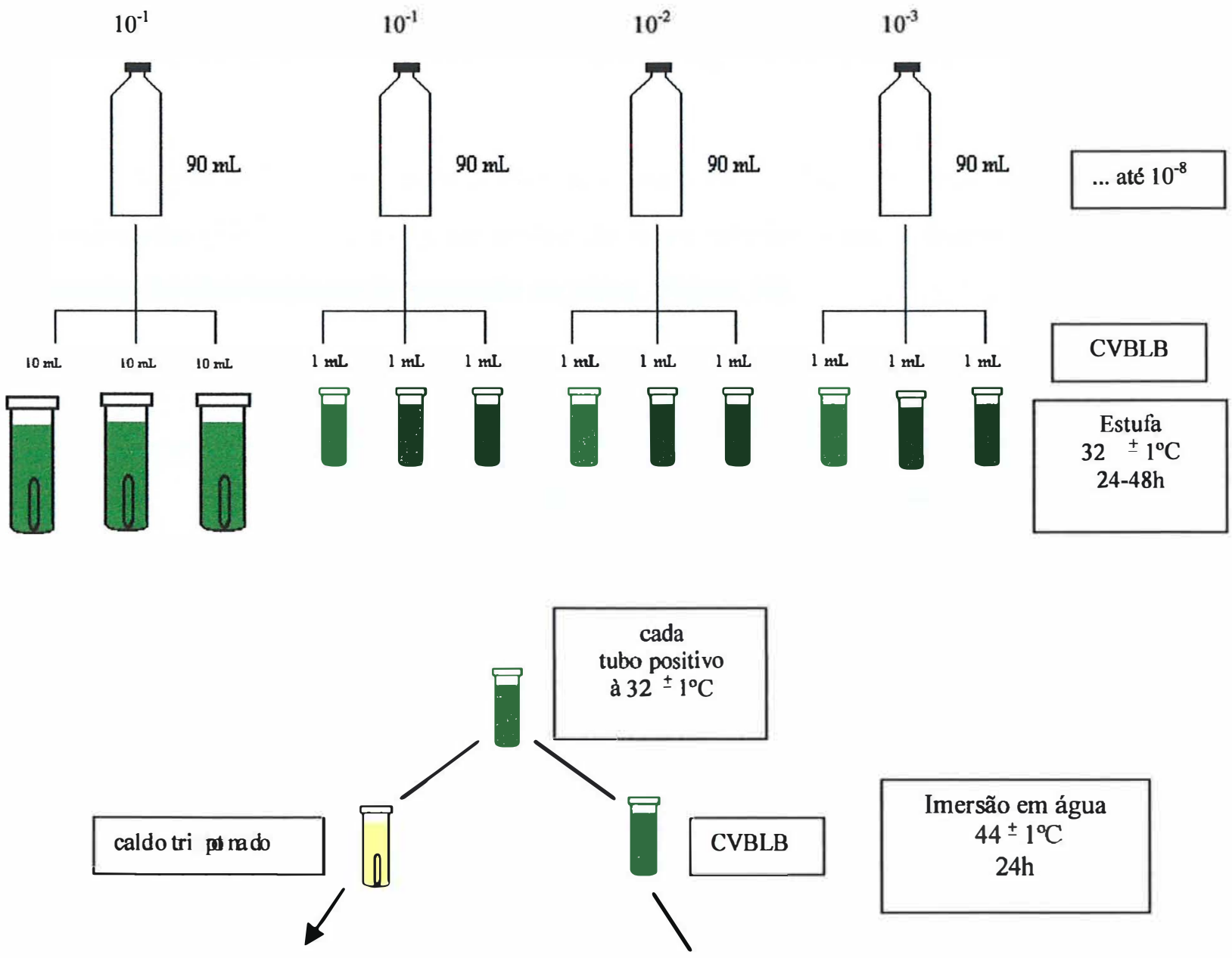

Teste do Indol

tubos positivos

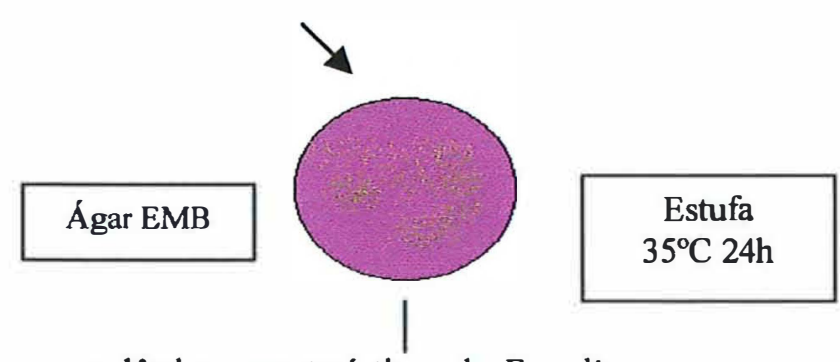

colônias características de $E$. coli<smiles>C[14CH2]</smiles>

Gram

Teste de Citrato

Prova de VP

Prova de VM

Figura 9 - Esquema do procedimento analítico de coliformes pelo método convencional. 


\subsubsection{Contagem de coliformes totais e Escherichia coli em Petrifilm ${ }^{\circledR}$ EC}

As placas Petrifilm ${ }^{\circledR}$ para coliformes foram inoculadas com $1 \mathrm{~mL}$ das diluições selecionadas $\left(10^{-2}, 10^{-3}\right.$ e $\left.10^{-4}\right)$, no centro do filme inferior. Com o difusor plástico, a amostra foi distribuída uniformemente na placa (Figura 10).
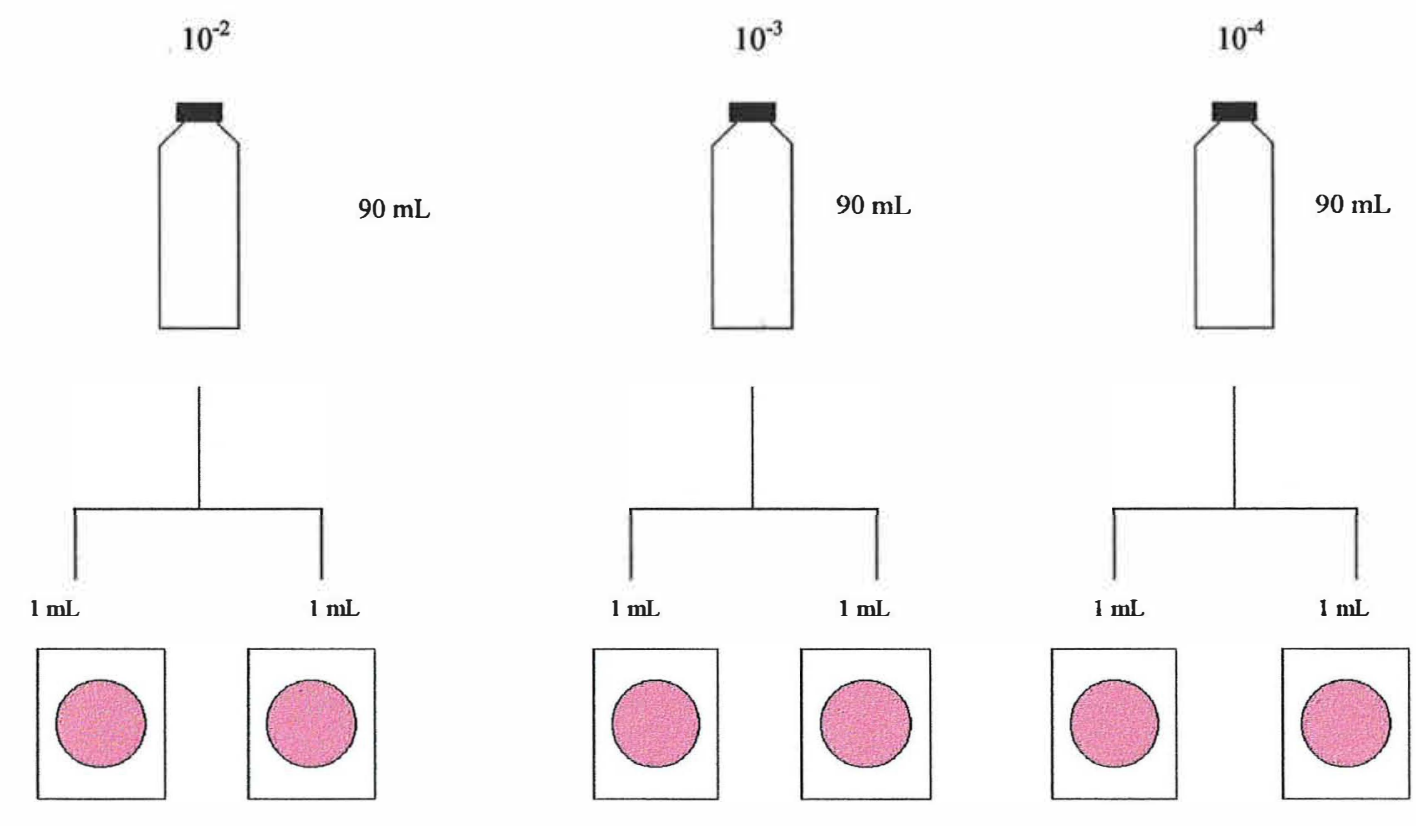

$$
\text { Petrifilm }{ }^{\circledR} \mathrm{EC}
$$$$
\text { Estufa }(32 \pm 1)^{\circ} \mathrm{C}
$$

$24-48 \mathrm{~h}$

Figura 10 - Esquema analítico para coliformes totais e E. coli em Petrifilm ${ }^{\circledR}$ EC.

Após a solidificação, as placas foram incubadas, com a superfície transparente voltada para cima. A incubação foi a $32 \pm 1^{\circ} \mathrm{C}$ por $24 \mathrm{~h}$, quando foi realizada a contagem de coliformes totais (total de colônias vermelhas e azuis associadas com gás). As placas 
foram novamente incubadas por mais $24 \mathrm{~h}$, quando foi feita uma nova contagem de $E$. coli, de acordo com os procedimentos de análise recomendados pelo fabricante (Método Oficial $A O A C^{\circledR}$ 991.14). Este método recomenda a utilização de uma única placa Petrifilm ${ }^{\circledR} \mathrm{EC}$, incubada a $35^{\circ} \mathrm{C}$ por $24 \mathrm{~h}$, para a contagem de coliformes totais e mais $24 \mathrm{~h}$ adicionais, para verificação de um possível crescimento de novas colônias de $E$. coli.

As contagens das colônias foram em contador de colônias tipo Quebec. Os resultados foram obtidos pela média aritmética das UFC da duplicata, multiplicada pelo inverso da diluição. De todas as placas Petrifilm ${ }^{\circledR} \mathrm{EC}$ nas quais foi feita contagem de colônias de E. coli, foram coletadas colônias típicas dessa bactéria, ao acaso, e inoculadas em CVBLB para submetê-las à análise convencional para confirmação de $E$. coli (NMP tubos múltiplos e testes bioquímicos de IMViC).

\subsubsection{Contagem de coliformes totais e Escherichia coli em Simplate ${ }^{\circledR} \mathrm{CEc}$}

O substrato fluorogênico do SimPlate ${ }^{\circledR} \mathrm{CEc}$ foi preparado da mesma forma que o descrito para mesófilos (3.2.2.3.). A técnica de distribuição da amostra e do meio também foi idêntica, porém as diluições empregadas foram de $10^{-2}$ a $10^{-4}$. A incubação foi a $(32 \pm 1)^{\circ} \mathrm{C}$ por $24 \mathrm{~h}$.

De acordo com as instruções de uso do SimPlate ${ }^{\circledR} \mathrm{CEc}$, as cavidades que apresentam coloração púrpura, a olho nu, são consideradas positivas para coliformes totais e aquelas que fluorescem sob ação de UV $(365 \mathrm{~nm})$ são positivas para E. coli. Seguindo essa recomendação, após a incubação, procedeu-se a contagem e o NMP foi determinado pela tabela fornecida pelo fabricante (ANEXO A). Os resultados representam a média aritmética da duplicata, multiplicada pelo fator de diluição. 


\subsection{Análise estatística}

Das 31 amostras analisadas de leite cru, 30 foram consideradas como blocos na avaliação estatística da comparação dos métodos para contagem de microrganismos aeróbios mesófilos e 27 para a contagem de coliformes totais. Os resultados não utilizados na avaliação estatística excederam a mais alta diluição.

As contagens de microrganismos foram transformadas em logaritmo de base 10 . Foi utilizada análise de regressão linear simples para a comparação dos métodos (SAS, 1996). Análise de regressão é um sistema frequentemente usado para descrever relação entre dois métodos (MacAllister et al., 1987). Para esta análise estatística, os critérios tradicionais de equivalência entre dois métodos são coeficiente angular próximo de 1,0; coeficiente linear próximo de 0,0 e coeficiente de correlação > 0,9 (Matner et al., 1990).

Foi feito o teste $\mathrm{F}$ da Análise de Variância e os métodos foram comparados através do teste de Tukey utilizando-se o programa Statistical Analysis System (SAS, 1996). 


\section{RESULTADOS E DISCUSSÃO}

$\mathrm{Na}$ Tabela 1 estão apresentadas as contagens de bactérias aeróbias mesófílas totais, obtidas pelos métodos convencional (PCA), Petrifilm ${ }^{\circledR}$ AC e SimPlate ${ }^{\circledR} \mathrm{TPC}$, com os respectivos valores transformados em $\log _{1}$.

A Tabela 3 mostra os resultados das contagens de coliformes totais obtidas pelos métodos convencional, Petrifilm ${ }^{\circledR}$ EC e SimPlate ${ }^{\circledR}$ CEc. Também nesta tabela aparecem os valores transformados em $\log _{10}$. Na Tabela 5 estão os resultados das contagens de coliformes fecais e $E$. coli pelos três métodos.

Os resultados apresentados são as médias dos resultados da duplicata, com exceção dos resultados das análises de coliformes totais feitas pelo método dos tubos múltiplos.

Nas Tabelas 6 e 7, encontradas no ANEXO D, podem ser observadas as análises de variância com o teste $\mathrm{F}$ e seus respectivos níveis descritivos.

Nas Figuras 11, 12, 13, 15, 16 e 17 estão os diagramas de dispersão. As Figuras 14 e 18 mostram histogramas com a comparação dos resultados das médias obtidas pelos três métodos. 


\subsection{Aeróbios mesófilos}

Tabela 1. Dados obtidos na contagem total de aeróbios mesófilos em leite cru, pelos métodos convencional (PCA), Petrifilm ${ }^{\circledR}$ AC e SimPlate ${ }^{\circledR}$ TPC e logaritmo dos dados.

\begin{tabular}{|c|c|c|c|c|c|c|}
\hline \multirow[t]{2}{*}{ Coletas } & \multicolumn{2}{|c|}{$\begin{array}{l}\text { Método convencional } \\
\text { (PCA) }\end{array}$} & \multicolumn{2}{|c|}{ Petrifilm ${ }^{\circledR} \mathrm{AC}$} & \multicolumn{2}{|c|}{ SimPlate ${ }^{\circledR} \mathrm{TPC}$} \\
\hline & $\mathrm{UFC} / \mathrm{mL}$ & $\mathrm{Log} \mathrm{UFC} / \mathrm{mL}$ & $\mathrm{UFC} / \mathrm{mL}$ & Log UFC/mL & $\mathrm{NMP} / \mathrm{mL}$ & Log NMP/mL \\
\hline 1 & $1,53 \times 10^{5}$ & 5,18 & $1,38 \times 10^{5}$ & 5,14 & $1,84 \times 10^{5}$ & 5,26 \\
\hline 2 & $7,80 \times 10^{5}$ & 5,89 & $8,30 \times 10^{5}$ & 5,92 & $7,10 \times 10^{5}$ & 5,85 \\
\hline 3 & $3,95 \times 10^{6}$ & 6,60 & $3,85 \times 10^{6}$ & 6,59 & $2,50 \times 10^{6}$ & 6,40 \\
\hline 4 & $1,42 \times 10^{5}$ & 5,15 & $1,10 \times 10^{5}$ & 5,04 & $1,48 \times 10^{5}$ & 5,17 \\
\hline 5 & $1,20 \times 10^{6}$ & 6,08 & $1,20 \times 10^{6}$ & 6,08 & $6,30 \times 10^{5}$ & 5,80 \\
\hline 6 & $2,24 \times 10^{5}$ & 5,35 & $2,10 \times 10^{5}$ & 5,32 & $2,05 \times 10^{5}$ & 5,31 \\
\hline 7 & $9,95 \times 10^{5}$ & 6,00 & $1,04 \times 10^{6}$ & 6,02 & $7,30 \times 10^{5}$ & 5,86 \\
\hline 8 & $1,70 \times 10^{6}$ & 6,23 & $1,75 \times 10^{6}$ & 6,24 & $1,96 \times 10^{6}$ & 6,29 \\
\hline 9 & $1,46 \times 10^{6}$ & 6,16 & $1,70 \times 10^{6}$ & 6,23 & $1,66 \times 10^{6}$ & 6,22 \\
\hline 10 & $2,61 \times 10^{5}$ & 5,42 & $2,71 \times 10^{5}$ & 5,43 & $3,89 \times 10^{5}$ & 5,59 \\
\hline 11 & $1,00 \times 10^{6}$ & 6,00 & $1,08 \times 10^{6}$ & 6,04 & $8,60 \times 10^{5}$ & 5,93 \\
\hline 12 & $7,70 \times 10^{6}$ & 6,89 & $7,40 \times 10^{6}$ & 6,87 & $7,38 \times 10^{6}$ & 6,87 \\
\hline 13 & $9,20 \times 10^{5}$ & 5,96 & $8,90 \times 10^{5}$ & 5,95 & $8,40 \times 10^{5}$ & 5,92 \\
\hline 14 & $3,05 \times 10^{5}$ & 5,48 & $5,40 \times 10^{5}$ & 5,73 & $3,90 \times 10^{5}$ & 5,59 \\
\hline 15 & $2,80 \times 10^{5}$ & 5,45 & $2,80 \times 10^{5}$ & 5,45 & $3,40 \times 10^{5}$ & 5,53 \\
\hline 16 & $2,34 \times 10^{6}$ & 6,37 & $2,78 \times 10^{6}$ & 6,44 & $4,70 \times 10^{6}$ & 6,67 \\
\hline 17 & $2,29 \times 10^{7}$ & 7,36 & $2,31 \times 10^{7}$ & 7,36 & $2,48 \times 10^{7}$ & 7,39 \\
\hline 18 & $9,00 \times 10^{5}$ & 5,95 & $8,40 \times 10^{5}$ & 5,92 & $9,50 \times 10^{5}$ & 5,98 \\
\hline 19 & $5,50 \times 10^{5}$ & 5,74 & $5,55 \times 10^{5}$ & 5,74 & $5,10 \times 10^{5}$ & 5,71 \\
\hline 20 & $1,02 \times 10^{6}$ & 6,01 & $1,03 \times 10^{6}$ & 6,01 & $8,30 \times 10^{5}$ & 5,92 \\
\hline 21 & $1,54 \times 10^{7}$ & 7,19 & $2,59 \times 10^{7}$ & 7,41 & $3,12 \times 10^{7}$ & 7,49 \\
\hline 22 & $4,95 \times 10^{6}$ & 6,69 & $5,55 \times 10^{6}$ & 6,74 & $6,60 \times 10^{6}$ & 6,82 \\
\hline 23 & $1,66 \times 10^{5}$ & 5,22 & $1,67 \times 10^{5}$ & 5,22 & $1,72 \times 10^{5}$ & 5,24 \\
\hline 24 & $1,77 \times 10^{7}$ & 7,25 & $1,61 \times 10^{7}$ & 7,21 & $1,96 \times 10^{7}$ & 7,29 \\
\hline 25 & $9,05 \times 10^{6}$ & 6,96 & $6,75 \times 10^{5}$ & 6,83 & $6,00 \times 10^{6}$ & 6,78 \\
\hline 26 & $2,71 \times 10^{7}$ & 7,43 & $2,99 \times 10^{7}$ & 7,48 & $4,14 \times 10^{7}$ & 7,62 \\
\hline 27 & $1,22 \times 10^{6}$ & 6,09 & $1,75 \times 10^{6}$ & 6,24 & $2,04 \times 10^{6}$ & 6,31 \\
\hline 28 & $6,55 \times 10^{6}$ & 6,82 & $6,25 \times 10^{6}$ & 6,80 & $2,40 \times 10^{6}$ & 6,38 \\
\hline 29 & $6,45 \times 10^{5}$ & 5,81 & $6,50 \times 10^{5}$ & 5,81 & $6,60 \times 10^{5}$ & 5,82 \\
\hline 30 & $7,55 \times 10^{5}$ & 5,88 & $7,75 \times 10^{5}$ & 5,89 & $5,90 \times 10^{5}$ & 5,77 \\
\hline
\end{tabular}

Conforme pode ser observado na Tabela 1, 23 das amostras apresentaram contagem total de aeróbios mesófilos acima de 5,0 × $10^{5} \mathrm{UFC} / \mathrm{mL}$, nos três métodos, 
portanto, acima do padrão estabelecido pelo Ministério da Agricultura, para o leite cru tipo B (BRASIL, 1952).

Os coeficientes de correlação $(r)$ obtidos na estatística de regressão indicaram que os três métodos são altamente correlacionados para a contagem de aeróbios mesófilos (Figuras 11, 12 e 13). Como mostram as equações, nestas figuras, os coeficientes angular e linear estão muito próximos de 1,0 e 0,0 respectivamente, indicando equivalência entre os métodos.

Além de altos, os coeficientes de correlação entre os métodos de contagem de aeróbios mesófilos, foram bem próximos entre si. Quando comparados, o maior coeficiente de correlação e a melhor equação da reta foram obtidos entre o método convencional de contagem em placas e o Petrifilm ${ }^{\circledR} \mathrm{AC}$ (Tabela 2).

Tabela 2. Resumo das comparações estatísticas entre os métodos de plaqueamento em profundidade (PCA), Petrifilm ${ }^{\circledR} \mathrm{AC}$ e SimPlate ${ }^{\circledR} \mathrm{TPC}$ para contagem de aeróbios mesófilos em leite cru.

\begin{tabular}{cccc}
\hline $\begin{array}{c}\text { Medida de } \\
\text { performance }\end{array}$ & $\begin{array}{c}\text { Plaqueamento com } \\
\text { PCA x Petrifilm }{ }^{\circledR} \mathrm{AC}\end{array}$ & $\begin{array}{c}\text { Plaqueamento com } \\
\text { PCA x SimPlate }{ }^{\circledR} \mathrm{TPC}\end{array}$ & $\begin{array}{c}\text { SimPlate }{ }^{\circledR} \mathrm{TPC} \\
\text { x Petrifilm }\end{array}{ }^{\circledR} \mathrm{AC}$ \\
\hline Coeficiente de & 0,993 & 0,972 & 0,980 \\
correlação & 1,0102 & 1,0011 & 0,9921 \\
Coeficiente angular & $-0,0441$ & $-0,0005$ & 0,0361 \\
Coeficiente linear & 30 & 30 & 30 \\
Número de & 30 & & \\
amostras & &
\end{tabular}

O teste de médias revelou que não houve diferença significativa entre os resultados obtidos nos três métodos de contagem de aeróbios mesófilos a $1 \%$ de probabilidade (Figura 14). 


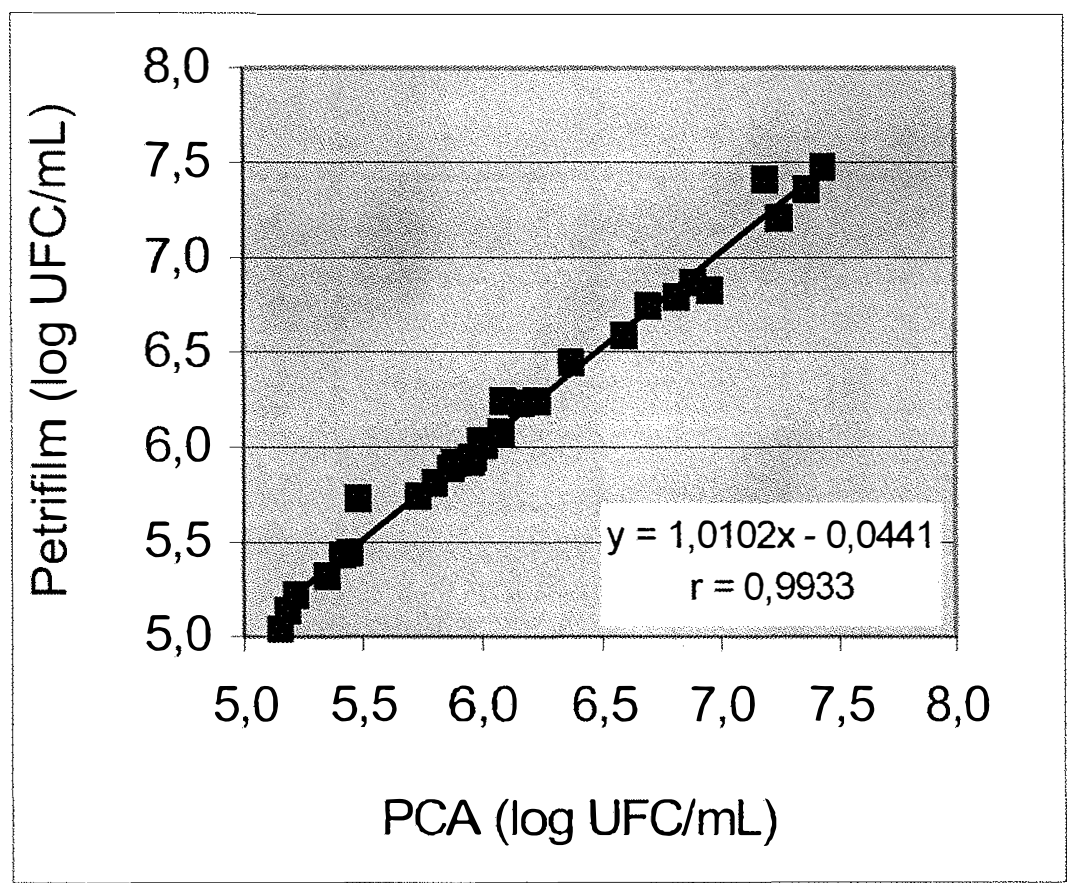

Figura 11 - Dispersão dos resultados das contagens de microrganismos aeróbios mesófilos em leite cru, obtidos pelos métodos de contagem em placas com PCA e Petrifilm ${ }^{\circledR} \mathrm{AC}$. 


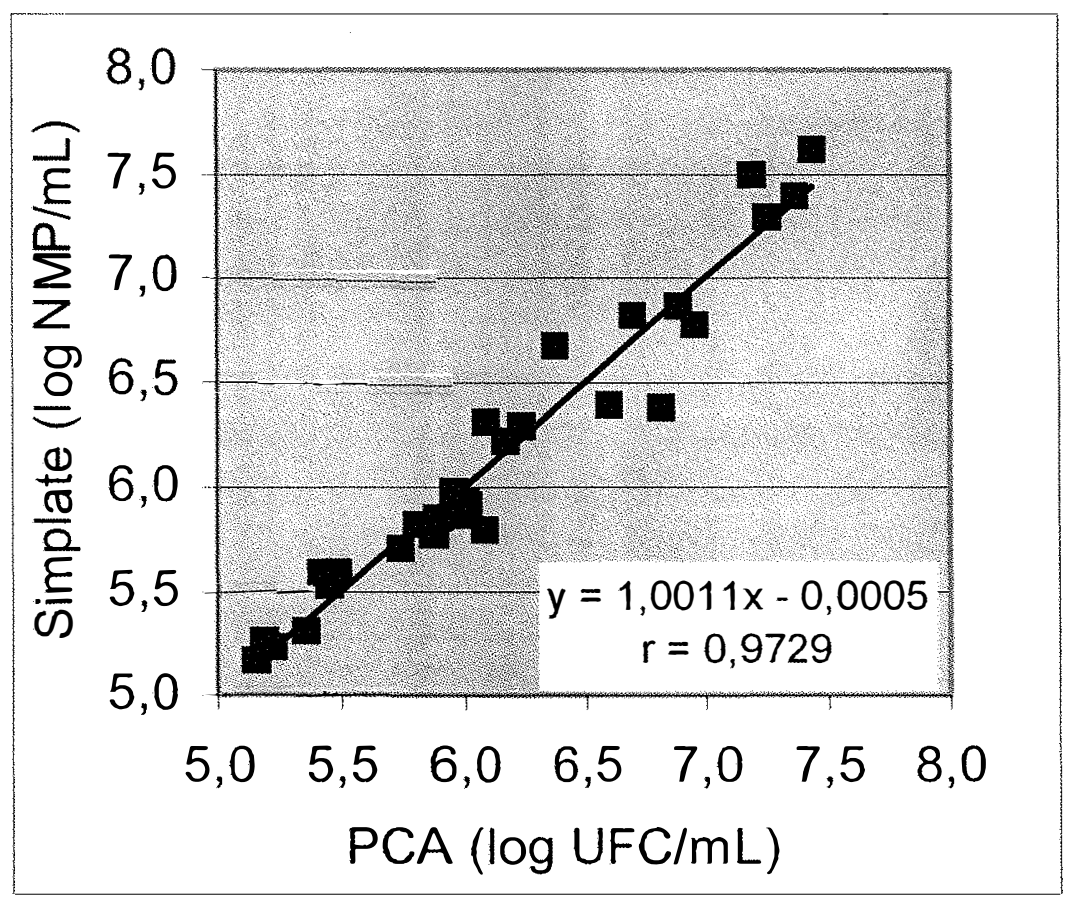

Figura 12 - Dispersão dos resultados das contagens de microrganismos aeróbios mesófilos em leite cru, obtidos pelos métodos de contagem em placas com PCA e SimPlate ${ }^{\circledR}$ TPC. 


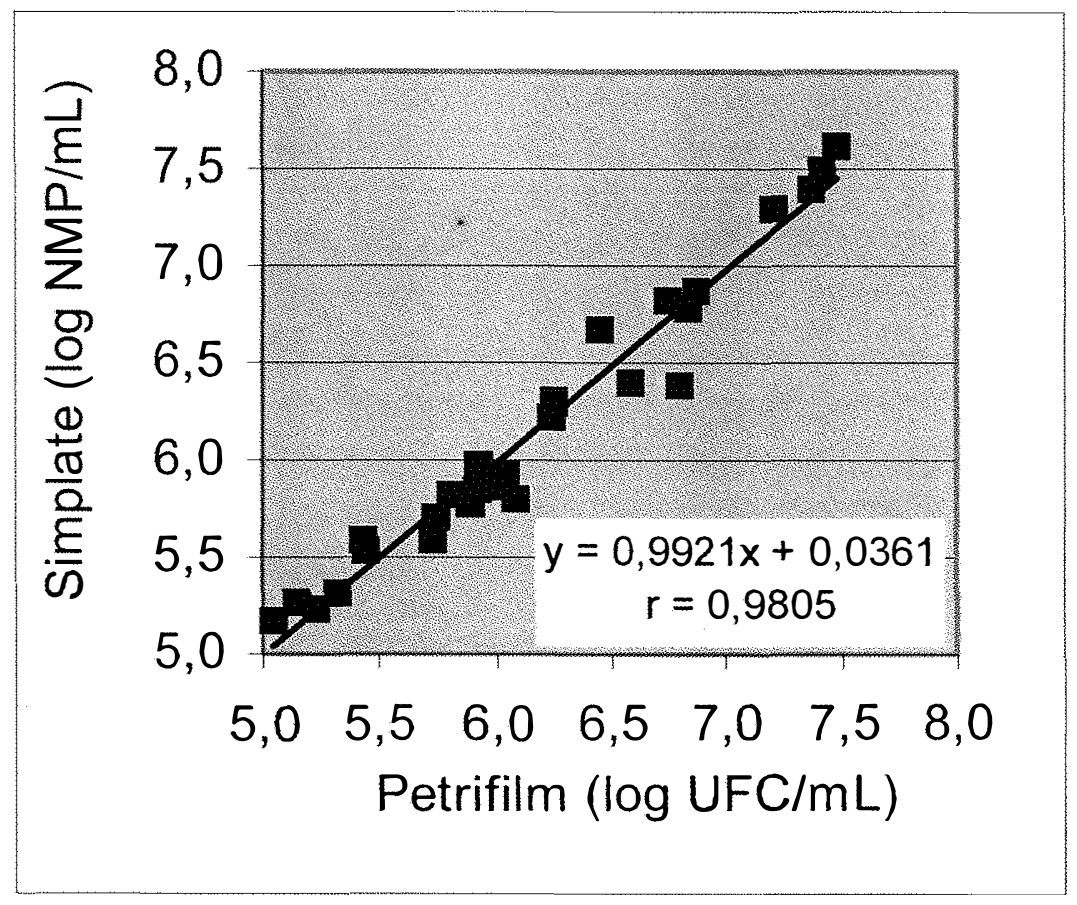

Figura 13 - Dispersão dos resultados das contagens de microrganismos aeróbios mesófilos em leite cru, obtidos em Petrifilm ${ }^{\circledR} \mathrm{AC}$ e SimPlate ${ }^{\circledR} \mathrm{TPC}$. 


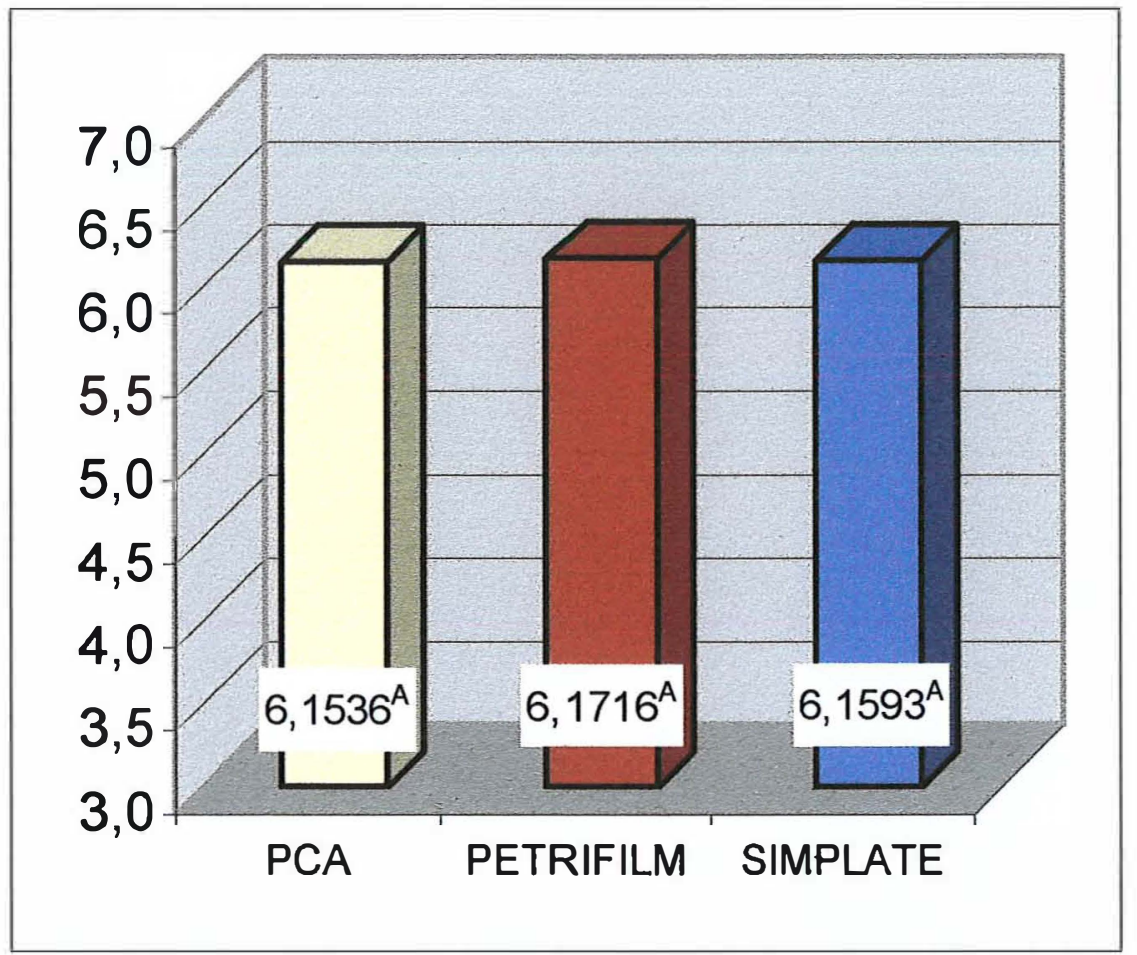

Figura 14 - Comparação entre as médias obtidas nas contagens de aeróbios mesófilos pelos métodos convencional (PCA), Petrifilm ${ }^{\circledR}$ AC e SimPlate ${ }^{\circledR}$ TPC. Médias seguidas da mesma letra maiúscula não diferem entre si pelo teste de Tukey ao nível de probabilidade de $1 \%$. 
O tempo de incubação das placas Petrifilm ${ }^{\circledR} \mathrm{AC}$ foi de $48 \mathrm{~h}$, conforme recomendação de uso desse sistema. Franco (1994), analisando 4 tipos de alimentos, utilizou períodos de incubação de 24 e $48 \mathrm{~h}$ para as placas Petrifilm ${ }^{\circledR}$ para aeróbios totais e concluiu que o tempo de incubação não deve ser reduzido para 24h, pois as contagens em $48 \mathrm{~h}$ foram significativamente mais altas do que aquelas obtidas com $24 \mathrm{~h}$ de incubação.

Desde que foram desenvolvidas, as placas Petrifilm ${ }^{\circledR}$ vêm sendo avaliadas e comparadas com outros métodos, para diversos tipos de alimentos. Na literatura, comparações entre Petrifilm ${ }^{\circledR} \mathrm{AC}$ e o método convencional de contagem de microrganismos aeróbios em placas também apresentaram bons resultados, quando o produto analisado foi leite cru. Ginn et al (1984) obtiveram coeficiente de correlação igual a 0,95 entre os dois métodos. Bishop \& Juan (1988) encontraram $r=0,971$, inclinação da reta 1,002 e intercepto $-0,117$ e constataram que as placas Petrifilm ${ }^{\circledR} \mathrm{AC}$ são uma alternativa viável ao método convencional. Também com leite cru, Chain \& Fung (1991), compararam o Petrifilm ${ }^{\circledR} \mathrm{AC}$ com o método convencional de contagem de aeróbios mesófilos e encontraram $r=0,99$. Resultados semelhantes $(r=0,98)$ foram descritos por Carvalho (2001) e Hayes et al. (2001), que obtiveram $r=0,94$ entre o Petrifilm ${ }^{\circledR} \mathrm{AC}$ e o método convencional de contagem em placas.

Ainda com respeito ao leite cru, (Piton \& Grappin, 1991) considerando que os estudos realizados até então haviam sido com amostras artificialmente contaminadas, realizaram um estudo de comparação entre o Petrifilm ${ }^{\circledR} \mathrm{AC}$ e o método preconizado pela IDF, com a participação de 14 laboratórios. Os resultados revelaram que a enumeração de aeróbios mesófilos em Petrifilm ${ }^{\circledR} \mathrm{AC}$ foi $10 \%$ inferior à convencional.

Num estudo colaborativo de comparação do Petrifilm ${ }^{\circledR}$ com os métodos convencionais para contagem de bactérias aeróbias totais em placas de Petri e de coliformes em VRBA, em leite cru e pasteurizado, verifica-se que os resultados obtidos pelos dois métodos não diferem estatisticamente dos convencionais (Ginn et al.,1986). A partir dos resultados obtidos no referido estudo, e na pesquisa coordenada por Curiale et 
al. (1989), com participação de 11 laboratórios, os quais analisaram cinco produtos lácteos inoculados com diferentes concentrações de bactérias aeróbias e coliformes, o método Petrifilm ${ }^{\circledR}$ foi aprovado em Ação Final pela AOAC, para contagem de aeróbios totais e coliformes em laticínios (method 986.33 e method 989.10).

Curiale et al. (1990) apresentam outro estudo colaborativo de comparação entre o Petrifilm ${ }^{\circledR} \mathrm{AC}$ e o método convencional, com 6 tipos de alimentos diversos (farinhas, nozes, camarão cru, condimentos, carne de perú moída e congelada e vegetais). Esses alimentos foram escolhidos por apresentarem fatores com possibilidade de interferência nos resultados como partículas de alimentos, presença de microrganismos que liquefazem géis, microrganismos que crescem espalhando-se pelas placas e contaminação alta por bolores. Os resultados da pesquisa indicaram equivalência entre o Petrifilm ${ }^{\circledR} \mathrm{AC}$ e o método padrão.

Com leite pasteurizado, integral e desnatado, McAllister et al. (1987) encontraram altas correlações entre o Petrifilm ${ }^{\circledR} \mathrm{AC}$ e o método convencional $(r=0,99)$. Para avaliação de carne de frango, Bailey \& Cox (1987) encontraram boa correlação entre o método convencional e Petrifilm ${ }^{\circledR} \mathrm{AC}(r=0,93)$. Blackburn et al. (1996), avaliando o Petrifilm ${ }^{\circledR}$ para contagem de mesófilos em comparação com o método padrão, para vários tipos de alimentos, também encontraram alta correlação $(0,989)$.

$\mathrm{O}$ coeficiente de correlação entre o PCA e o Petrifílm ${ }^{\circledR} \mathrm{AC}$ obtido no presente estudo $(r=0,9933)$ foi superior àqueles encontrados por Beloti et al (2000) em leite pasteurizado. Esses autores, buscando encontrar as razões das contagens em Petrifilm ${ }^{\circledR} \mathrm{AC}$ inferiores ao método convencional para o leite pasteurizado produzido no Brasil, verificaram que o que influenciou nos resultados foi a qualidade do leite: para os leites tipos A, B e C, obtiveram coeficientes de correlação entre os métodos de 0,8518 ; 0,7697 e 0,6926, respectivamente. Verificaram que os dois maiores grupos de microrganismos remanescentes à pasteurização são bactérias que vêm do leite cru: cocobacilos e cocos Gram positivos e termodúricos e explicam que, quanto pior a condição de higiene na obtenção do leite, maior a freqüência desses microrganismos que, em sua maioria, não reagem com o TTC. Afirmam que, dessa maneira, as colônias 
não ficam visíveis nas placas Petrifilm ${ }^{\circledR}$ AC. Além disso, suspeitam que o TTC, que não tem sua concentração divulgada nas placas Petrifilm ${ }^{\circledR}$, possa causar inibição dos microrganismos, já injuriados pela pasteurização. Concluem que, quanto piores as condições de higiene, maiores as contagens microbianas, maior a freqüência de microrganismos não redutores e sensíveis ao TTC e maiores as diferenças entre os resultados obtidos no Petrifilm ${ }^{\circledR} \mathrm{AC}$ e no método padrão. Os autores comentam que essa diferença não aparece no leite cru porque a microbiota é composta de uma série de outros microrganismos, sendo os não redutores, a minoria. Os resultados do presente estudo reforçam essa explicação, pois, na comparação entre o método convencional e o Petrifilm ${ }^{\circledR} \mathrm{AC}$, além dos parâmetros estatísticos indicarem resultados excelentes, mostrando que os resultados encontrados nos dois métodos foram equivalentes, as médias dos resultados obtidos em Petrifilm ${ }^{\circledR} \mathrm{AC}$ foram superiores aos obtidos em PCA em 18 das 30 amostras. Somente para 10 amostras, o plaqueamento convencional resultou em contagens superiores as do Petrifilm ${ }^{\circledR} \mathrm{AC}$. Duas amostras tiveram médias idênticas pelos dois métodos (Tabela 1).

Estudando bactérias termodúricas, Byrne \& Bishop (1991) avaliaram o desempenho do Petrifilm ${ }^{\circledR}$ AC para enumeração desse grupo de microrganismos em leite, comparado ao da contagem tradicional em ágar. Verificaram que, para Bacillus cereus, Corynebacterium, Streptococcus e algumas espécies de Micrococcus, a enumeração não teve diferença estatística significativa, sendo o método Petrifilm ${ }^{\circledR}$ conveniente para sua enumeração. Porém, algumas espécies de Micrococcus produziram menos colônias em Petrifilm ${ }^{\circledR} \mathrm{AC}$ do que no ágar após a pasteurização do leite em laboratório, com diferença significativa. Esses autores consideraram que, como os micrococos representam uma pequena porcentagem da flora normal do leite cru, não representaria problema se não fossem detectados. No Brasil, a falta de boas práticas higiênicas na produção de leite pode resultar em aumento considerável na concentração de termodúricos no leite cru, típicos de equipamento de ordenha, remanescentes no leite pasteurizado. Falhas ou falta de refrigeração do leite cru favorecem a multiplicação desse grupo de microrganismos (Beloti, 2000). No estudo conduzido por esse autor os micrococos mostraram-se bastante 
sensíveis ao TTC, mesmo quando não foram submetidos a estresse pelo calor. Portanto, se uma grande concentração de termodúricos, micrococos por exemplo, aparecesse no leite cru, poderia ocasionar diferenças nas contagens obtidas pelo método convencional e Petrifilm, já que os micrococos mostram-se sensíveis ao TTC mesmo quando não submetidos ao calor.

Durante a execução do presente trabalho, as contagens de colônias de aeróbios mesófilos em Petrifilm sempre foram feitas com facilidade devido ao quadriculado das placas e à redução do TTC. Foram, no entanto, verificadas algumas variações na intensidade de vermelho das colônias, porém, como os resultados encontrados na enumeração em PCA e no Petrifilm ${ }^{\circledR} \mathrm{AC}$ foram muito próximos, conclui-se que microrganismos não redutores do TTC, como mencionado por Beloti et al. (2000), trabalhando com amostras de leite pasteurizado, aqui não estiveram presentes, pelo menos em número significativo.

Quanto ao SimPlate ${ }^{\circledR}$ TPC, a leitura dos resultados nesse sistema exige bastante atenção, pois, muitas vezes, ocorrem grandes diferenças de intensidade de fluorescência deixando dúvida sobre a positividade. De acordo com as recomendações de uso do sistema, qualquer fluorescência deve ser considerada como positiva. $O$ fato de não ser divulgada a composição do SimPlate ${ }^{\circledR}$ TPC gera incertezas sobre como determinado alimento ou tipos de microrganismos presentes irão reagir com o substrato. Sobre esse aspecto, Beloti (2000) explica que a capacidade dos microrganismos produzirem fluorescência é variável, podendo depender da concentração de células viáveis nas cavidades do SimPlate ${ }^{\circledR}$ TPC e que é possivel que um determinado microrganismo, ou grupo de microrganismos, produza metabólitos que inibam a fluorescência, ou mesmo que metabolizem o indicador fluorescente. Em sua pesquisa, constatou que micrococos e lactococos parecem demorar $48 \mathrm{~h}$ para produzir fluorescência, podendo não produzí-la. Cocobacilos Gram positivos e negativos, leveduras e bacilos Gram positivos são variáveis, mas tendem a produzir fluorescência fraca e tardia. Cocos Gram positivos, exceto micrococos e lactococos, bacilos Gram negativos e actinomicetos geram fluorescência em $24 \mathrm{~h}$. 
Tavolaro (2000) reporta o primeiro relato de estudo da performance do SimPlate ${ }^{\circledast}$ (Townsend et al. ${ }^{6}$, sem data). No referido estudo, as relações obtidas entre SimPlate ${ }^{\circledR}$ e o método convencional em análises de produtos lácteos foram: $r=0,96$, coeficientes linear e angular -0,39 e 1,07 (obtidos no laboratório IDEXX) e $r=0,9$, coeficientes linear e angular -0,09 e 1,05 (obtidos em laboratórios externos à IDEXX).

Beauchat et al. (1998) relatam um trabalho de comparação do SimPlate ${ }^{\circledR}$ TPC com Petrifilm, Redigel e o método convencional de contagem total de microrganismos mesófilos utilizando 751 amostras de alimentos diferentes, com a participação de 6 laboratórios, e resultados do método SimPlate ${ }^{\circledR}$ altamente correlacionados com os demais métodos. Valores de $r=0,95$ a 0,98 foram encontrados na comparação entre o SimPlate ${ }^{\circledR}$ TPC (incubado por $48 \mathrm{~h}$ ) e o PCA. Coeficiente de correlação $=0,97$ foi obtido na comparação entre o SimPlate ${ }^{\circledR}$ TPC (incubado por 24h) e o PCA. Os autores consideraram o SimPlate ${ }^{\circledR}$ TPC uma alternativa para substituir o PCA, Petrifilm e Redigel, apesar não ser indicado para alguns alimentos que apresentam atividade enzímica e interferem nos resultados.

Townsend \& Naqui (1998) utilizaram 15 tipos diferentes de alimentos, incluindo leite cru e pasteurizado e obtiveram alto coeficiente de correlação entre os métodos SimPlate ${ }^{\circledR}$ TPC e a contagem de mesófilos em PCA, $(r=0,95)$. Os autores verificaram equivalência entre os métodos também no teste de médias. A média do logaritmo dos resultados e desvio padrão foram comparados, para cada grupo de produto testado, separadamente, e não foram encontradas diferenças significativas entre os métodos convencional e SimPlate ${ }^{\circledR}$.

É importante considerar que nos trabalhos de Townsend \& Naqui (1998) e Beauchat et al. (1998), nos quais o SimPlate ${ }^{\circledR} \mathrm{TPC}$ foi testado para a análise de vários tipos de alimentos, embora o número de amostras tenha sido alto, os coeficientes de correlação foram calculados a partir do conjunto de resultados da análise de todos os alimentos e não para cada grupo, separadamente.

\footnotetext{
${ }^{6}$ TOWNSEND, D.E.; SMITH, K.; NAQUI, A. A new medium designed to detect and quantify the total
} viable count of food after only 24 hours of incubation. (Boletim). IDEXX Laboratories, s.d. $6 \mathrm{p}$. 
Cutolo et al. (1998) confirmaram a eficiência do método SimPlate ${ }^{\circledR}$ TPC quando comparado ao método tradicional de contagem padrão em placas em 28 produtos de diferentes categorias, inclusive lácteos. Para o SimPlate ${ }^{\circledR} \mathrm{TPC}$, foram realizadas contagens com 24 e 48h de incubação. Com os dois períodos de incubação, foi verificada boa correlação entre os métodos convencional e SimPlate ${ }^{\circledR} \mathrm{TPC}(0,96$ e 0,97, respectivamente), semelhante ao encontrado no presente trabalho $(r=0,9729)$.

Tavolaro et al. (1999), comparando contagens de microrganismos aeróbios em leite de cabra pasteurizado e congelado, utilizando Petrifilm ${ }^{\circledR} \mathrm{AC}$ e método convencional, obtiveram $r=0,816$; e para o método convencional e SimPlate ${ }^{\circledR} \mathrm{TPC} r=$ 0,682, ambos inferiores aos obtidos nesta pesquisa. Tavolaro (2000) encontrou um $r$ $=0,3198$ entre SimPlate ${ }^{\circledR}$ TPC e convencional para análise de leite de cabra congelado, ou seja, uma correlação muito fraca, muito inferior à verificada no presente estudo. $\mathrm{O}$ autor aventou a hipótese de que o efeito do congelamento ou fatores não determinados, característicos do leite brasileiro, possam afetar o desempenho do método baseado em atividade enzímica.

Coefientes de correlação inferiores aos obtidos no presente estudo são apresentados por Beloti (2000) que, analisando leite pasteurizado, encontrou baixa correlação entre o SimPlate ${ }^{\circledR}$ TPC incubado por $48 \mathrm{~h}$ e o método de semeadura em PCA $(r=0,7522)$, com um valor de $r^{2}: 0,5659$. Com os resultados do SimPlate ${ }^{\circledR} \mathrm{TPC}$ incubado por $24 \mathrm{~h}$, conforme recomendação do fabricante, a correlação obtida com o método convencional foi ainda menor $(r=0,7186)$. Quando considerou os resultados obtidos por SimPlate ${ }^{\circledR}$ TPC, incubado por $24 \mathrm{~h}$, nos diferentes tipos de leite isoladamente, encontrou $r=0,3858$ para o leite tipo $\mathrm{B}, r=0,4290$ para o tipo $\mathrm{C}$, e para o leite tipo A, não obteve correlação entre os resultados, comparados ao método de semeadura em PCA. Relata que as contagens obtidas por SimPlate ${ }^{\circledR} \mathrm{TPC}$, de uma maneira geral, foram menores do que as observadas no método convencional.

Para o Petrifilm ${ }^{\circledR} \mathrm{AC}$, com exceção dos trabalhos de Beloti et al. (2000), de Tavolaro et al. (1999) e de Tavolaro (2000), todos com leite pasteurizado, nos demais trabalhos citados, as contagens de bactérias aeróbias nas placas Petrifilm ${ }^{\circledR} \mathrm{AC}$ foram 
consideradas equivalentes às contagens obtidas pelo método convencional concordando com os resultados do presente trabalho.

Quanto ao SimPlate ${ }^{\circledR}$ TPC, com exceção dos trabalhos de Tavolaro et al. (1999) e Tavolaro (2000) com leite de cabra pasteurizado, e Beloti (2000) também com leite pasteurizado, os demais trabalhos referidos revelaram boa correlação de resultados entre SimPlate ${ }^{\circledR}$ TPC e o método convencional, concordando com os resultados obtidos neste estudo.

Para a contagem de aeróbios mesófilos, o método convencional apesar de ser de simples execução, exige preparo prévio de meio de cultivo e esterilização de grande quantidade de material. Já o Petrifilm ${ }^{\circledR}$ dispensa preparo de qualquer meio de cultivo, é de uso fácil e ocupa aproximadamente $1 / 10$ de espaço quando comparado ao convencional e ao SimPlate ${ }^{\circledR}$. O Petrifilm ${ }^{\circledR}$ é também o mais conveniente na hora do descarte. A leitura dos resultados em Petrifilm ${ }^{\circledR}$ é feita com bastante facilidade, podendo ser a olho nú, dispensando assim o contador de colônias. É necessário ter cuidado ao colocar o inóculo nas placas Petrifilm ${ }^{\circledR}$ e distribuí-lo com o difusor, a fim de se evitar a formação de bolhas de ar ou espalhamento do material inoculado pela placa, na área não apropriada.

Quanto ao SimPlate ${ }^{\circledR}$, também é de fácil uso e dispensa o preparo de meios de cultivo, além disso, a alta contagem permitida em cada placa (até $738 \mathrm{NMP} / \mathrm{mL}$ ) pode diminuir a necessidade de maiores diluições; por outro lado, em placas que apresentam todas as cavidades positivas não é possível fazer estimativa das contagens. Durante a inoculação, é necessário cuidado para evitar a formação de bolhas de ar nas placas e ter certeza de que todas as cavidades sejam preenchidas com a mistura inóculo-substrato.

Para a contagem total de aeróbios mesófilos em leite cru, o Petrifilm ${ }^{\circledR} \mathrm{AC}$, apesar de não ser um método rápido na obtenção dos resultados, é um método pronto para uso bastante prático e, juntamente com o SimPlate ${ }^{\circledR} \mathrm{TPC}$, apresentou excelentes correlações quando comparado com o método convencional, o que coloca ambos os sistemas como boas alternativas de métodos para essa determinação. 


\subsection{Coliformes}

Tabela 3. Dados obtidos na contagem de coliformes totais pelos métodos convencional (NMP - tubos múltiplos), Petrifilm ${ }^{\circledR}$ EC e Simplate ${ }^{\circledR} \mathrm{CEc}$ e logaritmo dos dados.

\begin{tabular}{ccccccc}
\hline Coletas & \multicolumn{2}{c}{ Método convencional } & \multicolumn{2}{c}{ Petrifilm ${ }^{\circledR}$ EC } & \multicolumn{2}{c}{ Simplate ${ }^{\circledR} \mathrm{CEc}$} \\
& $\mathrm{NMP} / \mathrm{mL}$ & Log NMP/mL & UFC $/ \mathrm{mL}$ & Log UFC/mL & NMP/mL & Log NMP/mL \\
\hline 1 & $4,30 \times 10^{2}$ & 2,63 & $9,50 \times 10^{2}$ & 2,98 & $1,20 \times 10^{3}$ & 3,08 \\
2 & $4,30 \times 10^{4}$ & 4,63 & $1,45 \times 10^{4}$ & 4,16 & $2,20 \times 10^{4}$ & 4,34 \\
3 & $2,40 \times 10^{4}$ & 4,38 & $1,54 \times 10^{4}$ & 4,19 & $2,49 \times 10^{4}$ & 4,40 \\
4 & $1,50 \times 10^{3}$ & 3,18 & $1,30 \times 10^{3}$ & 3,11 & $1,10 \times 10^{3}$ & 3,04 \\
5 & $1,50 \times 10^{3}$ & 3,18 & $1,30 \times 10^{3}$ & 3,11 & $1,60 \times 10^{3}$ & 3,20 \\
6 & $7,50 \times 10^{4}$ & 4,88 & $3,35 \times 10^{4}$ & 4,53 & $4,10 \times 10^{4}$ & 4,61 \\
7 & $1,10 \times 10^{6}$ & 6,04 & $3,15 \times 10^{5}$ & 5,50 & $5,56 \times 10^{5}$ & 5,75 \\
8 & $4,30 \times 10^{4}$ & 4,63 & $1,75 \times 10^{4}$ & 4,24 & $2,70 \times 10^{4}$ & 4,43 \\
9 & $9,30 \times 10^{4}$ & 4,97 & $7,00 \times 10^{4}$ & 4,85 & $1,16 \times 10^{5}$ & 5,06 \\
10 & $4,30 \times 10^{4}$ & 4,63 & $5,80 \times 10^{4}$ & 4,76 & $9,30 \times 10^{4}$ & 4,97 \\
11 & $9,30 \times 10^{3}$ & 3,97 & $7,65 \times 10^{3}$ & 3,88 & $1,02 \times 10^{4}$ & 4,01 \\
12 & $4,30 \times 10^{3}$ & 3,63 & $3,20 \times 10^{3}$ & 3,51 & $6,80 \times 10^{3}$ & 3,83 \\
13 & $1,50 \times 10^{3}$ & 3,18 & $2,40 \times 10^{3}$ & 3,38 & $2,60 \times 10^{3}$ & 3,41 \\
14 & $9,30 \times 10^{4}$ & 4,97 & $4,10 \times 10^{4}$ & 4,61 & $5,40 \times 10^{4}$ & 4,73 \\
15 & $2,30 \times 10^{5}$ & 5,36 & $1,85 \times 10^{5}$ & 5,27 & $2,24 \times 10^{5}$ & 5,35 \\
16 & $4,30 \times 10^{4}$ & 4,63 & $3,45 \times 10^{4}$ & 4,54 & $3,60 \times 10^{4}$ & 4,56 \\
17 & $4,30 \times 10^{4}$ & 4,63 & $4,50 \times 10^{4}$ & 4,65 & $4,50 \times 10^{4}$ & 4,65 \\
18 & $2,30 \times 10^{4}$ & 4,36 & $8,05 \times 10^{4}$ & 4,91 & $8,10 \times 10^{4}$ & 4,91 \\
19 & $9,30 \times 10^{5}$ & 5,97 & $1,78 \times 10^{6}$ & 6,25 & $4,70 \times 10^{6}$ & 6,67 \\
20 & $4,30 \times 10^{5}$ & 5,63 & $2,05 \times 10^{5}$ & 5,31 & $2,24 \times 10^{5}$ & 5,35 \\
21 & $9,30 \times 10^{3}$ & 3,97 & $9,80 \times 10^{3}$ & 3,99 & $1,08 \times 10^{4}$ & 4,03 \\
22 & $9,30 \times 10^{5}$ & 5,97 & $7,80 \times 10^{5}$ & 5,89 & $6,90 \times 10^{5}$ & 5,84 \\
23 & $9,30 \times 10^{5}$ & 5,97 & $6,00 \times 10^{5}$ & 5,78 & $9,80 \times 10^{5}$ & 5,99 \\
24 & $9,30 \times 10^{3}$ & 3,97 & $5,40 \times 10^{3}$ & 3,73 & $9,10 \times 10^{3}$ & 3,96 \\
25 & $2,30 \times 10^{4}$ & 4,36 & $1,02 \times 10^{4}$ & 4,01 & $1,16 \times 10^{4}$ & 4,06 \\
26 & $2,30 \times 10^{4}$ & 4,36 & $8,60 \times 10^{3}$ & 3,93 & $1,40 \times 10^{4}$ & 4,15 \\
27 & $4,30 \times 10^{3}$ & 3,63 & $1,05 \times 10^{4}$ & 4,02 & $1,04 \times 10^{4}$ & 4,02 \\
\hline
\end{tabular}

Apesar de não existir padrão para contagem de coliformes em leite cru no Brasil, contagens excedendo a $100 \mathrm{~mL}^{-1}$, são consideradas evidência de higiene insatisfatória na produção (Bramley \& McKinnon, 1990). Murphy \& Boor (2000) já consideram 50 UFC de coliformes $\mathrm{mL}^{-1}$ como indicativo de problema de higiene na produção do leite. Todas as amostras analisadas excederam esse número (Tabela 3). No Reino Unido, em 1987, a 
Goat Producers Association lançou um plano visando a manutenção da contagem de mesófilos inferior a $20.000 \mathrm{UFC} \mathrm{mL}^{-1}$ e da contagem de coliformes inferior a 10 UFC $\mathrm{mL}^{-1}$, em leite de cabra cru (Stark,1988) ${ }^{7}$, citado por Tavolaro (2000). Na Califórnia, leite cru com contagens de coliformes maiores do que $750 / \mathrm{mL}$ tem seu preço reduzido (Shultz et al., 2002).

Para enumeração de coliformes totais, os coeficientes de correlação entre os métodos avaliados foram considerados bons, conforme mostram as Figuras 15, $16 \mathrm{e}$ 17. O teste de médias também revelou que os resultados obtidos nos três métodos de contagem não diferiram entre si (Figura 18).

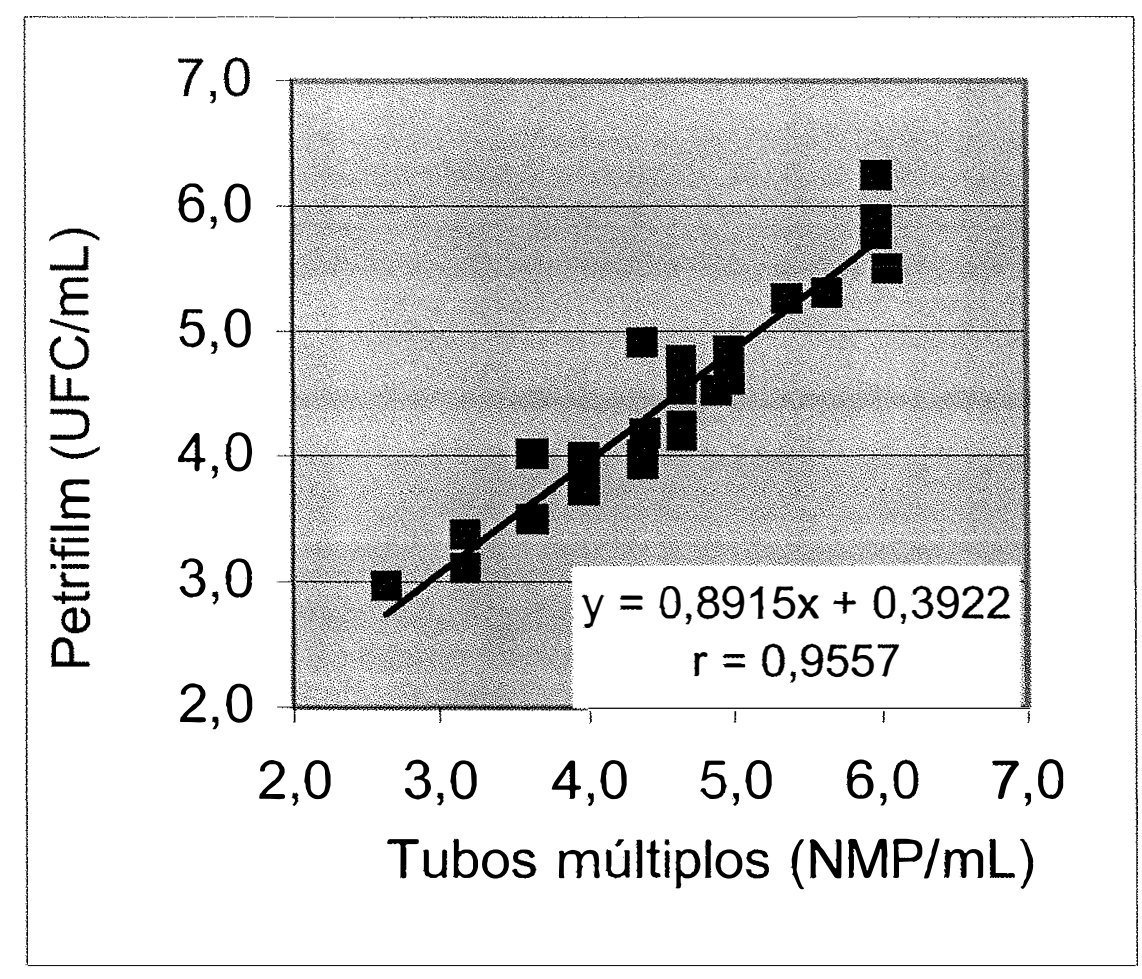

Figura 15 - Dispersão dos resultados das contagens de coliformes totais em leite cru obtidos pelos métodos NMP (tubos múltiplos) e Petrifilm ${ }^{\circledR} \mathrm{EC}$.

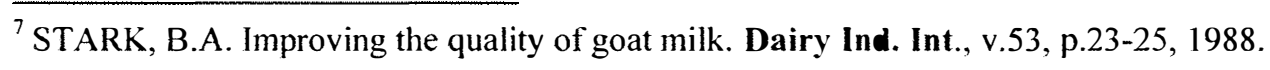




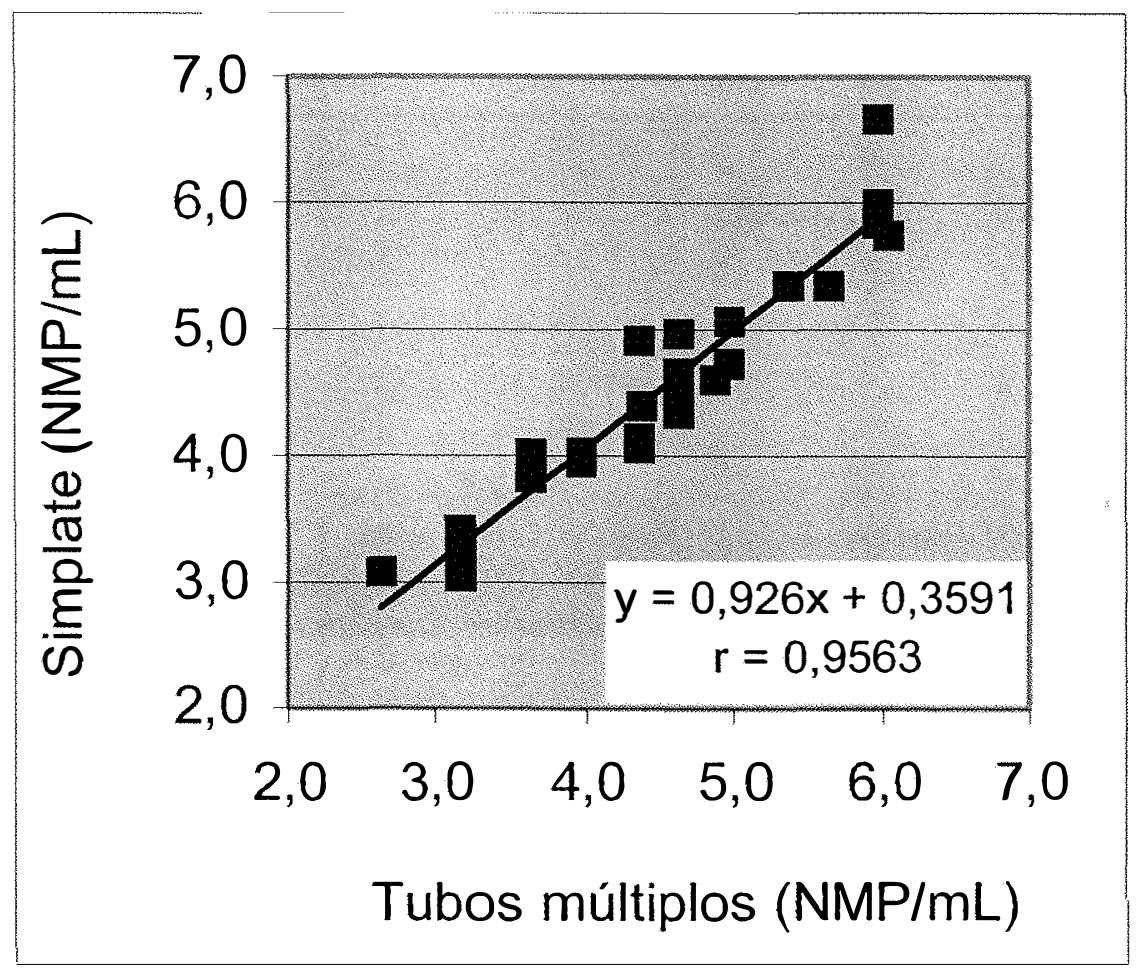

Figura 16 - Dispersão dos resultados das contagens de coliformes totais em leite cru obtidos pelos métodos NMP (tubos múltiplos) e SimPlate ${ }^{\circledR}$ CEc. 


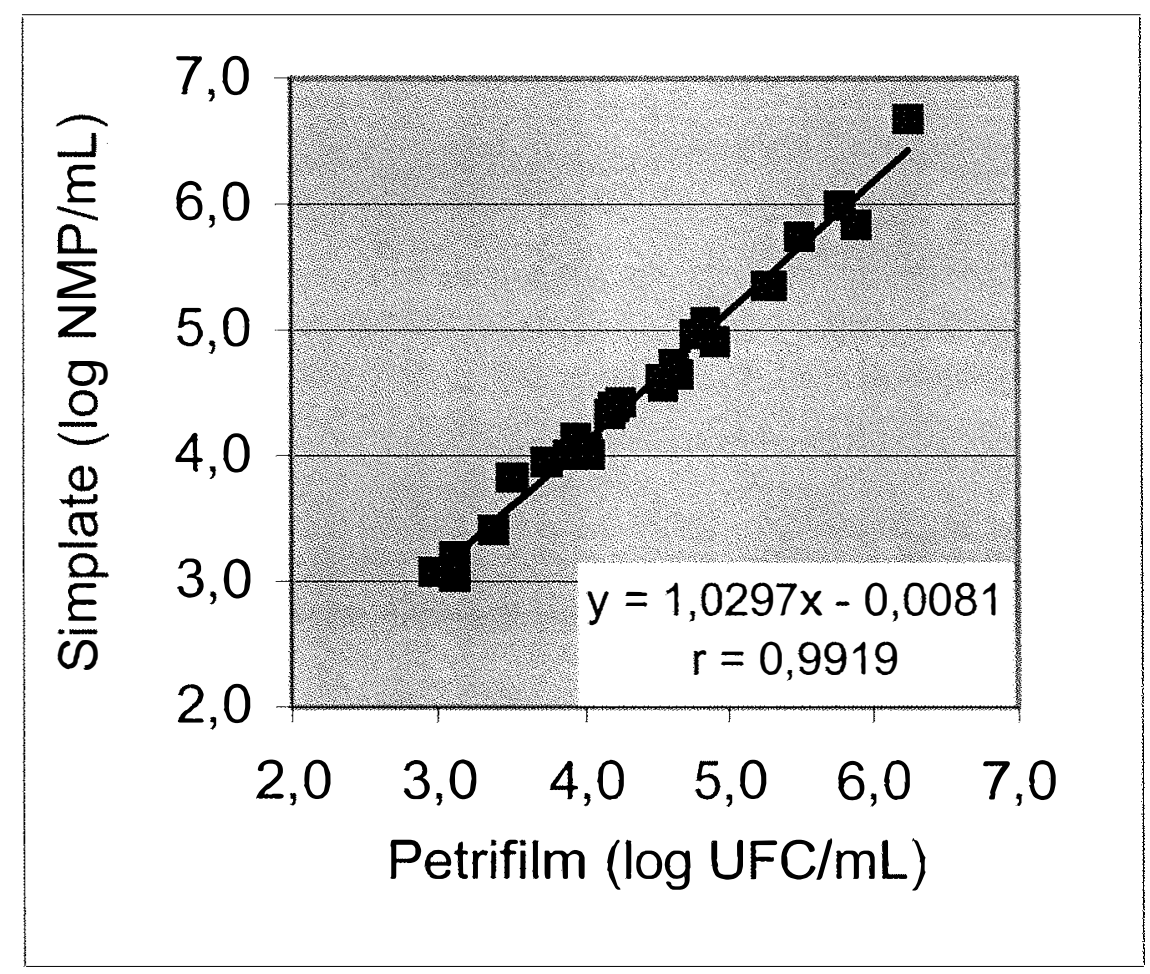

Figura 17 - Dispersão dos resultados das contagens de coliformes totais em leite cru obtidos pelos métodos SimPlate ${ }^{\circledR}$ CEc e Petrifilm ${ }^{\circledR}$ EC. 


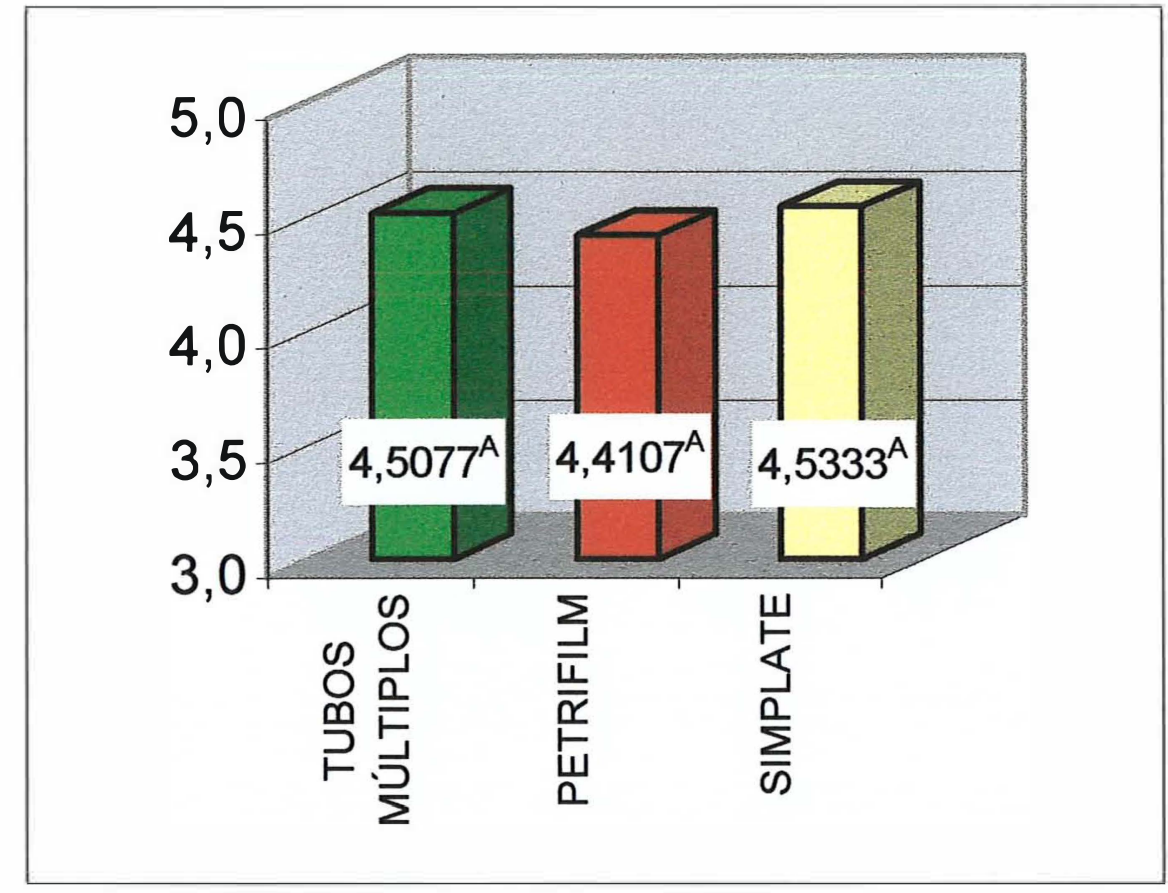

Figura 18 - Comparação entre as médias obtidas nas contagens de coliformes totais pelos métodos dos tubos múltiplos (NMP), Petrifilm ${ }^{\circledR}$ EC e SimPlate ${ }^{\circledR}$ CEc. Médias seguidas da mesma letra maiúscula não diferem entre si pelo teste de Tukey ao nível de probabilidade de $1 \%$. 
Townsend \& Naqui (1998) explicam que o NMP do SimPlate ${ }^{\circledR}$ utiliza o mesmo princípio matemático que o NMP convencional, porém, é mais preciso devido ao grande número de orifícios disponíveis no SimPlate ${ }^{\circledast}$. Assim, o NMP determinado por SimPlate ${ }^{\circledR}$ é altamente correlacionado com métodos de contagens de colônias. Os dados obtidos nesta pesquisa reforçam essa afirmativa: o coeficiente de correlação encontrado entre Petrifilm ${ }^{\circledR} \mathrm{EC}$ e SimPlate ${ }^{\circledR} \mathrm{CEc}$, bem como os valores de intercepto e inclinação foram mais satisfatórios do que aqueles encontrados entre Petrifilm ${ }^{\circledR} \mathrm{EC}$ e NMP dos tubos múltiplos e SimPlate ${ }^{\circledR} \mathrm{CEc}$ e NMP dos tubos múltiplos. A Tabela 4 resume estes parâmetros estatísticos, obtidos pela análise de regressão.

Tabela 4. Resumo das comparações estatísticas entre os métodos NMP (tubos múltiplos), Petrifilm ${ }^{\circledR}$ EC e SimPlate ${ }^{\circledR} \mathrm{CEc}$ para contagem de coliformes totais em leite cru.

\begin{tabular}{cccc}
\hline $\begin{array}{c}\text { Medida de } \\
\text { performance }\end{array}$ & $\begin{array}{c}\text { Tubos múltiplos x } \\
\text { Petrifilm }{ }^{\circledR} \mathrm{EC}\end{array}$ & $\begin{array}{c}\text { Tubos múltiplos x } \\
\text { SimPlate }{ }^{\circledR} \mathrm{Cec}\end{array}$ & $\begin{array}{c}\text { SimPlate }{ }^{\circledR} \mathrm{Cec} \mathrm{x} \\
\text { Petrifilm }{ }^{\circledR} \mathrm{EC}\end{array}$ \\
\hline $\begin{array}{c}\text { Coeficiente de } \\
\text { correlação }\end{array}$ & 0,9557 & 0,9563 & 0,9919 \\
Coeficiente angular & 0,8915 & 0,9260 & 1,0297 \\
Coeficiente linear & 0,3922 & 0,3591 & 0,0081 \\
Número de & & & 27 \\
amostras & 27 & 27 & 27 \\
\hline
\end{tabular}

Para contagem de E. coli não foi possível o cálculo do coeficiente de correlação entre os métodos avaliados, devido à obtenção de um baixo número de resultados possíveis de serem considerados na avaliação estatística (Tabela 5). Em muitas das amostras analisadas, foram obtidos resultados com número muito baixo de E. coli, o que inviabiliza uma comparação satisfatória . 
Tabela 5. Dados obtidos na contagem de coliformes fecais e Escherichia coli pelos métodos convencional (NMP - tubos múltiplos), Petrifilm ${ }^{\circledR} \mathrm{EC} \quad \mathrm{e}$ Simplate ${ }^{\circledR} \mathrm{CEc}$.

\begin{tabular}{ccccc}
\hline Coleta & $\begin{array}{c}\text { Tubos múltiplos } \\
\text { Coliformes fecais }\end{array}$ & $\begin{array}{c}\text { Tubos múltiplos } \\
E . \text { coli } \\
\text { NMP } / \mathrm{mL}\end{array}$ & $\begin{array}{c}\text { Petrifilm }{ }^{\circledR} \mathrm{EC} \\
E . \text { coli } \\
\text { UFC/mL }\end{array}$ & $\begin{array}{c}\text { Simplate }{ }^{\circledR} \mathrm{CEc} \\
E . \text { coli } \\
\mathrm{NMP} / \mathrm{mL}\end{array}$ \\
\hline 1 & $<0,3$ & $<0,3$ & $<10^{2^{*}}$ & $<10^{2^{*}}$ \\
2 & $<0,3$ & $<0,3$ & $<10^{2^{*}}$ & $<10^{2^{*}}$ \\
3 & $<0,3$ & $<0,3$ & $<10^{2^{*}}$ & $<10^{2^{*}}$ \\
4 & $<0,3$ & $<0,3$ & $<10^{2^{*}}$ & $<10^{2^{*}}$ \\
5 & $0,04 \times 10$ & $0,04 \times 10$ & $<10^{2^{*}}$ & $<10^{2^{*}}$ \\
6 & $<0,3$ & $<0,3$ & $1,00 \times 10^{3}$ & $<10^{2 *}$ \\
7 & $1,50 \times 10^{2}$ & $1,50 \times 10^{2}$ & $<10^{3}$ & $7,00 \times 10^{2}$ \\
8 & $<0,3$ & $<0,3$ & $<10^{2^{*}}$ & $<10^{2^{*}}$ \\
9 & $<0,3$ & $<0,3$ & $6,35 \times 10^{4}$ & $9,80 \times 10^{4}$ \\
10 & $<0,3$ & $<0,3$ & $<10^{3}$ & $<10^{2^{*}}$ \\
11 & $0,03 \times 10$ & $0,03 \times 10$ & $1,00 \times 10^{2}$ & $2,00 \times 10^{2}$ \\
12 & $4,60 \times 10^{3}$ & $1,50 \times 10^{3}$ & $1,15 \times 10^{3}$ & $3,10 \times 10^{3}$ \\
13 & $2,40 \times 10^{2}$ & $0,53 \times 10$ & $1,00 \times 10^{2}$ & $<10^{2}$ \\
14 & $2,80 \times 10^{2}$ & $2,80 \times 10^{2}$ & $<10^{3}$ & $<10^{2 *}$ \\
15 & $<0,3$ & $<0,3$ & $<10^{3}$ & $1,00 \times 10^{2}$ \\
16 & $2,30 \times 10^{4}$ & $0,03 \times 10$ & $3,00 \times 10^{2}$ & $2,00 \times 10^{2}$ \\
17 & $4,30 \times 10^{2}$ & $4,30 \times 10^{2}$ & $2,00 \times 10^{2}$ & $3,00 \times 10^{2}$ \\
18 & $4,60 \times 10$ & $4,60 \times 10$ & $<10^{3}$ & $3,00 \times 10^{2}$ \\
19 & $2,10 \times 10^{2}$ & $2,10 \times 10^{2}$ & $<10^{4}$ & $5,00 \times 10^{2}$ \\
20 & $0,39 \times 10$ & $0,39 \times 10$ & $<10^{3}$ & $1,00 \times 10^{2}$ \\
21 & $0,43 \times 10$ & $0,43 \times 10$ & $<10^{2 *}$ & $<10^{2^{*}}$ \\
22 & $2,30 \times 10^{5}$ & $2,30 \times 10^{5}$ & $1,10 \times 10^{5}$ & $1,00 \times 10^{5}$ \\
23 & $0,61 \times 10$ & $0,61 \times 10$ & $1,00 \times 10^{4}$ & $9,40 \times 10^{3}$ \\
24 & $1,50 \times 10$ & $1,50 \times 10$ & $<10^{2^{*}}$ & $<10^{2^{*}}$ \\
25 & $1,50 \times 10^{2}$ & $1,50 \times 10^{2}$ & $1,40 \times 10^{3}$ & $1,50 \times 10^{3}$ \\
26 & $2,10 \times 10^{2}$ & $2,10 \times 10^{2}$ & $3,00 \times 10^{2}$ & $8,00 \times 10^{2}$ \\
27 & $9,30 \times 10^{2}$ & $9,30 \times 10^{2}$ & $1,50 \times 10^{2}$ & $8,00 \times 10^{2}$ \\
\hline & & & & \\
\hline
\end{tabular}

*As diluições empregadas nas análises de coliformes para os métodos Petrifilm ${ }^{\circledR} E C$ e Simplate ${ }^{\circledR} \mathrm{CEc}$ foram estabelecidas de acordo com testes preliminares, levando-se em conta a contagem de coliformes totais, já que as placas Petrifilm ${ }^{\circledR} \mathrm{EC}$ seriam incubadas numa única temperatura $\left(32^{\circ} \mathrm{C}\right)$. Foram empregadas diluições iguais e superiores a $10^{-2}$. 
No Petrifilm ${ }^{\circledR}$ EC, a leitura dos resultados de coliformes foi realizada após $24 \mathrm{~h}$ (coliformes totais) e 48h (para a contagem definitiva de colônias de E. coli). De acordo com recomendações de uso do sistema, as colônias típicas de E. coli dispensam confirmação por métodos convencionais e devem ser contadas como E. coli. No entanto, todas as colônias características de E. coli que foram isoladas das placas Petrifilm ${ }^{\circledR} \mathrm{EC}$ e submetidas à análise convencional foram confirmadas como E. coli. Das placas Petrifilm ${ }^{\circledR} E C$ analisadas, em nenhuma foi observado crescimento de E. coli após o período adicional de $24 \mathrm{~h}$ de incubação. Em algumas placas foi verificado crescimento de uma ou duas colônias de coliforme não E. coli, por placa, após o período de $48 \mathrm{~h}$, porém, isso não ocorreu para todas as amostras analisadas, o que sugere que o período de incubação de $24 \mathrm{~h}$ é adequado para análise de coliformes totais.

Não se pode afirmar se um método é mais sensível do que outro, apesar de algumas vezes um método ter recuperado $E$. coli e outro método não. Por exemplo, nas amostras 6 e 13, o Petrifilm ${ }^{\circledR} \mathrm{EC}$ detectou $E$. coli enquanto o SimPlate ${ }^{\circledR} \mathrm{CEc}$ não detectou. Já as contagens de E. coli nas amostras 9, 11, 12, 17, 25, 26 e 27 foram maiores no SimPlate ${ }^{\circledR} \mathrm{CEc}$ do que no Petrifilm ${ }^{\circledR}$ EC. Ainda, as amostras 1, 2, 3, 4 e 8 foram negativas para $E$. coli pelos três métodos utilizados (Tabela 5). Dois resultados da mesma tabela chamam atenção: nas amostras 9 e 23, os resultados de E. coli obtidos pelos métodos alternativos foram bem maiores do que pelo método convencional. Para essas amostras, os resultados compatíveis encontrados em SimPlate ${ }^{\circledR} \mathrm{CEc}$ e Petrifilm ${ }^{\oplus} \mathrm{EC}$, ambos bem superiores ao método convencional, mostram que a recuperação de E. coli, foi maior nos métodos alternativos. Apesar de poucas amostras, esses resultados concordam com a observação de Beloti (2000), de que os métodos convencionais podem ser menos sensíveis que os sistemas alternativos a eles comparados.

Em todas as amostras analisadas, pelo método convencional, que apresentaram coliformes fecais, a bactéria $E$. coli esteve presente (Tabela 5). Foi constatado que, para o leite cru analisado, devido à alta contaminação por coliformes totais (não E. coli) e flora acompanhante, nem sempre se consegue, numa mesma placa Petrifilm ${ }^{\circledR} \mathrm{EC}$, 
incubada na temperatura apropriada para coliformes totais, ter um número adequado de coliformes totais e E. coli para contagem, separadamente. Isso ocorre porque nas placas inoculadas com baixas diluições, as colônias de coliformes totais (não E. coli) e das bactérias da flora acompanhante atrapalham muito a visualização das colônias azuis de E. coli. Nessas condições o que se vê, muitas vezes, são manchas azuladas, sugerindo a presença da E. coli. As colônias dessa bactéria aparecem em menor número do que os coliformes totais, portanto, as diluições que são adequadas para contagem de E. coli geralmente são impróprias, ou muito baixas, para a contagem de coliformes totais.

Para uma comparação adequada de enumeração de $E$. coli entre os métodos, seria necessário partir de amostras não diluídas nos três métodos. Porém, em placas Petrifilm ${ }^{\circledR} \mathrm{EC}$, nas amostras não diluídas ou de baixa diluição, não seria possível fazer a contagem, a menos que as placas fossem incubadas em temperatura de $44^{\circ} \mathrm{C}$, conforme a recomendação de Franco (1994). Utilizando-se a temperatura como fator de seletividade, seria possível enumerar exclusivamente as colônias de E. coli.

Em placas Petrifilm ${ }^{\circledR}$ EC cujo número de coliformes é próximo de 150 e a microflora acompanhante muito alta, foi observada dificuldade de se fazer uma contagem precisa. Nesses casos, não se consegue ter certeza de que as bolhas de gás formadas sejam de uma ou de outra colônia. Hajdenwurcel \& Souza (1998) também relatam esse inconveniente das placas Petrifilm ${ }^{\circledR} \mathrm{EC}$ ao compará-las com SimPlate ${ }^{\circledR} \mathrm{CEc}$, e convencionais (VRB e NMP) para contagem de coliformes totais e $E$. coli em leite cru. Bailey \& Cox (1987) descrevem a difículdade de visualização das bolhas de gás aprisionadas ao redor das colônias de coliformes nas placas Petrifilm ${ }^{\circledR}$ durante avaliação microbiológica de carcaças de frango, nas quais os coliformes totais representavam menos de $10 \%$ do total da flora. Relatos sobre a dificuldade de enumeração de colônias de coliformes na presença de carga elevada de flora acompanhante em carne crua moída congelada também são feitos por Restaino \& Lyon (1987). É importante ressaltar que, quando se trabalha com diluições que possibilitem a visualização das colônias típicas, a contagem de coliformes nas placas Petrifilm ${ }^{\circledR} \mathrm{EC}$ é feita com grande facilidade e nitidez e não deixa dúvidas. 
Nelson et al. (1984), também trabalhando com leite cru, reportam que as contagens de coliformes obtidas em Petrifilm ${ }^{\circledR}$ foram equivalentes às obtidas em VRBA, e inferiores àquelas obtidas pela técnica convencional dos tubos múltiplos. Considerou os resultados equivalentes nos três métodos e concluiu que o Petrifilm ${ }^{\circledR}$ é uma alternativa viável aos métodos convencionais. No presente estudo, maiores contagens de coliformes foram obtidas pela técnica do NMP tubos múltiplos na maior parte das amostras, quando comparadas ao Petrifilm ${ }^{\circledR}$ EC (20 de 27 amostras, conforme Tabela 3), mas a análise estatística mostrou equivalência entre os métodos. Sobre esse aspecto, Jay (1998) esclarece que os resultados do NMP obtidos por tubos múltiplos são geralmente maiores do que aqueles das contagens de colônias em placas. Bishop \& Juan (1988), analisando coliformes em leite bovino cru, também encontraram bons parâmentros estatísticos na comparação entre Petrifilm ${ }^{\circledR}$ e convencional: $r=0,963$; inclinação da reta 1,017 e intercepto com eixo $y=-0,024$.

Piton \& Grappin (1991) apresentaram um modelo estatístico para avaliação dos métodos Petrifilm ${ }^{\circledR}$ para contagem de aeróbios mesófilos e coliformes em leite cru em comparação com os métodos convencionais. No referido estudo houve participação de 14 laboratórios e foi concluído que o Petrifilm ${ }^{\circledR}$ apresentou performance satisfatória mostrando forte correlação com as técnicas de referência. Entretanto, observaram que os resultados do número de coliformes obtidos em Petrifim ${ }^{\circledR}$ foram bem superiores aos encontrados pelo método convencional (VRBA). Os autores recomendam que seus resultados sejam analisados com cautela devido ao pequeno número de amostras analisadas/laboratório e incertezas sobre resultados de alguns laboratórios.

Segundo Curiale et al. (1991), em estudo colaborativo referente à validação das placas Petrifilm ${ }^{\circledR}$ para contagem de coliformes totais e E. coli para alimentos em geral, foram analisados queijos, farinhas, nozes, carne cozida com molho, cogumelos frescos e carne crua de peru, artificialmente contaminados. Os resultados nas placas Petrifilm ${ }^{\circledR}$ e na técnica do número mais provável (NMP) foram considerados comparáveis, sendo a reprodutibilidade da técnica Petrifïm ${ }^{\circledR}$ tão boa ou melhor do que a observada na técnica 
do NMP, o que resultou na sua aprovação pela AOAC (AOAC first action, method 991.14).

Quanto ao SimPlate ${ }^{\circledR} \mathrm{CEc}$, são poucas as referências na literatura especializada de comparação entre os resultados deste método com o convencional utilizado nesta pesquisa. Concordando com os resultados encontrados neste estudo, porém analisando vários tipos de alimentos, Townsend et al. (1998) encontraram bons parâmetros estatísticos na comparação do SimPlate ${ }^{\circledR}$ CEc com o método convencional: coeficiente de correlação variando de 0,86 a 0,98 ; inclinação da reta entre 0,91 e 1,02 e intercepto de 0,02 a 0,14 .

Quando comparações entre os sistemas Petrifilm ${ }^{\circledR} \mathrm{EC}$, SimPlate ${ }^{\circledR} \mathrm{CEc} \mathrm{e}$ convencionais são feitas a partir de análises de leite pasteurizado, coeficientes de correlação inferiores aos verificados no presente estudo são encontradas na literatura. Tavolaro et al. (1999), analisando leite de cabra pasteurizado e congelado obtiveram $r=$ 0,649, entre o método convencional de contagem de coliformes em placas e o SimPlate ${ }^{\circledR}$ CEc. O valor de $r$ entre o método convencional e o Petrifilm ${ }^{\circledR}$ foi de 0,726 . Também com leite pasteurizado, porém bovino, dentre os sistemas alternativos utilizados para enumeração de coliformes em NMP, Beloti (2000) encontrou a melhor correlação quando comparou o sistema ColiSure ${ }^{\circledR}$ com leitura em $48 \mathrm{~h}$ e CVBLB (0,8021). Comparando CVBLB com o Petrifilm ${ }^{\circledR} \mathrm{EC}$ encontrou $r=0,7375$ e 0,7123 para leituras em 48 e $24 \mathrm{~h}$, respectivamente. Não verificou correlação entre os resultados obtidos em SimPlate ${ }^{\circledR}$ CEc e em CVBLV. O autor porém, destaca pontos importantes: o leite analisado não foi inoculado e as contagens de coliformes no leite pasteurizado foram baixas e que o pequeno intervalo obtido entre os resultados torna a análise estatística mais severa. Observou que os métodos convencionais podem ser menos sensíveis e mais imprecisos do que os sistemas alternativos a eles comparados. Considerou os sistemas Petrifilm ${ }^{\circledR} \mathrm{EC}$ e ColiSure ${ }^{\circledR}$ alternativas viáveis aos métodos padrões.

Para análise de tilápias, Muratori et al. (2000) utilizaram os métodos convencional (NMP), Petrifilm ${ }^{\circledR}$ EC e SimPlate ${ }^{\circledR}$ CEc para identificação do grupo 
coliforme. Para coliformes totais, a análise estatística revelou diferença significativa entre os três métodos. Para $E$. coli não houve diferença estatística entre o Petrifilm ${ }^{\circledR} \mathrm{e}$ tubos múltiplos, porém foi significativa para o método Simplate ${ }^{\circledR}$. Os valores médios obtidos em SimPlate ${ }^{\circledR}$ foram maiores do que os obtidos pelos dois outros métodos.

Com leite cru, para coliformes totais, Hajdenwurcel \& Souza (1998) encontraram um coeficiente de correlação igual a 0,886 para Simplate ${ }^{\circledR}$ CEc x VRB. Para o Simplate ${ }^{\circledR}$ CEc x Petrifim ${ }^{\circledR}$ EC, $\quad r=0,943$, semelhante ao encontrado neste estudo. De acordo com os autores, devido à falta de precisão da contagem pelo NMP convencional, os resultados obtidos em Simplate ${ }^{\circledR} \mathrm{CEc}$, Petrifilm ${ }^{\circledR} \mathrm{EC}$ e contagem em placas (VRB) diferiram bastante quando comparados ao NMP determinado por tubos múltiplos. Valores de $r=0,640$ e 0,549 foram calculados para o método Petrifilm ${ }^{\circledR} \mathrm{EC} \times$ convencional (NMP) e SimPlate ${ }^{\circledR}$ CEc $x$ convencional (NMP), respectivamente, ambos bem inferiores aos observados nesta pesquisa (Tabela 4).

Para a contagem de coliformes totais, tanto o Petrifilm ${ }^{\circledR} \mathrm{EC}$ como o SimPlate ${ }^{\circledR} \mathrm{CEc}$ permitem leitura de resultados em $24 \mathrm{~h}$, com grande praticidade.

Para enumeração de E. coli em leite cru, o Petrifilm ${ }^{\circledR} \mathrm{EC}$ apresenta o inconveniente da dificuldade ou impossibilidade de contagem de colônias de $E$. coli em diluições baixas, quando o número de coliformes (não $E$. coli) e bactérias da flora acompanhante é elevado. Portanto, a contagem de E. coli e coliformes totais numa mesma placa Petrifilm ${ }^{\circledR}$ EC nem sempre é possível, sendo necessária a utilização de temperatura diferenciada, como fator de seletividade. Além disso, o Petrifilm ${ }^{\circledR} \mathrm{EC}$ necessita de um período de incubação de $48 \mathrm{~h}$ para resultados de $E$. coli.

Para a contagem de $E$. coli, o SimPlate ${ }^{\circledR} \mathrm{CEc}$ apresenta vantagens sobre os outros métodos, pois necessita de apenas $24 \mathrm{~h}$ de incubação e não apresenta interferência de outras bactérias na leitura dos resultados, pelo menos visualmente, por se tratar de reação enzimática, mesmo em diluições baixas. No leite cru analisado, foi possível observar que o SimPlate ${ }^{\circledR} \mathrm{CEc}$ foi o método que apresentou maior facilidade na leitura dos resultados de contagem de E. coli, independente da diluição empregada. 


\section{CONCLUSÕES}

O leite utilizado nas análises, naturalmente contaminado, reflete as condições reais de um laboratório de controle de qualidade de leite cru. O presente estudo fornece resultados que confirmam muitos dos resultados relatados com o sistema Petrifilm ${ }^{\circledR}$. Com respeito ao SimPlate ${ }^{\circledR}$, contribui com novos dados para a avaliação desse novo método de análise disponível no mercado brasileiro.

Os resultados permitem concluir que:

1) Para enumeração de microrganismos aeróbios mesófilos totais em leite cru, os resultados obtidos pelos métodos alternativos Petrifilm ${ }^{\circledR}$ AC e SimPlate ${ }^{\circledR}$ TPC foram equivalentes aos do plaqueamento convencional. Esses métodos alternativos podem ser adotados com vantagens nas análises de rotina da indústria.

2) Para análise de coliformes totais em leite cru, os métodos Petrifilm ${ }^{\circledR} \mathrm{EC}$ e Simplate ${ }^{\circledR} \mathrm{CEc}$ também apresentaram resultados compatíveis com o método convencional (tubos múltiplos), podendo ser usados como alternativas viáveis, muito mais práticas e rápidas nas análises microbiológicas de leite cru.

3) Para a enumeração de E. coli não foi possível uma análise estatística comparando os resultados obtidos pelos métodos alternativos com o convencional. Porém, foi possível observar que o Simplate ${ }^{\circledR} \mathrm{CEc}$ foi o método que apresentou maior facilidade na leitura de resultados. Para leite cru, a contagem de E. coli e coliformes totais numa mesma placa 
Petrifilm ${ }^{\circledR} \mathrm{EC}$ nem sempre é possível, sendo necessária a utilização de temperatura diferenciada, como fator de seletividade. 
ANEXOS 
ANEXO A - Método SimPlate ${ }^{\circledR}$ de alcance normal para determinação do número mais provável de microrganismos (NMP) por grama ou mililitro de alimento.

\begin{tabular}{|cccccc|}
\hline $\begin{array}{c}\text { Cavidades } \\
\text { Positivas }\end{array}$ & NMP & $\begin{array}{c}\text { Cavidades } \\
\text { Positivas }\end{array}$ & NMP & $\begin{array}{c}\text { Cavidades } \\
\text { Positivas }\end{array}$ & NMP \\
\hline 1 & 2 & 29 & 70 & 57 & 190 \\
2 & 4 & 30 & 74 & 58 & 196 \\
3 & 6 & 31 & 76 & 59 & 202 \\
4 & 8 & 32 & 80 & 60 & 208 \\
5 & 10 & 33 & 84 & 61 & 216 \\
6 & 12 & 34 & 86 & 62 & 224 \\
7 & 14 & 35 & 90 & 63 & 232 \\
8 & 16 & 36 & 94 & 64 & 240 \\
9 & 18 & 37 & 96 & 65 & 248 \\
10 & 22 & 38 & 100 & 66 & 256 \\
11 & 24 & 39 & 104 & 67 & 266 \\
12 & 26 & 40 & 108 & 68 & 276 \\
13 & 28 & 41 & 112 & 69 & 288 \\
14 & 30 & 42 & 116 & 70 & 298 \\
15 & 32 & 43 & 120 & 71 & 312 \\
16 & 36 & 44 & 124 & 72 & 324 \\
17 & 38 & 45 & 128 & 73 & 338 \\
18 & 40 & 46 & 132 & 74 & 354 \\
19 & 42 & 47 & 136 & 75 & 372 \\
20 & 46 & 48 & 142 & 76 & 392 \\
21 & 48 & 49 & 146 & 77 & 414 \\
22 & 50 & 50 & 150 & 78 & 440 \\
23 & 54 & 51 & 156 & 79 & 470 \\
24 & 56 & 52 & 160 & 80 & 508 \\
25 & 58 & 53 & 166 & 81 & 556 \\
26 & 62 & 54 & 172 & 82 & 624 \\
27 & 64 & 55 & 178 & 83 & 738 \\
28 & 68 & 56 & 184 & 84 & $>738$ \\
\hline
\end{tabular}

Fonte: BioControl Systems 
ANEXO B - Certificados de aprovação do SimPlate ${ }^{\circledR}$ TPC pela AOAC. 63/65/97 20:49 AOAC INTERNATIONAL. + 2078560346

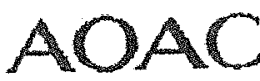

RESEARCH INSTITUTE
$4 K 1 \wedge$ Frederick ave, Suite $S 00$

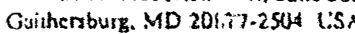

$+1-(301) \cdot 8267000(T-1)$ +1 (301)-3.4-7089 rax

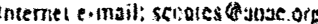

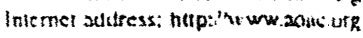

\title{
Certificate of \\ Performance Tested \\ Status
}

Certificate No. 970301

The AOAC Research Institute hereby certifies that the performance of the test kit designatei as:

\author{
SimPlate ${ }^{m}$ for TPC \\ momufactured by
}

IDEXX Laboratorics, Inc

One Idexx Drive

Westbrook, Me. 04092

\begin{abstract}
hes been reviewed under the AOAC Restanch Instiure's Perfomence Testegos Program, and found to perions as

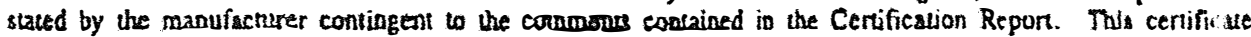
atuhorizas the manufacturer to display the AOAC Pefromance Tested certificarion mark al ong with the staterstat - "TKIS TEST KIT ' PERFORMANCE WAS REVIEWED BY AOAC RESEARCH NISTTTUTE AND WAS FOUND TO PRRFORM TO THE MANUFACTURER'S SPECIFICATION5" - on the above mentioned test kit for a period of oxc year from the date of this certificase. Renewal may be gransed at the end of cae ycar under the riles stated in the licensing agreemem.
\end{abstract}

Siguod for AOAC Rescasch Institule

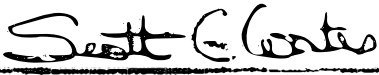

Seon G. Costes

Mansging Dirrecour

March 5. 1997 


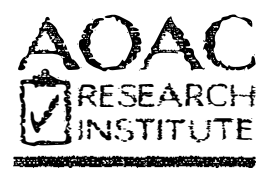

AOAC Research Institute

481 N. Frederick Avis, Suite 500

Gaithersburg, MD :0877-2417

Telephone: $+1 \cdot 30 \cdot-924-7090$ Fax: $+1-30 \div-924-7089$

\title{
Certificate of Performance Tested ${ }^{k}$ \\ Status
}

\section{Certificate No. 970301}

The AOAC Research Institute hereby certifies that the performance of the test kit designatec as:

\author{
SimPlate for TPC \\ manufactured by \\ BioControl Systems \\ 12822 SE $32^{\text {nd }}$ Street \\ Bellevue, WA 98005
}

has been reviewed under the AOAC Research Institule's Performance Tested Methods K Progran, and found to perform as stated by the manufacturer contingent to the comments convined in the Certification Report. This certificate author izes the manufacturer to display the AOAC Performance Tested $\mathbf{K}$ certification mark along with the staternent - "THIS TIST KIT'S PERFORMANCE WAS REVIEWED BY AOAC RESEARCH INSTITUTE AND WAS FOUND TO PERFORM T THE MANUFACTURER'S SPECIFICATIONS" - on the above mentioned test kit for a period of :ne year from the date of this certificate (January 1, 2001 - December 31, 2001). Renewal may be granted at the end of one year under the rules stated in the licensing agreement.

Signed for AOAC Research Institute:

\section{Scott Cotes}

Scott G. Coates

Managing Director 
ANEXO C - Número mais provável para várias combinações de resultados positivos, quando três tubos são usados por diluição (inoculação de 1,$0 ; 0,1$ e $0,01 \mathrm{~g}$ ou mL de amostra).

\begin{tabular}{|c|c|c|c|c|c|c|c|}
\hline \multicolumn{4}{|c|}{ Combinação de tubos positivos } & \multicolumn{4}{|c|}{ Combinação de tubos positivos } \\
\hline $1,0 \mathrm{~g}$ & $0,1 \mathrm{~g}$ & $\mathbf{0 , 0 1 g}$ & NMP & $1,0 \mathrm{~g}$ & $\mathbf{0 , 1 g}$ & $0,01 \mathrm{~g}$ & NMP \\
\hline 0 & 0 & 0 & $<0,3$ & 2 & 0 & 0 & 0,91 \\
\hline 0 & 0 & 1 & 0,3 & 2 & 0 & 1 & 1,4 \\
\hline 0 & 0 & 2 & 0,6 & 2 & 0 & 2 & 2,0 \\
\hline 0 & 0 & .3 & 0,9 & 2 & 0 & 3 & 2,6 \\
\hline 0 & 1 & 0 & 0,3 & 2 & 1 & 0 & 1,5 \\
\hline 0 & 1 & 1 & 0,61 & 2 & 1 & 1 & 2,0 \\
\hline 0 & 1 & 2 & 0,92 & 2 & 1 & 2 & 2,7 \\
\hline 0 & 1 & 3 & 1,2 & 2 & 1 & 3 & 3,4 \\
\hline 0 & 2 & 0 & 0,62 & 2 & 2 & 0 & 2,1 \\
\hline 0 & 2 & 1 & 0,93 & 2 & 2 & 1 & 2,8 \\
\hline 0 & 2 & 2 & 1,2 & 2 & 2 & 2 & 3,5 \\
\hline 0 & 2 & 3 & 1,6 & 2 & 2 & 3 & 4,2 \\
\hline 0 & 3 & 0 & 0,94 & 2 & 3 & 0 & 2,9 \\
\hline 0 & 3 & 1 & 1,3 & 2 & 3 & 1 & 3,6 \\
\hline 0 & 3 & 2 & 1,6 & 2 & 3 & 2 & 4,4 \\
\hline 0 & 3 & 3 & 1,9 & 2 & 3 & 3 & 5,3 \\
\hline 1 & 0 & 0 & 0,36 & 3 & 0 & 0 & 2,3 \\
\hline 1 & 0 & 1 & 0,72 & 3 & 0 & 1 & 3,9 \\
\hline 1 & 0 & 2 & 1,1 & 3 & 0 & 2 & 6,4 \\
\hline 1 & 0 & 3 & 1,5 & 3 & 0 & 3 & 9,5 \\
\hline 1 & 1 & 0 & 0,73 & 3 & 1 & 0 & 4,3 \\
\hline 1 & 1 & 1 & 1,1 & 3 & 1 & 1 & 7,5 \\
\hline 1 & 1 & 2 & 1,5 & 3 & 1 & 2 & 12 \\
\hline 1 & 1 & 3 & 1,9 & 3 & 1 & 3 & 16 \\
\hline 1 & 2 & 0 & 1,1 & 3 & 2 & 0 & 9,3 \\
\hline 1 & 2 & 1 & 1,5 & 3 & 2 & 1 & 15 \\
\hline 1 & 2 & 2 & 2,0 & 3 & 2 & 2 & 21 \\
\hline 1 & 2 & 3 & 2,4 & 3 & 2 & 3 & 29 \\
\hline 1 & 3 & 0 & 1,6 & 3 & 3 & 0 & 24 \\
\hline 1 & 3 & 1 & 2,0 & 3 & 3 & 1 & 46 \\
\hline 1 & 3 & 2 & 2,4 & 3 & 3 & 2 & 110 \\
\hline 1 & 3 & 3 & 2,9 & 3 & 3 & 3 & $>110$ \\
\hline
\end{tabular}

Fonte: ABNT (1991)

Nota: Os valores de NMP são calculados partindo-se de porções iniciais de $1 \mathrm{~g}$ ou $\mathrm{mL}$ de amostra. 


\section{ANEXO D}

Tabela 6. Análise de Variância e Teste F para contagem total de aeróbios mesófilos.

\begin{tabular}{ccccc}
\hline $\begin{array}{c}\text { Causa de } \\
\text { variação }\end{array}$ & $\begin{array}{c}\text { Graus de } \\
\text { liberdade }\end{array}$ & $\begin{array}{c}\text { Soma dos } \\
\text { quadrados }\end{array}$ & Quadrado médio & Teste F \\
\hline Blocos & 29 & 39,9382 & & \\
Métodos & 2 & 0,0050 & 0,0025 & $0,30^{\text {ns }}$ \\
Resíduo & 58 & 0,4868 & 0,0084 & \\
Total & 89 & 40,4301 & & \\
\hline
\end{tabular}

ns = não significativo

* = significativo ao nível de $1 \%$ de probabilidade

Tabela 7. Análise de Variância e Teste F para contagem total coliformes totais.

\begin{tabular}{ccccc}
\hline $\begin{array}{c}\text { Causa de } \\
\text { variação }\end{array}$ & $\begin{array}{c}\text { Graus de } \\
\text { liberdade }\end{array}$ & $\begin{array}{c}\text { Soma dos } \\
\text { quadrados }\end{array}$ & Quadrado médio & Teste F \\
\hline Blocos & 26 & 62,3579 & & \\
Métodos & 2 & 0,2258 & 0,1129 & $4,11^{\text {ns }}$ \\
Resíduo & 52 & 1,4295 & 0,0274 & \\
Total & 80 & 64,0133 & & \\
\hline
\end{tabular}

ns = não significativo

* = significativo ao nível de $1 \%$ de probabilidade 


\section{REFERÊNCIAS BIBLIOGRÁFICAS}

AGÊNCIA NACIONAL DE VIGILÂNCIA SANITÁRIA. Resolução RDC $\mathbf{n}^{\mathbf{0}} \mathbf{1 2}$, de $\mathbf{2}$ de janeiro de 2001. http://www.anvisa.gov.br/legis/resol/12_01 rdc.htm (02 mar. 2002)

ALEIXO, J.A.; AVER, G.P. Prevalence of enteropathogenic and enterotoxigenic Escherichia coli in foods of animal origin in southern Brasil. Ciência Rural, v.26, n.2, p.247-250, 1996.

AMERICAN PUBLIC HEALTH ASSOCIATION. Standard methods for the examination of dairy products. 16.ed. Washington: APHA, 1992. 546p.

ASSOCIAÇÃO BRASILEIRA DE NORMAS TÉCNICAS - MB 3463. Bactérias coliformes totais, coliformes fecais e Escherichia coli em alimentos: determinação pelo número mais provável (NMP). Rio de Janeiro, 1991. 7p.

ASSOCIATION OF OFFICIAL ANALYTICAL CHEMISTRY - AOAC. Method validation programs. http://www.aoac.org (27 jan. 2002)

BAILEY, J.S.; COX, N.A. Evaluation of the Petrifilm SM and VRB dry media culture plates for determining microbial quality of poultry. Journal of Food Protection, v.50, n.8, p.643-644, 1987. 
BEAUCHAT, L.R.; COPELAND, F.; CURIALE, M.S.; DANISAVICH, T.; GANGAR, V.; KING, B.W.; LAWLIS, T.L.; LIKIN, R.O.; OKWUSOA, J.; SMITH, C.F.; TOWNSEND, D.E. Comparison of the SimPlate ${ }^{T M}$ total plate count method with Petrifilm $^{\mathrm{TM}}$, Redigel ${ }^{\mathrm{TM}}$ and conventional pour-plate methods for enumerating aerobic microrganisms in foods. Journal of Food Protection, v.61, n. 1, p.14-18, 1998.

BELOTI, V. Fatores que podem influenciar o desempenho de métodos rápidos para enumeração de microrganismos indicadores de higiene em leite pasteurizado. São Paulo, 2000. 87p. Tese (Doutorado) - Faculdade de Ciências Farmacêuticas, Universidade de São Paulo.

BELOTI, V.; FRANCO, B.D.M.G.; BARROS, M.A.F.; NERO, L.A.; SOUZA, J.A.; SANTANA, E.H.W. Influência da microbiota do leite no desempenho do Petrifilm AC para enumeração de microrganismos aeróbios mesófílos. In: CONGRESSO BRASILEIRO DE MICROBIOLOGIA, 20., Salvador, 1999. Resumos. Salvador: Sociedade Brasileira de Microbiologia, 1999a. p.380.

BELOTI, V.; BARROS, M.A.F.; FREITAS, J.C.; NERO, L.A.; SOUZA, J.A.; SANTANA, E.H.W.; FRANCO, B.D.G.M. Frequency of 2,3,5Triphenyltetrazolium Chloride (TTC) non-reducing bacteria in pasteurized milk. Revista de Microbiologia, n.30, p.137-140, 1999 b.

BELOTI, V.; FRANCO, B.D.M.G.; BARROS, M.A.F.; NERO, L.A.; SOUZA, J.A.; SANTANA, E.H.W. Influência da qualidade do leite no desempenho do Petrifilm AC para enumeração de microrganismos aeróbios mesófilos. In: CONGRESSO BRASILEIRO DE MICROBIOLOGIA, 20., Salvador, 1999. Resumos. Salvador: Sociedade Brasileira de Microbiologia, 1999c. p.381. 
BELOTI, V.; BARROS, M.A.F.; NERO, L.A.; SOUZA, J.A.; SANTANA, E.H.W.; FRANCO, B.D.G.M. PetrifilmTM AC em leite pasteurizado: o porquê das contagens menores. Indústria de Laticínios, v.5, n.26, p.50, 2000.

BEHMER, M.L.A. Tecnologia do leite. 13.ed. São Paulo: Nobel, 1984. 320p.

BERGER, S.A. Increased protection afforded by the defined substrate technology Colilert system by its ability to detect Shigella $\beta$-glucuronidase. Letters in Applied Microbiology, v.19, n.1, p.53-56, 1994.

BIGALKE, D. Dairy quality. Dairy and Food Microbiology, v.4, n.3, p.114-115, 1984a.

BIGALKE, D. Dairy quality. Dairy and Food Microbiology, v.4, n.5, p.189-190, 1984b.

BISHOP, J.R.; JUAN, J. Improved methods for quality assessment of raw milk. Journ al of Food Protection, v.51, n.12, p.955-957, 1988.

BLACKBURN, C.W.; BAYLIS, C.L.; PETITT, S.B. Evaluation of Petrifilm ${ }^{\mathrm{TM}}$ methods for enumeration of aerobic flora and coliforms in a wide range of foods. Letters in Applied Microbiology, v.22, n.2, p.137-140, 1996.

BRAMLEY, A.J.; McKINNON, C.H. The microbiology of raw milk. In: ROBINSON, R.K. (Ed.). Dairy microbiology. New York: Elsevier Applied Science Publishers, 1990. cap.5, p.163-207.

BRASIL. Ministério da Agricultura. Lei $\mathbf{n}^{0} 30.691$ de 29 de março de 1952. http://www.agricultura.gov/br/sda/dipoa (05 jan. 2002) 
BRASIL. Ministério da Agricultura. Portaria n 56 de 07 de dezembro de 1999. http://www.agricultura.gov.br/sda/dipoa/port56.htm (15 dez. 2000)

BYRNE, R.D.; BISHOP, J.R. Evaluation of a dry medium culture plate (3M Petrifilm AC) for laboratory pasteurized counts. Journal of Food Protection, v.54, n.4, p.308-309, 1991.

CAMPREGHER, R.B. Utilização das metodologias convencional e simplate para avaliação das condições microbiológicas de suco de laranja pasteurizado e não pasteurizado. Piracicaba, 2000. 97p. Dissertação (Mestrado) - Escola Superior de Agricultura "Luiz de Queiroz", Universidade de São Paulo.

CARVALHO, C.M. de. Avaliação comparativa entre o teste de redutase e contagem de microrganismos aeróbios totais e coliformes totais por metodologia convencional e pelo sistema Petrifilm em leite cru refrigerado. Piracicaba, 2001. 65p. Dissertação (Mestrado) - Escola Superior de Agricultura "Luiz de Queiroz", Universidade de São Paulo.

CHAIN, V.S.; FUNG, D.Y.C. Comparison of Redigel, Petrifilm, Spiral Plate System, Isogrid, and aerobic Plate Count for determining the numbers of aerobic bacteria in selected foods. Journal of Food Protection, v.54, n.3, p.208-2 10, 1991.

CHAMPAGNE, C. P.; GOULET, J. Microbiología de la leche. In: AMINOT, J. (Ed.). Ciencia y tecnología de la leche. Zaragoza: Acribia, 1991. Cap.3, p.77-109.

CHRISTEN, G.L.; DAVIDSON, P.M.; McAlLISTER, J.S.; ROTH, L.A. Coliform and other indicator bacteria. In: MARSHALL, R.T. (Ed.). Standard methods for the examination of dairy products. Washington: American Public Health Association, 1992. Chap.7, p.247-269. 
COSTELLO, M.; DOUGHERTY, R.H.; KANG, D. The relationship between standard plate counts and coliform counts in raw milk. Dairy, Food and Environmental Sanitation, v.21, n.9, p.749-751, 2001.

CURIALE, M.S.; FAHEY, P.; FOX, T.L.; McALLISTER, J.S. Dry rehydratable films for enumeration of coliforms and aerobic bacteria in dairy products: collaborative study. Journal of Association of Official Analytical Chemists, v.72, n.2, p.312$325,1989$.

CURIALE, M.S.; SONS, T.; McALLISTER, J.S.; HALSEY, B.; FOX, T.L. Dry rehydratable film for enumeration of total aerobic bacteria in foods: collaborative study. Journal of Association of Official Analytical Chemists, v.73, n.2, p.242248, 1990.

CURIALE, M.S.; SONS, T.; McIVER, D.; McAlLISTER, J.S.; HALSEY, B.; ROBLEE, D.; FOX, T.L. Dry rehydratable film for enumeration of total coliforms and Escherichia coli in Foods: collaborative study. Journal of Association of Official Analytical Chemists, v.74, n.4, p.635-648, 1991.

CUTOLO, A.A.; PIRES, A.; JURKIEWICS, H.C. Avaliação do método SimPlate para contagem total de bactérias mesófilas em alimentos. In: CONGRESSO LATINOAMERICANO DE MICROBIOLOGIA E HIGIENE DE ALIMENTOS, 5., Águas de São Pedro, 1998. Resumos. São Paulo: Sociedade Brasileira de Microbiologia, 1998, res. M.1.3.

FONSECA, L.F.L.; PEREIRA, C.C.; CARVALHO, M.P. Qualidade microbiológica do leite. In: SIMPÓSIO INTERNACIONAL SOBRE PRODUÇÃO INTENSIVA DE LEITE, Caxambu, 1999. Anais. São Paulo: Instituto Fernando Costa, 1999. 118p. 
FRANCO, B.D.G.M. Métodos rápidos de análise microbiológica de alimentos: estudo crítico e avaliação de novas metodologias. São Paulo, 1994. 128p. Tese (LivreDocência) - Faculdade de Ciências Farmacêuticas, Universidade de São Paulo.

FRANCO, B.D.G.M. Novas técnicas de análise microbiológica de alimentos. Revista Nacional da Carne, n.230, p.59-65, 1996a.

FRANCO, B.D.G.M. Métodos de análise. In: FRANCO, B.D.G.M.; LANDGRAF, M. Microbiologia dos alimentos. São Paulo: Atheneu, 1996b. p.165-176.

FRANCO, B.D.G.M. Critérios microbiológicos para avaliação da qualidade de alimentos. In: FRANCO, B.D.G.M.; LANDGRAF, M. Microbiologia dos alimentos. São Paulo: Atheneu, 1996c. p.149-154.

FRANCO, B.D.G.M. Inovação nos métodos de análise microbiológica de leite e derivados. Indústria de Laticínios, v.3, n.18, p.70-71, 1998.

FRANCO, B.D.G.M. Métodos alternativos de análise microbiológica de alimentos. Boletim da SBCTA, v.33, n.2, p.229-234, 1999a.

FRANCO, B.D.G.M. Métodos modernos em microbiologia de leite e de derivados. Indústria de Laticínios, v.3, n.19, p.54-56, 1999b.

FRANCO, B.D.G.M; LANDGRAF, M; BRANCHER, I.; GOULARTE, L. Visão geral sobre novos métodos em microbiologia de alimentos. Boletim da Sociedade Brasileira de Ciência e Tecnologia de Alimentos, v.26, n.15, p.45-52, 1992.

FORSYTHE, S.J. Microbiologia da segurança alimentar. Porto Alegre: Artmed, 2002. $424 p$. 
GINN, R.E.; PACKARD, V.S.; FOX, T.L. Evaluation of the 3M dry medium culture plate (Petrifilm ${ }^{T M} \mathrm{SM}$ ) method for determining numbers of bacteria in raw milk. Journal of Food Protection, v.47, n. 10, p.753-755, 1984.

GINN, R.E.; PACKARD, V.S.; FOX, T.L. Evaluation of total bacteria and coliforms in milk by dry rehydratable film methods: collaborative study. Journal of Association of Official Analytical Chemists, v.69, n.3, p.527-531, 1986.

HAJDENWURCEL, J.R. Atlas de microbiologia de alimentos. São Paulo: Fonte Comunicações e Editora, 1998. 66p.

HAJDENWURCEL, J.R.; SOUZA, H.M. Avaliação do método SimPlate para contagem de coliformes totais e E. coli em leite fluido. Indústria de Laticínios, v.3, n.17, 1998.

HAYES, P.R. Microbiologia e higiene de los alimentos. Zaragoza: Acribia, 1993. Cap.8, p.229-249: Confirmación de la calidade y control de produción..

HAYES, M.C.; RALYEA, R.D.; MURPHY, S.C.; CAREY, N.R.; SCARLETT, J.M.; BOOR, K.J. Identification and characterization of elevated microbial counts in bulk tank raw milk. Journal of Dairy Science, v. 1, n.84, p. 292-298, 2001. / Resumo em WebSPIRS Abstracts on CD-ROM, 2001.

INTERNATIONAL COMMISSION ON MICROBIOLOGICAL SPECIFICATIONS FOR FOODS. Microorganisms in foods. 2.ed. Toronto: University of Toronto Press, 1978. v.1, 434p.

JAY, J.M. Modern food microbiology. 5.ed. New York: Chapman and Hall, 1996. $661 \mathrm{p}$. 
JAY, M.J. Modern food microbiology. 5.ed. Gaithersburg: Aspen Publishers, 1998. $661 \mathrm{p}$.

KORNACHI, J.L.; MARTH, E.H. Foodborne illness caused by Escherichia coli: a review. Journal of Food Protection, v.11, n.45, p.1051-67, 1982.

LANDGRAF, M. Microrganismos indicadores. In: FRANCO, B.D.G. de M.; LANDGRAF, M. Microbiologia dos alimentos. São Paulo: Atheneu, 1996. cap.3, p. 27-31.

LIMA, M. da C. Efeito de tratamentos térmicos do leite tipo $\mathrm{C}$ em grupos de microrganismos e em seu desenvolvimento e estocagem em diferentes temperaturas. Viçosa, 1988. 90p. Dissertação (Mestrado) - Universidade Federal de Viçosa.

MATNER, R.R.; FOX, T.L.; McIVER, D.E., CURIALE, M.S. Efficacy of the Petrifilm ${ }^{\mathrm{TM}}$ E. coli count plates for É.coli and coliform enumeration. Journal of Food Protection, v.53, n.2, p.145-150, 1990.

McALLISTER, J.S.; RAMOS, M.S.; FOX, T.L. Evaluation of the 3M dry medium culture plate (Petrifilm ${ }^{\mathrm{TM}} \mathrm{SM}$ ) method for enumerating bacteria in processed fluid milk samples. Journal of Food Protection, v.7, n.12, p.632-635, 1987.

McGREGOR, J.U.; TRAYLOR, S.M.; GOUGH, R.H.; HAZLETT, S.; BIRD, K. Recovery of lactic acid bacteria on Petrifilm ${ }^{\text {TMSM }}$ under various incubation atmopheres. Journal of Food Protection, v.57, n.3, p.316-318, 1995. 
MURATORI, M.C.S.; OLIVEIRA, A de L.; RIBEIRO, L.P.; COSTA, A.P.R.; FERNANDES, S.H.; LEITE, R.C. Comparación entre el método estándar sugerido por APHA y los métodos Simplate ${ }^{\circledR}$ y Petrifilm ${ }^{\circledR}$, para la identificación del grupo coliforme y de Escherichia coli en tilapia (Oreochromis sp) procedente de piscicultura de agua dulce. Revista Argentina de Microbiologia, n.32, p.15-19, 2000 .

MURPHY, S.C.; BOOR, K.J. Trouble-shooting sources and causes of high bacteria counts in raw milk. Dairy, Food and Environmental Sanitation, v.20, n.8, p.606$611,2000$.

NELSON, C.L.; FOX, T.L.; BUSTA, F.F. Evaluation of dry medium film (Petrifilm VRB) for coliform enumeration. Journal of Food Protection, v.47, n.7, p.520-525, 1984.

OLIVEIRA, A.F.A. de. Implantação do sistema HACCP (Análise de Perigos e Controle de Pontos Críticos). Indústria de Laticínios, v.6, n.35, p.56-61, 2001.

OLIVEIRA, J. S. Qualidade microbiológica do leite. Revista do Instituto de Laticínios Cândido Tostes, v.26, n. 220, p.16-22, 1976.

OLIVEIRA, A.J.; CARUSO, J.G.B. Leite: obtenção e qualidade do produto fluido e derivados. Piracicaba: FEALQ, 1996. 80p.

O'TOOLE, D.K. Methods for the direct and indirect assessment of the bacterial content of milk. Journal of Applied Bacteriology, v.55, n.2, p.187-201, 1983.

PELCZAR, M.J.; REID, R.; CHAN, E.C.S. Microbiologia. São Paulo: McGraw-Hill do Brasil, 1996. 2v. 
PITON, C.; GRAPPIN, R. A model for statistical evaluation of precision parameters of microbiological methods: application to dry rehydratable film method and IDF reference methods for enumeration of total aerobic mesophilic flora and coliforms in raw milk. Journal of Association of Official Analytical Chemists, v.74, n.1, p.92-103, 1991 .

PRATA, L.F.; FIGUEIRA, M.AD.T. Precisão da contagem total em Petrifilm na discriminação de limites em leite pasteurizado. In: CONGRESSO LATINOAMERICANO DE MICROBIOLOGIA E HIGIENE DE ALIMENTOS, 5., Águas de São Pedro, 1998. Resumos. São Paulo: Sociedade Brasileira de Microbiologia, 1998, res. M.4.3.

RAY, B. Fundamental food microbiology. New York: CRC Press, 1996. 516p.

REISTAINO, L.; LYON, R.H. Efficacy of PetrifilmTM VRB for enumerating coliforms and Escherichia coli from frozen raw beef. Journal of Food Protection. v.50, n.12, p.1017-1022, 1987.

RICHTER, R.L.; LEDFORD, R.A.; MURPHY, S.C. Milk and milk products. In: VANDERZANT, C.; SPLITTSTOESSES, D.F. (Ed.). Compendium of methods for the microbiological examination of foods. Washington: American Public Health Association, 1992. Chap.45, p.837-856.

RIEDEL, G. Controle sanitário dos alimentos. São Paulo: Edições Loyola, 1992. cap.10, p.173-175: Alimentos naturais.

ROITMAM, I.; TRAVASSOS, L.R.; AZEVEDO, J.L. (Ed.). Tratado de microbiologia. São Paulo: Manole, 1988. p.5-96. 
STATISTICAL ANALYSIS SYSTEM INSTITUTE. Sas/Qc software: usage and reference. 2.ed. Cary, 1996. 2v.

SEGURANÇA alimentar: o caminho para ganhar a confiança e fidelidade do consumidor. Indústria de Laticínios, n.35 p.12-27, 2001.

SHARPE, A.N. Aplicación de métodos microbiológicos rápidos en sistemas de producción de alimentos basados en el análisis de peligros potenciales y puntos críticos de control (HACCP). La Alimentación Latinoamericana, n.207, p.36-48, 1995.

SHULTZ, T.; COLlAR, L.; GUTERBOCK, W.; ESTEBAN, E. Milk quality. http://www.animalscience.ucdavis.edu/extension/dm/Tulare002.pdf (01 july 2002)

SILVA, N. da. Novos métodos de análise microbiológica de alimentos. Coletânea do Instituto de Tecnologia de Alimentos, v.26, n.1, p.1-13, 1996.

SILVA, N. da; JUNQUEIRA, V.C.A.; SILVEIRA, N.F.A. Manual de métodos de análise microbiológica de alimentos. São Paulo: Varela, 1997. 295p.

SILVA, N. da; NAKAZATO, L.T.; MIYAGUSKU, L. Avaliação do método de plaqueamento em gotas para contagem de microrganismos em alimentos. Coletânea do Instituto de Tecnologia de Alimentos, v.26, n.1, p.49-54, 1996.

SILVA, N. da; NETO, R.C.; JUNQUEIRA, V.C.A.; SILVEIRA, N.F.A. Manual de métodos de análise microbiológica da água. Campinas: ITAL, Núcleo de Microbiologia, 2000. 99p.

SIQUEIRA, R.S. Manual de microbiologia de alimentos. Brasília: EMBRAPA, SPI; Rio de Janeiro: EMBRAPA, CTAA, 1995. 159p. 
SMITH, C.F.; TOWNSEND, D.E. A new medium for determining the total plate count in food. Journal of Food Protection, v.62, n.12, p.1404-1410, 1999.

SWANSON, K.M.J.; BUSTA, F.F.; PETERSON, E.H.; HOHNSON, M.G. Colony count methods. In: VANDERZANT, C.; SPLITTSTOESSER, D. F. (Ed.). Compendium of methods for the microbiological examination of foods. Washington: American Public Health Association, 1992. Chap.4, p.75-95.

TAVOLARO, P. Avaliação de metodologias rápidas para a determinação da qualidade microbiológica e da vida de prateleira de leite de cabra pasteurizado e congelado. São Paulo, 2000. 90p. Dissertação (Mestrado) - Faculdade de Ciências Farmacêuticas, Universidade de São Paulo.

TAVOLARO, P.F.; RAMAZZOTTI, A.; FRANCO, B.D.G.M. Avaliação de métodos rápidos em microbiologia em leite de cabra pasteurizado e congelado. In: CONGRESSO BRASILEIRO DE MICROBIOLOGIA, 20., Salvador, 1999. Resumos. São Paulo: Sociedade Brasileira de Microbiologia, 1999.p.375.

TEIXEIRA, A.M.; MASSAGUER, P.R.; FERREIRA, E.C.; TOSELLO, R.M. Agilizando a contagem de bactérias em leite cru brasileiro. Indústria de Laticínios, v.4, n.25, p.46-49, 2000.

THIELMANN, C. Avaliação das características da qualidade e prazo de validade de leite tipo A. Viçosa, 1995. 127p. Dissertação (Mestrado) - Universidade Federal de Viçosa.

TORTORA, G.J.; FUNKE, B.R.; CASE, C.L. Microbiologia. Porto Alegre: Artmed, 2000, 827p. 
TOWNSEND, D.E.; NAQUI, A. Comparison of SimPlate total plate count test with agar method for detection and quantitation of bacteria in food. Journal of Association of Official Analytical Chemists, v.81, n.3, p.563-569, 1998.

TOWNSEND, D.E.; IRWING, R.L.; NAQUI, A. Comparison of SimPlate coliform and Escherichia coli Test with Petrifilm, three-tube NMP, and VRBA+MUG Methods for enumerating coliforms and E. coli in food. Journal of Food Protection, v.61, n.4, p.444-449, 1998.

VARGAS, O.L. A comercialição de leite cru e a segurança do consumidor. Revista do Instituto de Laticínios Cândido Tostes, v.50, n.291, p.3-17, 1995.

VARNAM, A.H.; SUTHERLAND, J. P. Milk and milk products. London: Chapman \& Hall, 1996. 451p.

VASAVADA, P.C.; CHANDLER, R.E.; HULL, R.R. Evolving methodologies for microbiological examination of milk and dairy foods. Dairy, Food and Environmental Sanitation, v.13, n.9, p.510-515, 1993.

WALLEN, S.E. Producing milk with a low bacteria count. Dairy and Food Sanitation, v.4, n.7, p.256-259, 1984.

ZALL, R.R.; CHEN, J.H.; MURPHY, S.C. Effect of a refrigerated milk receiver on raw milk quality. Dairy and Food Sanitation, v.3, n.11, p.408-414, 1983. 